\title{
Trace gas fluxes from soils and tree stems of rainforests and cacao agroforests in the Congo Basin, Cameroon
}

\author{
Dissertation zur Erlangung des Doktorgrades \\ der Fakultät für Forstwissenschaften und Waldökologie \\ der Georg-August-Universität Göttingen
}

vorgelegt von

NAJEEB AL-AMIN IDDRIS

geboren in Kumasi, Ghana

Göttingen, März 2020 
1. Gutachter: Professor Dr. Edzo Veldkamp

2. Gutachter: Professor Dr. Alexander Knohl

Tag der mündlichen Prüfung: 26.05.2020

PhD supervisors: Professor Dr. Edzo Veldkamp and Dr. Marife D. Corre 
Hasbunallahu Wa Ni'mal Wakeel

To my dad, Iddris Issah, who gave up his dreams so I could achieve mine, and to my supervisor, Marife D. Corre; "The scientist I am and hope to be I owe to her mentorship. 


\section{TABLE OF CONTENTS}

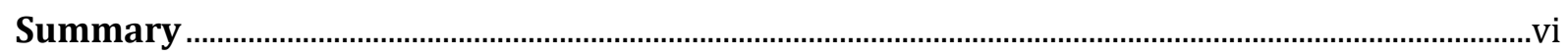

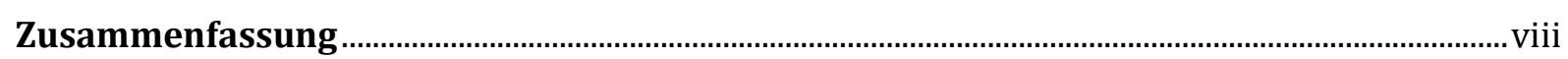

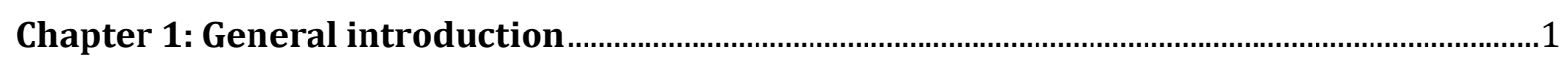

1.1. The role of the tropics in the global trace greenhouse gas budgets ...........................................

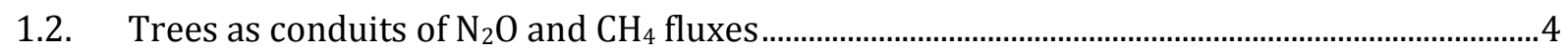

1.3. Effects of land-use change on trace gas fluxes............................................................................

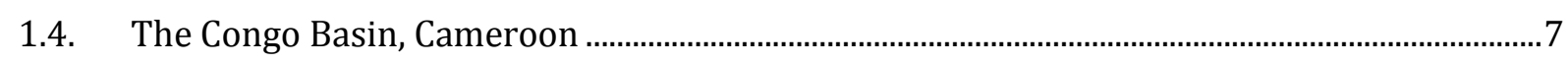

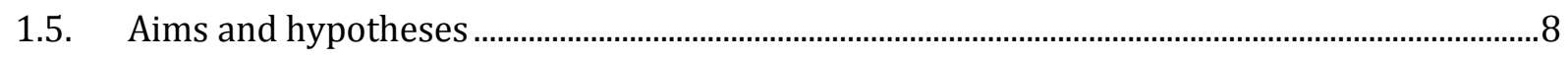

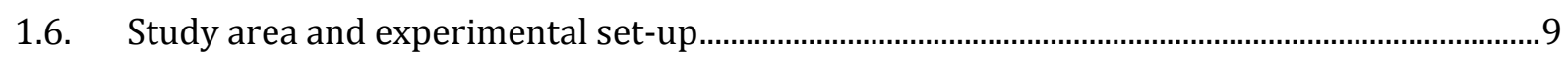

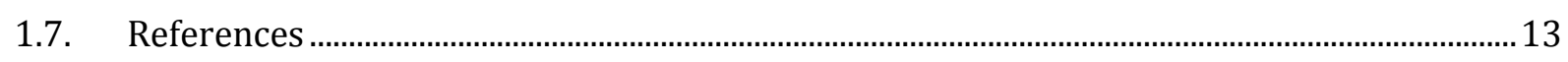

Chapter 2: Stem and soil nitrous oxide fluxes from rainforest and cacao agroforest on highly weathered soils in the Congo Basin ................................................................................ 20

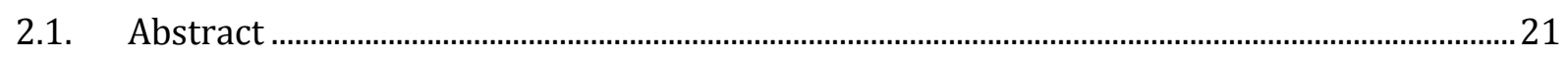

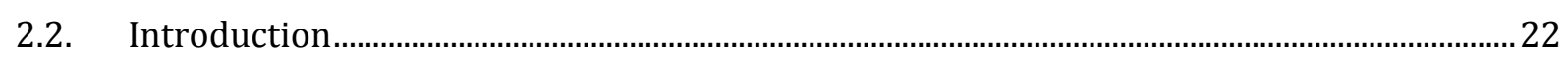

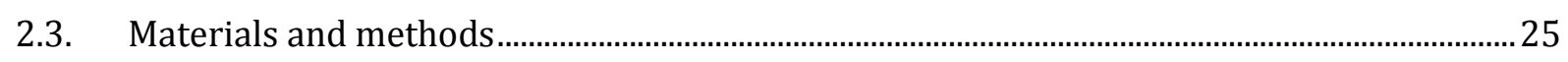

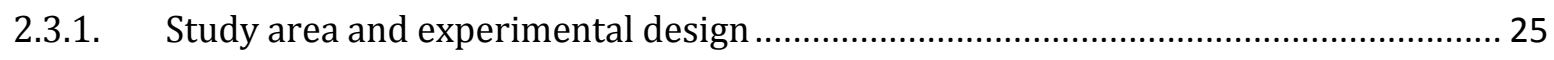

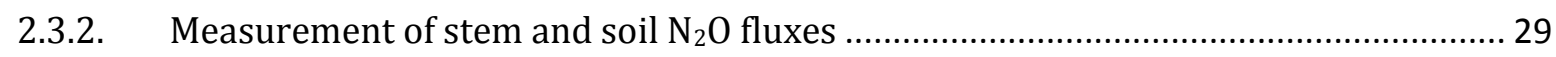

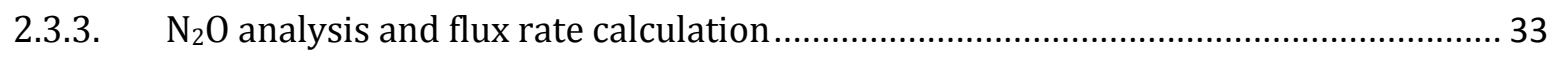

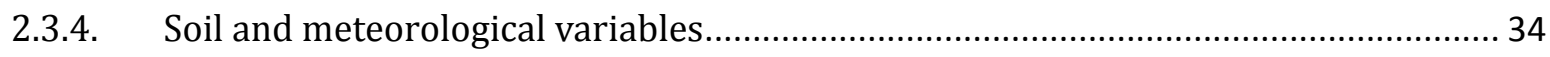

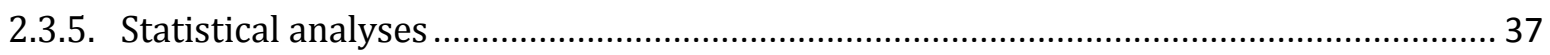

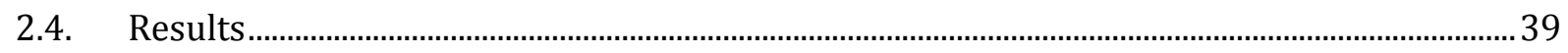

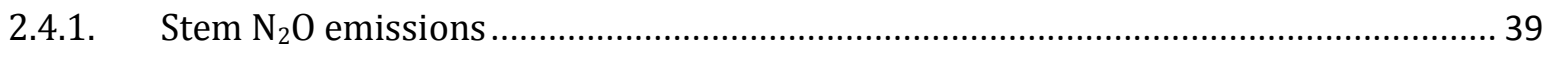

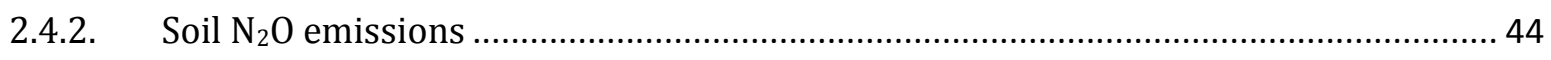

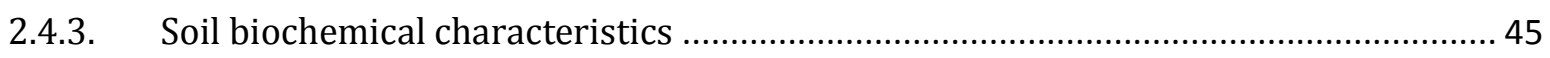

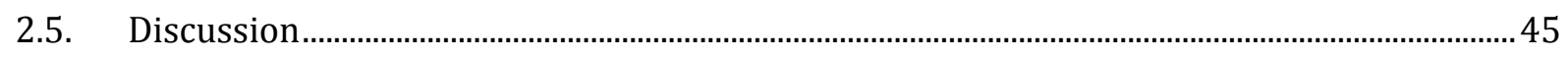

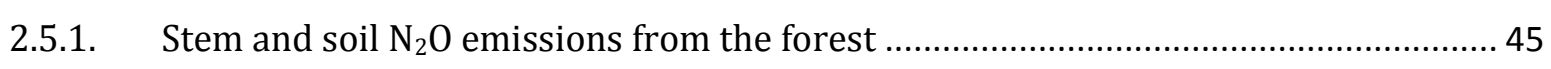

2.5.2. Source of tree-stem $\mathrm{N}_{2} \mathrm{O}$ emissions and their contribution to total (soil + stem) $\mathrm{N}_{2} \mathrm{O}$

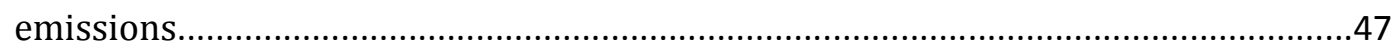

2.5.3. Factors controlling temporal variability of stem and soil $\mathrm{N}_{2} \mathrm{O}$ fluxes........................ 48

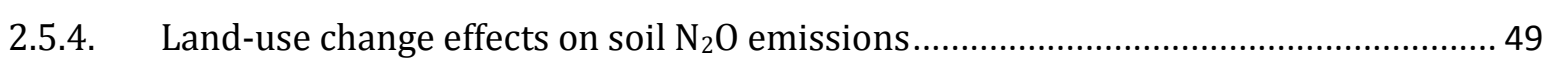

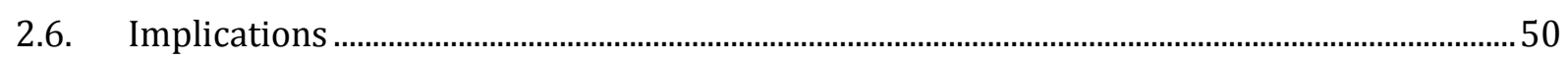

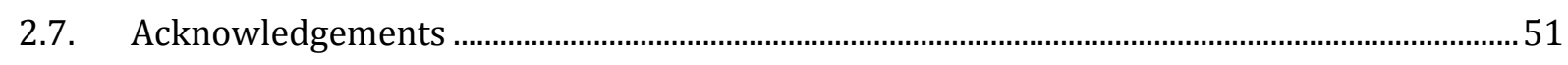

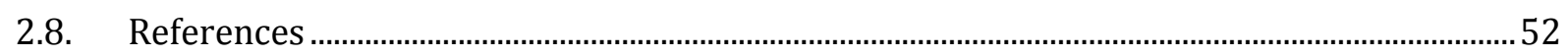

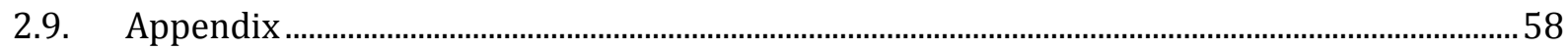


Chapter 3: Tree stem and soil methane and carbon dioxide fluxes from rainforest and cacao agroforest on highly weathered soils in the Congo Basin ...................................................60

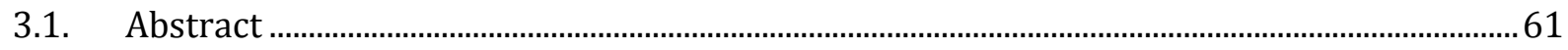

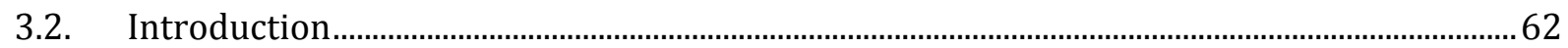

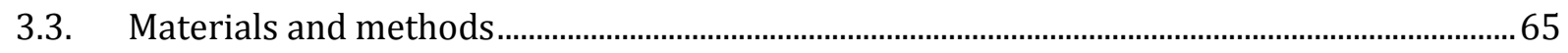

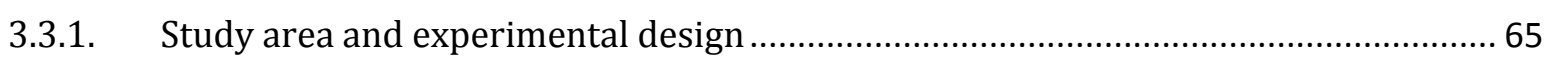

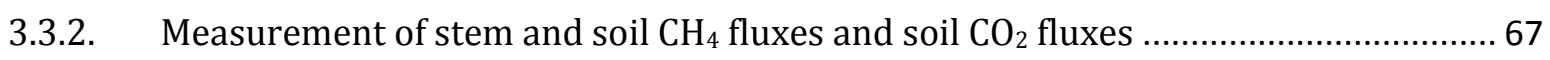

3.3.3. Trace greenhouse gas analysis and flux rate calculation............................................ 69

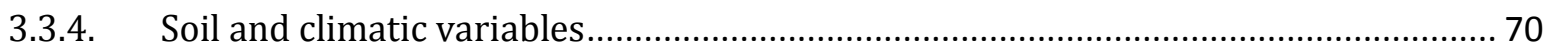

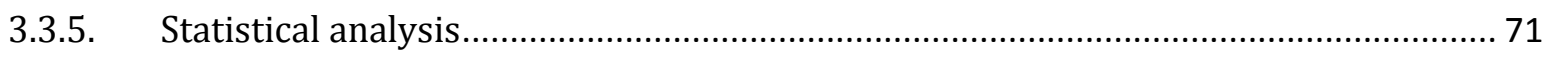

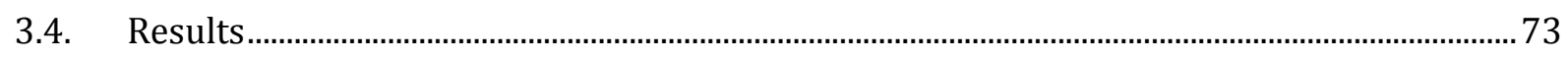

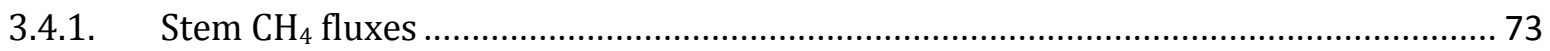

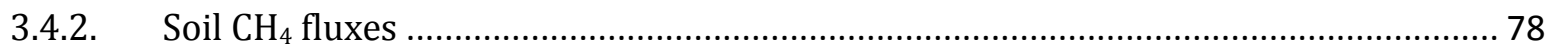

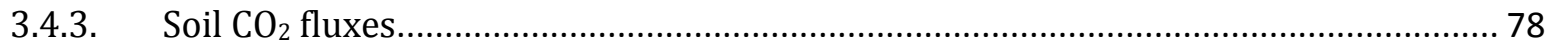

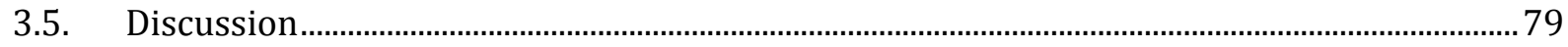

3.5.1. Stem $\mathrm{CH}_{4}$ emissions and their contribution to total (soil + stem) $\mathrm{CH}_{4}$ emissions ...... 79

3.5.2. Factors controlling temporal and spatial variability of soil fluxes ............................. 83

3.5.3. Effects of land-use change on soil $\mathrm{CO}_{2}$ and $\mathrm{CH}_{4}$ fluxes ........................................... 85

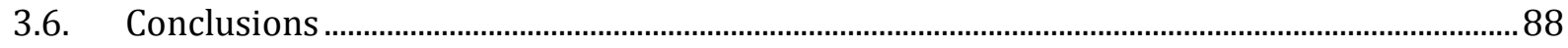

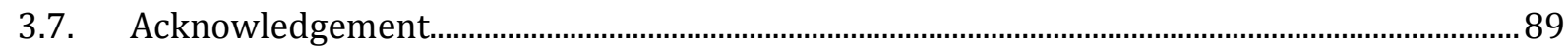

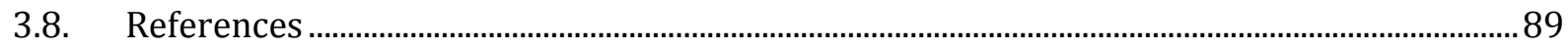

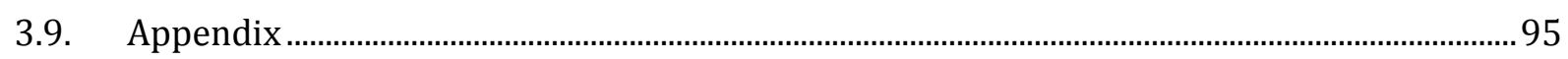

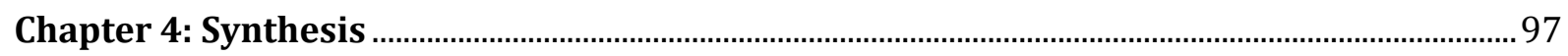

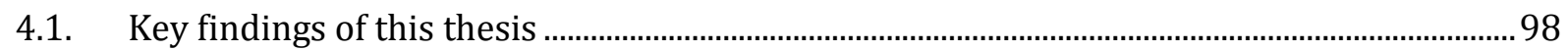

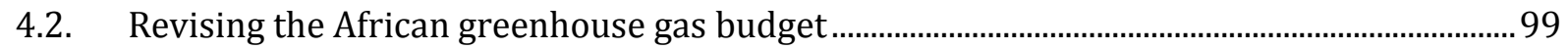

4.3. Tree stem emissions and implications for global greenhouse gas budgets .......................... 103

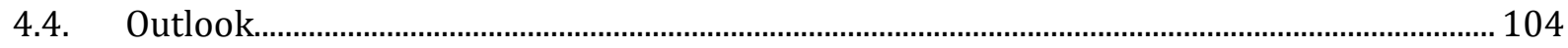

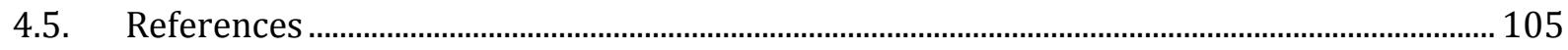

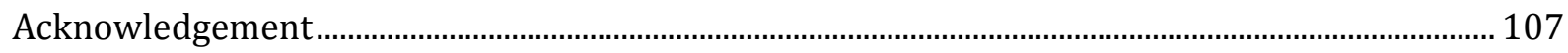

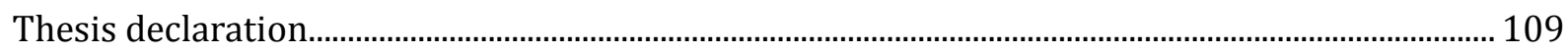

Curriculum vitae......................................................................................... Error! Bookmark not defined. 


\section{SUMMARY}

Tropical rainforests play a crucial role in biogeochemical cycles and global climate dynamics. Yet, research efforts to quantify the main sources and sinks of trace greenhouse gases lags behind that of other biomes. The African continent is among the least researched regions worldwide, and the effects of land-use change on trace greenhouse gases are identified as an important research gap in the greenhouse gas budget of Africa. Recent studies in wetland and temperate forests have provided evidence for tree stem nitrous oxide $\left(\mathrm{N}_{2} \mathrm{O}\right)$ and methane $\left(\mathrm{CH}_{4}\right)$ emissions, but the magnitudes of tree contributions to total (soil + stem) $\mathrm{N}_{2} \mathrm{O}$ and $\mathrm{CH}_{4}$ emissions from tropical rainforests on heavily weathered soils remain unknown. Given these knowledge gaps, this thesis consists of two studies aimed at quantifying the changes in stem and soil $\mathrm{N}_{2} \mathrm{O}$ and $\mathrm{CH}_{4}$ fluxes, and soil carbon dioxide $\left(\mathrm{CO}_{2}\right)$ fluxes with forest conversion to cacao agroforestry. The study was conducted at three sites (villages) in central and southern Cameroon, all located on heavily weathered soils. To assess the impact of land-use change on stem and soil greenhouse gas fluxes, we studied two land-use systems at each site: the reference forest and the converted cacao agroforestry system. At each site, we selected four replicate plots $\left(2500 \mathrm{~m}^{2}\right.$ each) for each land use. Soil and stem greenhouse gas fluxes were measured monthly using vented static chambers ( 4 chambers per plot) and stem chambers (6 trees per plot), respectively, from April 2017 to April 2018. On each measurement period, we also measured known soil and climatic controlling factors.

The aim of the first study was to quantify the changes in stem and soil $\mathrm{N}_{2} \mathrm{O}$ fluxes with forest conversion to cacao agroforestry. Additionally, we conducted a ${ }^{15} \mathrm{~N}$ tracing experiment at one of the sites as a follow-on study to elucidate the source of stem $\mathrm{N}_{2} \mathrm{O}$ emissions. Our findings revealed that trees on well-drained, heavily weathered soils served as an important $\mathrm{N}_{2} \mathrm{O}$ emission pathway, with the potential to overlook up to $38 \%$ of fluxes in the forests, and 
up to $15 \%$ of fluxes in cacao agroforests, if tree stems are not considered in the ecosystem $\mathrm{N}_{2} \mathrm{O}$ budget. ${ }^{15} \mathrm{~N}$-isotope tracing from soil mineral $\mathrm{N}$ to stem-emitted ${ }^{15} \mathrm{~N}_{2} \mathrm{O}$ suggest that emitted $\mathrm{N}_{2} \mathrm{O}$ from stems originated predominantly from $\mathrm{N}_{2} \mathrm{O}$ produced in the soil. Additionally, forest conversion to cacao agroforestry systems had no effect on stem and soil $\mathrm{N}_{2} \mathrm{O}$ emissions, because of similarities in soil moisture and soil texture, absence of fertilizer application, and comparable presence of leguminous trees in both land uses, which can compensate for $\mathrm{N}$ export from harvest or other losses.

For our second study, we investigated the changes in stem and soil $\mathrm{CH}_{4}$ fluxes and soil $\mathrm{CO}_{2}$ fluxes with forest conversion to cacao agroforestry. Conversion of forest to cacao agroforestry had no effect on stem and soil $\mathrm{CH}_{4}$ and $\mathrm{CO}_{2}$ fluxes. The lack of differences may be due to the comparable soil texture and soil moisture content between the two land uses, which influences gas diffusivity into and out of the soil. All the studied trees emitted measurable $\mathrm{CH}_{4}$ at some point during the study period. In both land uses, tree stems were net sources of $\mathrm{CH}_{4}$, while the soils were net $\mathrm{CH}_{4}$ sinks. Our upscaling suggests that tree stem emissions offset $3-18 \%$ of the annual soil $\mathrm{CH}_{4}$ sink in both land uses.

This study provides the first year-round and spatially replicated quantifications of stem and soil trace gas fluxes for the Congo Basin, with key implications for improved estimates of trace gas budgets for Africa. Our results show for the first time that, $\mathrm{N}_{2} \mathrm{O}$ and $\mathrm{CH}_{4}$ emissions from tree stems on well-drained soils are apparently widespread and detectable in many tropical trees in Africa. As discussed in the synthesis chapter, even low stem trace gas emissions at the ecosystem level can upscale to significant fluxes globally. These findings emphasize the need for additional studies on tree stem fluxes in order to constrain their magnitudes and mechanisms, and to refine global greenhouse gas budgets. 


\section{ZUSAMMENFASSUNG}

Tropische Regenwälder spielen eine entscheidende Rolle in biogeochemischen Kreisläufen und der globalen Klimadynamik. Dennoch bleiben die Forschungsbemühungen zur Quantifizierung der Hauptquellen und -senken von Treibhausgasen hinter denen anderer Biome zurück. Der afrikanische Kontinent gehört zu den am wenigsten erforschten Regionen weltweit, und die Auswirkungen von Landnutzungsänderungen auf Treibhausgase stellen eine wichtige Forschungslücke im Treibhausgasbudget Afrikas dar. Jüngste Studien in Feuchtgebieten und gemäßigten Wäldern haben Nachweise für die Distickstoffmonoxid- $\left(\mathrm{N}_{2} \mathrm{O}\right)$ und Methan- $\left(\mathrm{CH}_{4}\right)$ Emissionen von Baumstämmen geliefert, aber die Größenordnung der Beiträge der Bäume zu den gesamten (Boden + Stamm) $\mathrm{N}_{2} \mathrm{O}$ - und $\mathrm{CH}_{4}$-Emissionen aus tropischen Regenwäldern auf stark verwitterten Böden bleibt unbekannt. Angesichts dieser Wissenslücken besteht diese Arbeit aus zwei Studien, die darauf abzielen, Veränderungen der $\mathrm{N}_{2} \mathrm{O}$ - und $\mathrm{CH}_{4}$-Flüsse in Stamm und Boden, sowie die Kohlenstoffdioxid $\left(\mathrm{CO}_{2}\right)$-Flüsse im Boden bei der Umwandlung von Wald in Kakao-Agroforstwirtschaft zu quantifizieren. Die Studie wurde an drei Standorten (Dörfern) in Zentral- und Südkamerun durchgeführt, die alle auf stark verwitterten Böden liegen. Um die Auswirkungen von Landnutzungsänderungen auf die Treibhausgasflüsse von Stamm und Boden zu bewerten, untersuchten wir an jedem Standort zwei Landnutzungssysteme: den Referenzwald und das umgestellte Kakao-Agroforstsystem. An jedem Standort wählten wir für jede Landnutzung vier Wiederholungsflächen (je $2500 \mathrm{~m}^{2}$ ) aus. Die Boden- und Stamm-Treibhausgasflüsse wurden von April 2017 bis April 2018 monatlich mit belüfteten statischen Hauben (4 Hauben pro Fläche) bzw. Stamm-Hauben (6 Bäume pro Fläche) gemessen. In jeder Messperiode wurden auch bekannte boden- und klimaregulierende Faktoren gemessen. 
Das Ziel der ersten Studie war es, die Veränderungen der $\mathrm{N}_{2} \mathrm{O}$-Flüsse in Stamm und Boden bei der Umwandlung von Wald in Kakao-Agroforstwirtschaft zu quantifizieren. Zusätzlich führten wir als Folgestudie ein ${ }^{15} \mathrm{~N}$-Rückverfolgungsexperiment an einem der Standorte durch, um die Quelle der Stamm- $\mathrm{N}_{2} \mathrm{O}$-Emissionen ausfindig zu machen. Unsere Ergebnisse zeigten, dass Bäume auf gut entwässerten, stark verwitterten Böden als wichtiger $\mathrm{N}_{2} \mathrm{O}$-Emissionspfad dienten, mit dem Potenzial, bis zu 38\% der Flüsse in den Wäldern und bis zu 15\% der Flüsse in den Kakao-Agroforstwäldern zu übersehen, wenn die Baumstämme nicht im $\mathrm{N}_{2} \mathrm{O}$-Budget des Ökosystems berücksichtigt werden. Die Rückverfolgung des ${ }^{15} \mathrm{~N}$-Isotops vom mineralischen Bodenstickstoff auf das von den Stämmen emittierte ${ }^{15} \mathrm{~N}_{2} \mathrm{O}$ lässt vermuten, dass das von den Stämmen emittierte $\mathrm{N}_{2} \mathrm{O}$ überwiegend aus dem im Boden produzierten $\mathrm{N}_{2} \mathrm{O}$ stammt. Darüber hinaus hatte die Umstellung der Wälder auf Kakao-Agroforstwirtschaft keine Auswirkungen auf die $\mathrm{N}_{2} \mathrm{O}$-Emissionen von Stämmen und Böden aufgrund von Ähnlichkeiten in der Bodenfeuchte und Bodenbeschaffenheit, Abwesenheit von Düngemittel und vergleichbarer Präsenz von leguminosen Baumarten in beiden Landnutzungssystemen, was den Stickstoff- Export aus Ernte oder anderen Verlusten ausgleichen kann.

Für unsere zweite Studie untersuchten wir Veränderungen der $\mathrm{CH}_{4}$-Flüsse in Stamm und Boden sowie die $\mathrm{CO}_{2}$-Flüsse im Boden bei der Umwandlung von Wald in KakaoAgroforstwirtschaft. Die Umwandlung von Wald in Kakao-Agroforstwirtschaft hatte keine Auswirkungen auf die $\mathrm{CH}_{4}$ - und $\mathrm{CO}_{2}$-Flüsse von Stamm und Boden. Die Abwesenheit von Unterschieden könnte auf die vergleichbare Bodentextur und Bodenfeuchtigkeit zwischen beiden Landnutzungen zurückzuführen sein, welche das Diffusionsvermögen von Gasen in den Boden hinein und aus dem Boden heraus beeinflussen. Alle untersuchten Bäume emittierten irgendwann während der Untersuchungsperiode messbares $\mathrm{CH}_{4}$. In beiden Landnutzungen waren die Baumstämme Nettoquellen von $\mathrm{CH}_{4}$, während die Böden Netto- $\mathrm{CH}_{4}$-Senken waren. 
Unsere Hochskalierung deutet darauf hin, dass die Baumstammemissionen 3 bis $18 \%$ der jährlichen $\mathrm{CH}_{4}$-Senkung des Bodens in beiden Landnutzungen ausgleichen.

Diese Studie liefert die ersten ganzjährigen und räumlich replizierten Quantifizierungen der Stamm- und Boden-Spurengasflüsse für das Kongobecken, mit entscheidenden Auswirkungen auf verbesserte Schätzungen der Spurengasbudgets für Afrika. Unsere Ergebnisse zeigen zum ersten Mal, dass $\mathrm{N}_{2} \mathrm{O}$ - und $\mathrm{CH}_{4}$-Emissionen von Baumstämmen auf gut entwässerten Böden offenbar weit verbreitet und bei vielen tropischen Bäumen in Afrika nachweisbar sind. Wie im Synthesekapitel erörtert, können selbst geringe Spurengasemissionen von Baumstämmen auf Ökosystemebene zu signifikanten Strömen weltweit führen. Diese Ergebnisse unterstreichen die Notwendigkeit zusätzlicher Studien über die Baumstamm-Flüsse, um ihre Größenordnung und Mechanismen $\mathrm{zu}$ begrenzen und die globalen Treibhausgasbudgets weiter zu verfeinern. 


\section{ChAPTER 1}

GENERAL INTRODUCTION 


\subsection{The role of the tropics in the global trace greenhouse gas budgets}

Carbon dioxide $\left(\mathrm{CO}_{2}\right)$, nitrous oxide $\left(\mathrm{N}_{2} \mathrm{O}\right)$ and methane $\left(\mathrm{CH}_{4}\right)$ constitute the most important long-lived greenhouse gases (GHG) in the atmosphere. $\mathrm{CO}_{2}$ has a longer atmospheric lifetime (5-200 years) than both $\mathrm{N}_{2} \mathrm{O}$ (114 years) and $\mathrm{CH}_{4}$ (12 years) (Forster et al., 2007), and the absolute quantity of emitted $\mathrm{CO}_{2}$ exceeds that of $\mathrm{N}_{2} \mathrm{O}$ and $\mathrm{CH}_{4}$ by several orders of magnitude (Oertel et al., 2016). However, $\mathrm{N}_{2} \mathrm{O}$ and $\mathrm{CH}_{4}$ causes 263 and 32 times more radiative forcing, respectively, than $\mathrm{CO}_{2}$ by mass over a century (Neubauer \& Megonigal, 2015), making these gases equally relevant to climate studies. Despite the high vulnerability of biogeochemical cycles in tropical ecosystems to climatic changes, trace gas budgets remain poorly constrained for these important ecosystems.

Tropical soils are one of the largest natural source of $\mathrm{CO}_{2}$, contributing $c a .58 \mathrm{Pg} \mathrm{C} \mathrm{yr}^{-1}$ to the estimated global soil respiration of about $91 \mathrm{Pg} \mathrm{C} \mathrm{yr}^{-1}$ (Hashimoto et al., 2015), although previous estimates suggest lower global $\mathrm{CO}_{2}$ effluxes of between 68 and $78 \mathrm{Pg} \mathrm{C} \mathrm{yr}^{-1}$ (Raich \& Potter, 1995; Raich \& Schlesinger, 1998; Hashimoto, 2012). This efflux of respiratory carbon from the soil to the atmosphere largely offsets global atmospheric $\mathrm{CO}_{2}$ uptake by terrestrial plants (Beer et al., 2010; Richardson et al., 2019). Net soil $\mathrm{CO}_{2}$ flux is largely a product of heterotrophic (soil microbial respiration) and autotrophic (root respiration) respiration processes (Luo \& Zhou, 2006). The proximal controlling factors of soil $\mathrm{CO}_{2}$ efflux are soil temperature and moisture, but are also influenced by spatial differences in soil texture, substrate availability and vegetation type (Raich \& Schlesinger, 1998; Luo \& Zhou, 2006).

Soil processes are considered to be the most important natural source of global $\mathrm{N}_{2} \mathrm{O}$, with fluxes from natural and agricultural soils accounting for $56-70 \%$ of global $\mathrm{N}_{2} \mathrm{O}$ emissions (Syakila \& Kroeze, 2011). Using ground-based, bottom-up approaches, recent estimates of $\mathrm{N}_{2} \mathrm{O}$ emissions from tropical rainforest soils come up with lower values of $1.1 \mathrm{Tg} \mathrm{N}_{2} \mathrm{O}-\mathrm{N} \mathrm{yr}{ }^{-1}$ 
(Stehfest \& Bouwman, 2006) and $1.3 \mathrm{Tg} \mathrm{N}_{2} \mathrm{O}-\mathrm{N} \mathrm{yr}{ }^{-1}$ (Werner et al., 2007) than earlier best estimates of 2.3 Tg N2O-N yr${ }^{-1}$ (Bouwman et al., 1995) and $3.5 \mathrm{Tg} \mathrm{N}_{2} \mathrm{O}-\mathrm{N} \mathrm{yr}^{-1}$ (Breuer et al., 2000). Although a wealth of microbial metabolic pathways and abiotic processes can produce $\mathrm{N}_{2} \mathrm{O}$ in the soil, the contrasting microbial processes of nitrification and denitrification forms the most dominant processes of soil $\mathrm{N}_{2} \mathrm{O}$ production, contributing $c a$. $70 \%$ of global $\mathrm{N}_{2} \mathrm{O}$ emissions (Syakila \& Kroeze, 2011). The activities of these nitrifying/denitrifying bacterial communities are affected by proximal environmental factors such as nitrogen $(\mathrm{N})$ availability, soil moisture, soil temperature and soil pH (Davidson et al., 2000a; Kesik et al., 2006; Butterbach-Bahl et al., 2013).

Tropical forest soils also constitute one of the largest biogenic sink of atmospheric $\mathrm{CH}_{4}$ (Dutaur \& Verchot, 2007). $\mathrm{CH}_{4}$ flux at the soil-atmosphere interface is a net result of the simultaneous activities of methanogens $\left(\mathrm{CH}_{4}\right.$ producers under anaerobic conditions) and methanotrophs $\left(\mathrm{CH}_{4}\right.$ consumers under aerobic conditions). For well-drained soils, $\mathrm{CH}_{4}$ oxidation by methanotrophic bacteria exceeds $\mathrm{CH}_{4}$ production, resulting in a net uptake of 20 to $45 \mathrm{Tg} \mathrm{CH}_{4}-\mathrm{C} \mathrm{yr}^{-1}$ at the global scale (Dutaur \& Verchot, 2007; Kirschke et al., 2013; Schlesinger \& Bernhardt, 2013). Soil $\mathrm{CH}_{4}$ fluxes are largely controlled by soil moisture, which influences gas diffusivity into and out of the soil (Verchot et al., 2000; Veldkamp et al., 2013; Matson et al., 2017), and soil $\mathrm{N}$ availability, through its influence on the activities of methanotrophs (Bodelier \& Laanbroek, 2004).

Tropical ecosystems continue to play an important role in biogeochemical cycles and global climate, yet, research efforts to quantify the main sources and sinks of trace GHG lags behind that of other biomes, with the African continent among the most under researched region worldwide (Kim et al., 2016b). Presently, trace gas budgets from the African continent are poorly constrained due to the lack of data on biogenic fluxes of trace GHG (Bombelli et al., 
2009; Ciais et al., 2011; Valentini et al., 2014). Africa may be a small carbon sink (-0.04 Pg C $\mathrm{yr}^{-1}$; Fisher et al., 2013), nevertheless, the emissions of $\mathrm{N}_{2} \mathrm{O}$ and $\mathrm{CH}_{4}$ may turn the continent into a net source of GHG (Valentini et al., 2014). Paradoxically, for several decades now, plant productivity and biomass in African tropical forests have reportedly increased due to increasing atmospheric $\mathrm{CO}_{2}$ concentrations, resulting in net carbon gains (Cao et al., 2001; Lewis et al., 2009; Ciais et al., 2011). However, recent findings suggest a potential slowdown in the carbon sink strength of African tropical forests during the last decade (Hubau et al., 2020), due to increasing tree mortality and reduced tree growth, as a result of heat stress and extreme drought events, among other limiting factors (Allen et al., 2010; Hubau et al., 2020). Hubau et al. (2020) went on to predict that the carbon sink strength of African tropical forests might decline by $14 \%$ by the year 2039. Conversely, the prediction by Hubau et al. (2020) is in stark contrast to model projections of continuous high carbon uptake by Africa tropical forests up to the year 2100 (Huntingford et al., 2013). Such inconsistencies underline the need to pursue field research efforts aimed at improving trace gas budget estimations for the African continent. In the recent study on a greenhouse gas budget for Africa, one of the key uncertainties mentioned was: "Non$\mathrm{CO}_{2}$ greenhouse gas emissions are poorly studied across the various African ecosystems (...) The lack of such information hinders the understanding of the African methane budget (...) and insight on the natural sources of nitrous oxide" (Valentini et al., 2014, pg. 400).

\subsection{Trees as conduits of $\mathrm{N}_{2} \mathrm{O}$ and $\mathrm{CH}_{4}$ fluxes}

For some decades, plants have been shown to contribute to GHG emissions by acting as conduits for trace gases, facilitating the transport between the soil, where gases are produced or consumed by microbial activity, and the atmosphere. Here, trace GHG emissions may originate from root uptake of dissolved gases produced in the soil, and then conveyed to the atmosphere via aerenchyma tissue (Cicerone \& Shetter, 1981; Butterbach-Bahl et al., 1997) or transpiration 
stream (Chang et al., 1998). Earlier studies investigating the role of plants as conduits for soilproduced trace gases focused on herbaceous species, where the contribution of plant-mediated trace gas emissions were reported to make up to $90 \%$ of the total (plant + soil) emission (Singh \& Singh, 1995; Butterbach-Bahl et al., 1997; Yu et al., 1997; Chen et al., 2002).

Trace gas emissions from trunks of woody trees were initially suggested by Schütz et al. (1991), but actual data on $\mathrm{CH}_{4}$ and $\mathrm{N}_{2} \mathrm{O}$ emissions from trees were first reported for seedlings of black alder (Alnus glutinosa), a tree species that typically grows in European wetlands (Rusch \& Rennenberg, 1998). Later studies also reported mangrove trees and tropical swamp trees to emit trace gases (Gauci et al., 2010; Pangala et al., 2013; Terazawa et al., 2015). These trees, which are adapted to wetlands, have aerenchyma tissue which facilitates egress of soilproduced $\mathrm{CH}_{4}$ via gas transport through the tree, and exchange with the atmosphere appears to happen predominantly through lenticels in stems (Buchel \& Grosse, 1990). The described stem emission pathway has mostly been demonstrated in the field for $\mathrm{CH}_{4}$ (Pangala et al., 2014; Terazawa et al., 2015). Also, $\mathrm{N}_{2} \mathrm{O}$ can be transported through the aerenchyma system; however, preferential transport mechanism appears to be through dissolution in xylem sap flow and exchange with the atmosphere through stomata or the stem surface (Machacova et al., 2013; Wen et al., 2017). Accordingly, $\mathrm{N}_{2} \mathrm{O}$ emissions have also been observed in seedlings from trees that have no aerenchyma, like Fagus sylvatica (Machacova et al., 2013).

Tree-stem trace gas fluxes have been found to be largely controlled by tree physiology and traits of wood anatomy. For example, it has been shown in tropical peatlands that small trees and trees with a low wood specific density are correlated with high $\mathrm{CH}_{4}$ emissions (Pangala et al., 2013). The density of stem lenticels also correlated positively with stem $\mathrm{CH}_{4}$ emissions (Pangala et al., 2014), while stem $\mathrm{N}_{2} \mathrm{O}$ and $\mathrm{CH}_{4}$ emissions varied significantly among species in both upland (Pitz \& Megonigal, 2017; Wen et al., 2017; Welch et al., 2019) and 
wetland forests (Pangala et al., 2015; Pitz et al., 2018). Additionally, soil moisture content, temperature, and soil trace gas concentrations have all been found to correlate with stem emissions and thus may control them (Machacova et al., 2013; Pangala et al., 2015; Wen et al., 2017).

Until now, it is unknown whether trees on heavily weathered soils in lowland tropical forests, such as in our study sites, contribute to $\mathrm{N}_{2} \mathrm{O}$ and $\mathrm{CH}_{4}$ emissions. However, some factors suggest that emissions through stems are possible: high $\mathrm{N}_{2} \mathrm{O}$ concentrations in the soil are common in lowland tropical forest soils especially during the wet season when values as high as 4 to $8 \mathrm{ppm} \mathrm{N}_{2} \mathrm{O}$ (compared to atmospheric concentration of $0.32 \mathrm{ppm} \mathrm{N}_{2} \mathrm{O}$ ) have been measured (i.e. Brazil: Perez et al., 2000). Additionally, Welch et al. (2019) measured high treestem $\mathrm{N}_{2} \mathrm{O}$ and $\mathrm{CH}_{4}$ emissions in humid tropical forests in Panama. Over a short measurement campaign ( 2 weeks), annual tree-stem emissions were found to contribute up to $18 \%$ to total forest emissions (Machacova et al., 2016). In another study, the inclusion of tree-stem fluxes from floodplain trees in bottom-up $\mathrm{CH}_{4}$ inventories closed the Amazon $\mathrm{CH}_{4}$ budget (Pangala et al., 2017). Despite the evidence for tree stem emissions, estimations of global trace gas budgets generally assumes soils to be the only active surfaces emitting trace gases, thereby excluding the contributions of trees (Syakila \& Kroeze, 2011; Hashimoto et al., 2015; Saunois et al., 2016). It is possible that tree stem emissions may be the "missing" emission pathways needed to explain the mismatches in trace gas estimates between ground-based, bottom-up models and top-down modelling and atmospheric inversion methods (Werner et al., 2007; Thompson et al., 2014; Saunois et al., 2016). Given the extensive coverage of well-drained tropical forests relative to tropical wetlands, it is imperative that tree stem emissions in tropical upland forests are measured over sufficient spatial and temporal variability in order to provide insights on stem flux magnitudes and underlying mechanisms, and their role in global trace gas budgets. 


\subsection{Effects of land-use change on trace gas fluxes}

Although the number of studies on trace gas fluxes from tropical land uses is still limited, it has become clear that forest conversion and agricultural intensification contribute to the increasing trace gas emissions from soils (Veldkamp \& Keller, 1997). The current pattern of deforestation in Africa is similar to the rest of the tropics, with an estimated 3.4 million ha of forest converted to agricultural lands yearly in Africa (Kim et al., 2016b). Consequently, a study on the GHG budget of Africa reported land-use change to be the dominant source of trace gas emissions in Africa, resulting in an estimated emission of $0.32 \pm 0.05 \mathrm{Pg} \mathrm{C} \mathrm{yr}^{-1}$ (Valentini et al., 2014). This estimated budget was found to be even higher than emissions from fossil fuels, which is unique for the African continent.

Tropical forest conversion to other land uses affects trace gas fluxes due to changes in physicochemical properties of soil (Veldkamp et al., 2008; Hassler et al., 2015, 2017). For example, changes in soil $\mathrm{CO}_{2}$ fluxes following forest conversion have been related to changes in root mass (Bae et al., 2013), litter input and soil organic carbon stocks (Hassler et al., 2015). Land use associated changes in soil $\mathrm{N}_{2} \mathrm{O}$ fluxes are predominantly controlled by changes in soil $\mathrm{N}$ availability and soil water content (Davidson et al., 2000a), whereas changes in soil $\mathrm{CH}_{4}$ fluxes have been linked to differences in gas diffusivity due to soil compaction (Corre et al., 2006; Veldkamp et al., 2008). How land use affect non- $\mathrm{CO}_{2}$ greenhouse gas fluxes was identified as a research gap in the recent greenhouse gas budget for Africa (Valentini et al., 2014).

\subsection{The Congo Basin, Cameroon}

The Congo Basin forest is the second largest intact tropical rainforest in the world after the Amazon, making it an important repository of biodiversity and other ecosystem services. It is home to about 20,000 plant species of which 8,000 are endemic (Billand, 2012). The Congo 
Basin is estimated to store $c a .57$ billion $\mathrm{t}$, representing $21 \%$ of the total $\mathrm{C}$ stored in tropical forests globally (FAO, 2011). It is also important to global precipitation patterns, as it has the highest amount of rainfall during the transition seasons (Washington et al., 2013). These signify the Basin's significance to terrestrial carbon cycling and global climate. While Africa has been underrepresented in trace gas flux research, studies from the Congo Basin are almost absent, possibly due to chronic political instability and limited logistical support (Verbeeck et al., 2011).

Cameroon, which shares the Congo Basin, is the second highest deforested country behind the Democratic Republic of Congo (Dkamela, 2010). Forest clearing for small-scale agriculture has been found to be the dominant cause of deforestation in the region, accounting for more than $90 \%$ of forest cover loss (Tyukavina et al., 2018). Most of the cleared forest areas are used to establish cacao agroforests, especially in densely populated areas such as central and south Cameroon. And like many other African countries where cacao agroforests dominate agricultural production, the conversion of forest for the establishment of cacao farms have mostly being unselective. Nevertheless, most of these small-scale cacao farms, presently estimated to be $c a .400,000$ hectares, are hand planted under the shade of forests' remnant trees with no fertilizer inputs (Kotto et al., 2002; Saj et al., 2013), making these cacao agroforests one of the most sustainable land-use systems in Central and West Africa forest zones.

\subsection{Aims and hypotheses}

Despite disparity of estimates for African trace gas budget between bottom-up and top-down approaches, no study has concurrently quantified soil and stem trace gas emissions from Africa. The research presented in this thesis aimed to provide a systematic comparison between a reference land use and a converted system for quantifying land-use change effects on stem and soil trace gas fluxes, which are virtually lacking for the Congo Basin, and thus an important 
contribution in the improvement of greenhouse gas budget of Africa. This study therefore provides the first year-round, multiple site quantifications for forests and cacao agroforestry systems in the Congo Basin, including 23 tree species that have not been measured before.

This thesis consists of two studies carried out at three sites across central and southern Cameroon. The aims of the first study were to quantify the changes in stem and soil $\mathrm{N}_{2} \mathrm{O}$ fluxes with forest conversion to cacao agroforestry, and to determine the temporal and spatial controls of stem and soil $\mathrm{N}_{2} \mathrm{O}$ fluxes. In this study, we hypothesized that: (i) stem and soil $\mathrm{N}_{2} \mathrm{O}$ fluxes from these extensively managed CAF systems will be comparable to the natural forests, and (ii) the seasonal pattern of stem emissions will parallel that of soil $\mathrm{N}_{2} \mathrm{O}$ emissions and both will have similar soil and climatic controlling factors.

In the second study, we quantified changes in stem and soil $\mathrm{CH}_{4}$ and soil $\mathrm{CO}_{2}$ fluxes with forest conversion to $\mathrm{CAF}$, and determined the temporal and spatial controls of stem and soil $\mathrm{CH}_{4}$ and $\mathrm{CO}_{2}$ fluxes. The following hypotheses were tested: (i) stem and soil $\mathrm{CH}_{4}$ fluxes from these extensively managed CAF systems will be comparable to the natural forests, (ii) trees from tropical forests and cacao agroforestry emit $\mathrm{CH}_{4}$ from stems, and (iii) stem emissions will offset a considerable fraction of the net $\mathrm{CH}_{4}$ consumption by soils.

\subsection{Study area and experimental set-up}

Our research was conducted at three sites located in southern and central regions of Cameroon, where natural forest conversion into cacao agroforestry systems is common. Sites in the southern region were located around the villages of Aloum and Biba Yezoum, and the third site was located around the village of Tomba. To investigate the effects of land-use change on trace gas fluxes, we examined two land-use systems at each site: the reference forest and the converted cacao agroforestry system, each represented by four replicate plots (Fig. 1.1). In total, 
we measured stem and soil trace gas fluxes in 24 plots ( 3 sites $\times 2$ land uses $\times 4$ replicate plots) all located on relatively flat topography. All sites were located on heavily weathered soils which are classified as Ferralsols (IUSS Working Group WRB, 2015).

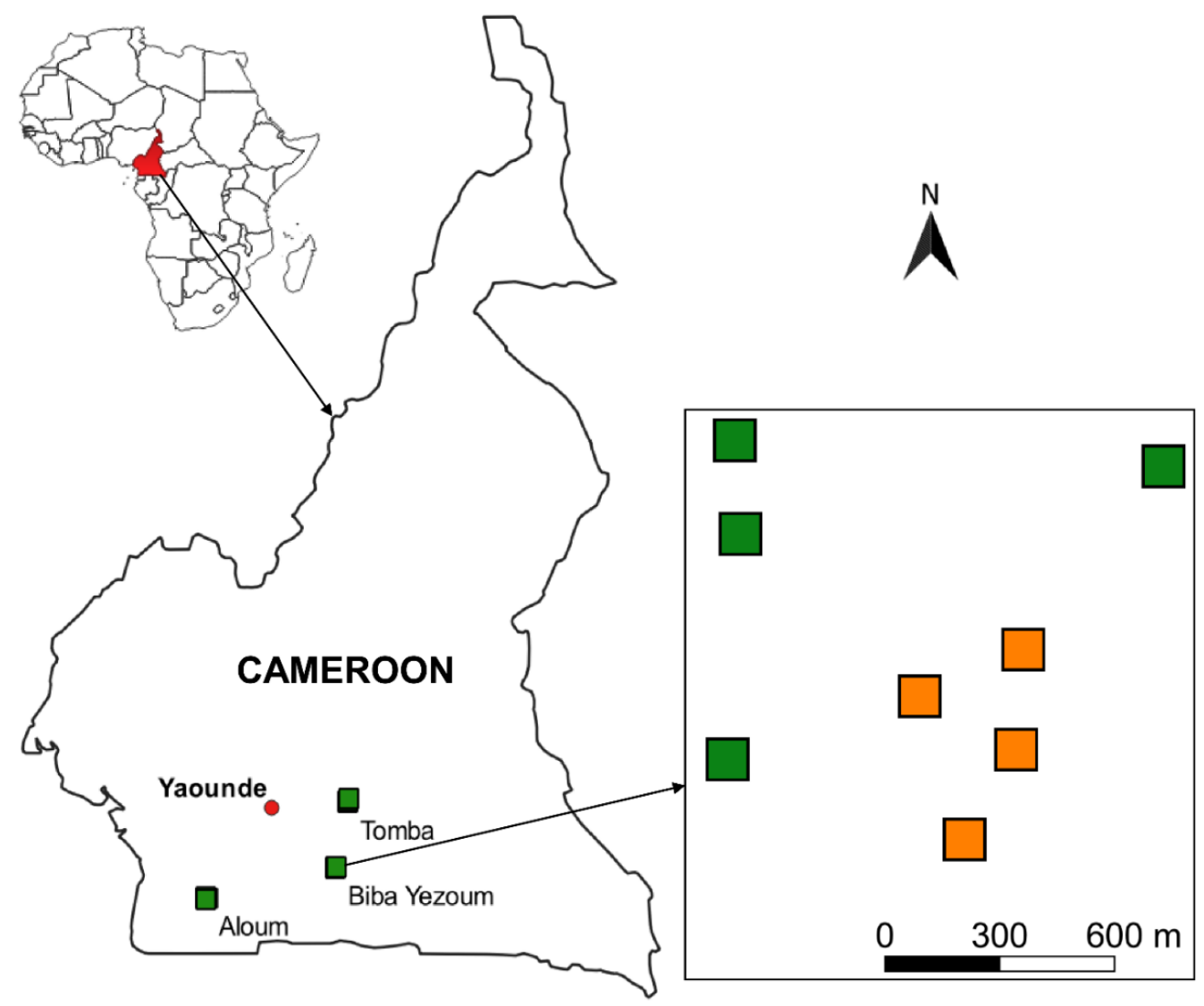

Figure 1. 1. Location of the study sites in Cameroon, showing the four replicate plots per land use (green for forests and orange for cacao agroforestry) at one site.

All the study sites are characterised by significant rainfall in most months of the year, spanning an annual precipitation from $1576 \mathrm{~mm} \mathrm{yr}^{-1}$ in the centre to $2064 \mathrm{~mm} \mathrm{yr}^{-1}$ in the south of Cameroon (Climate-Data.org, 2019). In all of the sites, precipitation occurs in a bimodal pattern, with typical wet seasons occurring from March to June and September to November (Fig. 1.2). The mean annual temperature across the three sites is $23.5^{\circ} \mathrm{C}$ (Fig. 1.2; ClimateData.org, 2019). 

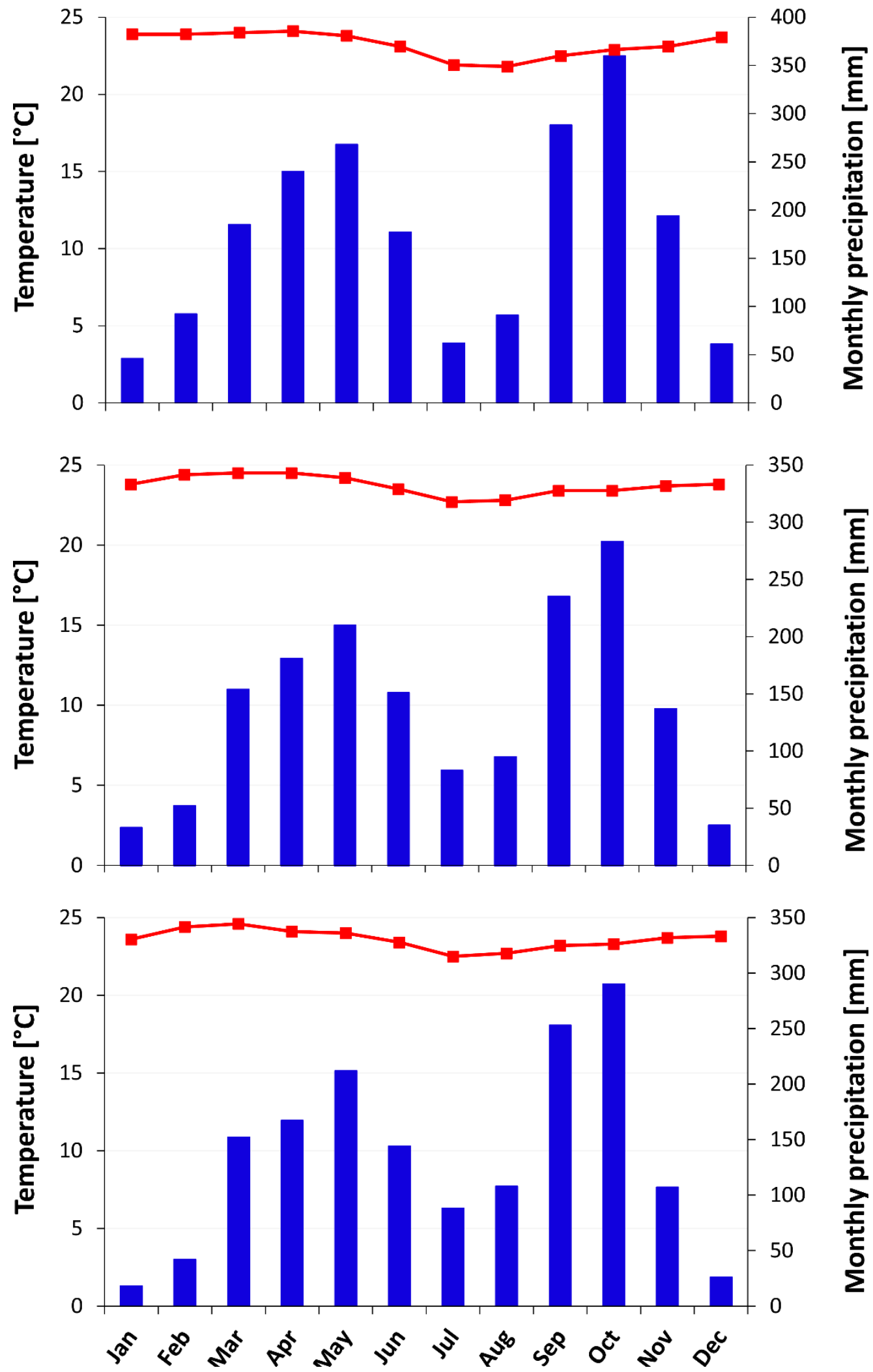

Figure 1. 2. Mean monthly temperature and precipitation (from 1982 to 2012) for Aloum (top panel), Biba Yezoum (centre panel), and Tomba (bottom panel) in southern and central regions of Cameroon (Data source: (Climate-Data.org, 2019). 
Prior to stem and soil trace gas flux measurements, we conducted a tree inventory in all the forests and cacao plots (Fig. 1.3) where all stems including cacao trees with a diameter at breast height $(\mathrm{DBH}) \geq 10 \mathrm{~cm}$ were identified and measured for $\mathrm{DBH}$. We identified 135 tree species belonging to 118 genera and 45 families in the natural forests. In the cacao agroforestry, we identified 89 shade tree species belonging to 77 genera and 33 families. The high number of species in the cacao agroforests signifies the high diversity and sustainability of these extensively managed farms.
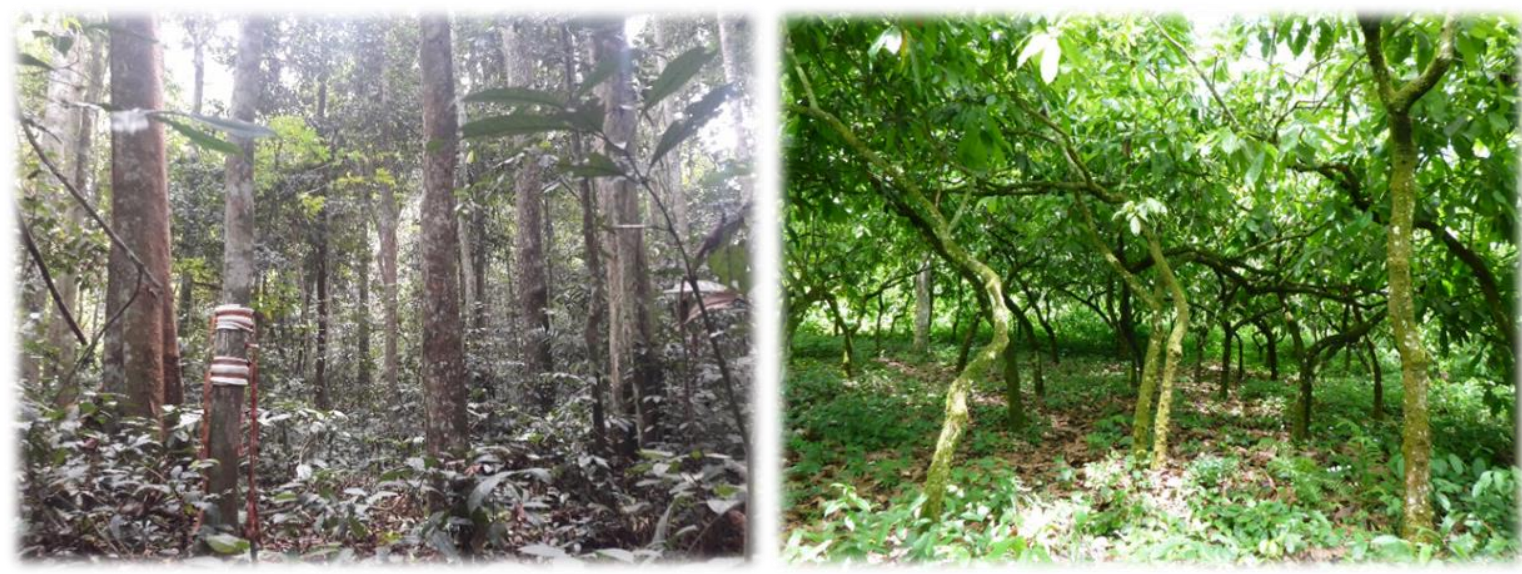

Figure 1. 3. Natural forests (left) and cacao agroforestry (right) in the Congo Basin, Cameroon.

For measurements of stem $\mathrm{N}_{2} \mathrm{O}$ and $\mathrm{CH}_{4}$ fluxes, we selected six cacao trees per replicate plot in the CAF, and six trees representing the most dominant species within each replicate plot in the forest. For soil trace gas flux measurements, we installed four permanent chamber bases per replicate plot, which were randomly distributed within the plot. Concurrent to the stem and soil $\mathrm{N}_{2} \mathrm{O}$-flux measurements, we measured soil temperature, soil water content, and extractable mineral $\mathrm{N}$ in the top 5-cm depth. We also sampled soil-air gas concentrations at 50-cm depth from permanently installed stainless-steel probes located at $\sim 1 \mathrm{~m}$ from the measured trees. We conducted trace gas flux measurements, soil and meteorological parameters in the inner 40-m 
x 40-m area within each plot to minimize edge effects (Fig. 1.4). Details on study area and experimental design are given in Chapters 2 and 3.

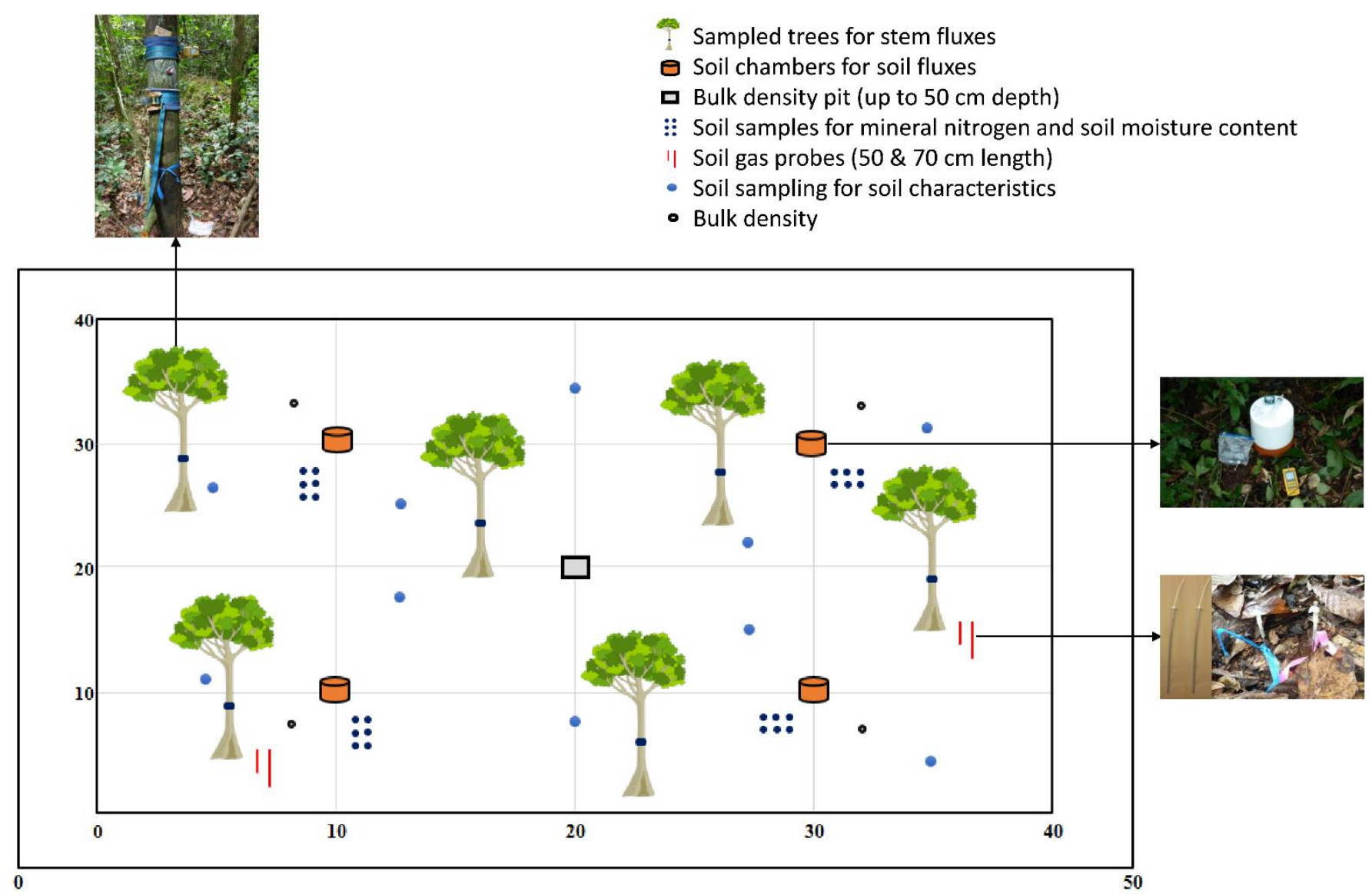

Figure 1. 4. Experimental layout of the stem and soil flux measurements in one of the replicate plots in the Congo Basin, Cameroon.

\subsection{References}

Allen, C. D., Macalady, A. K., Chenchouni, H., Bachelet, D., McDowell, N., Vennetier, M., et al. (2010). A global overview of drought and heat-induced tree mortality reveals emerging climate change risks for forests. Forest Ecology and Management, 259(4), 660-684. https://doi.org/10.1016/j.foreco.2009.09.001

Bae, K., Lee, D. K., Fahey, T. J., Woo, S. Y., Quaye, A. K., \& Lee, Y. K. (2013). Seasonal variation of soil respiration rates in a secondary forest and agroforestry systems. Agroforestry Systems, 87(1), 131-139. https://doi.org/10.1007/s10457-012-9530-8 
Beer, C., Reichstein, M., Tomelleri, E., Ciais, P., Martin, J., Carvalhais, N., et al. (2010). Terrestrial Gross Carbon Dioxide Uptake: Global Distribution and Covariation with Climate. Science, 329(August), 834-838. https://doi.org/https://doi.org/10.1126/science.1184984

Billand, A. (2012). Biodiversity in Central African forests: an overview of knowledge, main challenges and conservation measures. In C. de Wasseige, P. de Marcken, N. Bayol, 1 F. Hiol Hio, P. Mayaux, B. Desclée, et al. (Eds.), The forests of the Congo Basin-state of the forest 2010 (p. 276). Publications Office of the European Union. Luxembourg. https://doi.org/10.2788/47210

Bodelier, P. L. E., \& Laanbroek, H. J. (2004). Nitrogen as a regulatory factor of methane oxidation in soils and sediments. FEMS Microbiology Ecology, 47(3), 265-277. https://doi.org/10.1016/S0168-6496(03)00304-0

Bombelli, A., Henry, M., Castaldi, S., Adu-Bredu, S., Arneth, A., De Grandcourt, A., et al. (2009). An outlook on the Sub-Saharan Africa carbon balance. Biogeosciences, 6(10), 2193-2205. https://doi.org/10.5194/bg-6-2193-2009

Bouwman, A. F., Van Der Hoek, K. W., \& Olivier, J. G. J. (1995). Uncertainties in the global source distribution of nitrous oxide. Journal of Geophysical Research, 100(D2), 27852800. https://doi.org/10.1029/94JD02946

Breuer, L., Papen, H., \& Butterbach-Bahl, K. (2000). N2O emission from tropical forest soils of Australia. Journal of Geophysical Research Atmospheres, 105(D21), 26353-26367. https://doi.org/10.1029/2000JD900424

Buchel, H. B., \& Grosse, W. (1990). Localization of the porous partition responsible for pressurized gas transport in Alnus glutinosa (L.) Gaertn. Tree Physiology, 6(3), 247-256.

Butterbach-Bahl, K., Papen, H., \& Rennenberg, H. (1997). Impact of gas transport through rice cultivars on methane emission from rice paddy fields. Plant, Cell and Environment, 20(9), 1175-1183. https://doi.org/10.1046/j.1365-3040.1997.d01-142.x

Butterbach-Bahl, K., Baggs, E. M., Dannenmann, M., Kiese, R., \& Zechmeister-Boltenstern, S. (2013). Nitrous oxide emissions from soils: How well do we understand the processes and their controls? Philosophical Transactions of the Royal Society B: Biological Sciences, 368(1621). https://doi.org/10.1098/rstb.2013.0122

Cao, M., Zhang, Q., \& Shugart, H. H. (2001). Dynamic responses of African ecosystem carbon cycling to climate change. Climate Research, 17(2 SPECIAL 8), 183-193. https://doi.org/10.3354/cr017183

Chang, C., Janzen, H. H., Nakonechny, E. M., \& Cho, C. M. (1998). Nitrous Oxide Emission through Plants. Soil Science Society of America Journal, 62(1), 35-38.

https://doi.org/10.2136/sssaj1998.03615995006200010005x

Chen, X., Cabrera, M. L., Zhang, L., Wu, J., Shi, Y., Yu, W. T., \& Shen, S. M. (2002). Nitrous oxide emission from upland crops and crop-soil systems in northeastern China. Nutrient Cycling in Agroecosystems, 62(3), 241-247. https://doi.org/10.1023/A:1021202114354

Ciais, P., Bombelli, A., Williams, M., Piao, S. L., Chave, J., Ryan, C. M., et al. (2011). The carbon balance of Africa: Synthesis of recent research studies. Philosophical 
Transactions of the Royal Society A: Mathematical, Physical and Engineering Sciences, 369(1943), 2038-2057. https://doi.org/10.1098/rsta.2010.0328

Cicerone, R. J., \& Shetter, J. D. (1981). Sources of atmospheric methane: Measurements in rice paddies and a discussion. Journal of Geophysical Research, 86(8 C), 7203-7209. https://doi.org/10.1029/jc086ic08p07203

Climate-Data.org. (2019). Cameroon climate. Retrieved May 21, 2019, from https://en.climate-data.org/africa/cameroon-142/

Corre, M. D., Dechert, G., \& Veldkamp, E. (2006). Soil nitrogen cycling following montane forest conversion in Central Sulawesi, Indonesia. Soil Science Society of America Journal, 70(2), 359-366. https://doi.org/10.2136/sssaj2005.0061

Davidson, E. A., Keller, M., Erickson, H. E., Verchot, L. V., \& Veldkamp, E. (2000). Testing a Conceptual Model of Soil Emissions of Nitrous and Nitric Oxides. BioScience, 50(8), 667. https://doi.org/10.1641/0006-3568(2000)050[0667:tacmos]2.0.co;2

Dkamela, G. P. (2010). The context of REDD+ in Cameroon: Drivers, agents and institutions (Occasional). CIFOR, Bogor, Indonesia.

Dutaur, L., \& Verchot, L. V. (2007). A global inventory of the soil CH4 sink. Global Biogeochemical Cycles, 21(4), 1-9. https://doi.org/10.1029/2006GB002734

FAO. (2011). The State of Forests in the Amazon Basin, Congo Basin and Southeast Asia. A report prepared for the Summit of the Three Rainforest Basins Brazzaville, Republic of Congo. Rome, Italy, Italy.

Fisher, J. B., Sikka, M., Sitch, S., Ciais, P., Poulter, B., Galbraith, D., et al. (2013). African tropical rainforest net carbon dioxide fluxes in the twentieth century. Philosophical Transactions of the Royal Society B: Biological Sciences, 368(1625), 13-17. https://doi.org/10.1098/rstb.2012.0376

Forster, P., Ramaswamy, V., Artaxo, P., Berntsen, T., Betts, R., Fahey, D. W., et al. (2007). Changes in Atmospheric Constituents and in Radiative Forcing. In: Climate Change 2007: The Physical Science Basis. Contribution of Working Group I to the Fourth Assessment Report of the Intergovernmental Panel on Climate Change [Solomon, S., D. Qin, M. Ma. Cambridge, United Kingdom and New York, NY, USA, United Kingdom and New York, NY, USA: Cambridge University Press.

Gauci, V., Gowing, D. J. G., Hornibrook, E. R. C., Davis, J. M., \& Dise, N. B. (2010). Woody stem methane emission in mature wetland alder trees. Atmospheric Environment. https://doi.org/10.1016/j.atmosenv.2010.02.034

Hashimoto, S. (2012). A new estimation of global soil greenhouse gas fluxes using a simple data-oriented model. PLoS ONE, 7(8), 1-7. https://doi.org/10.1371/journal.pone.0041962

Hashimoto, S., Carvalhais, N., Ito, A., Migliavacca, M., Nishina, K., \& Reichstein, M. (2015). Global spatiotemporal distribution of soil respiration modeled using a global database. Biogeosciences, 12(13), 4121-4132. https://doi.org/10.5194/bg-12-4121-2015

Hassler, E., Corre, M. D., Tjoa, A., Damris, M., Utami, S. R., \& Veldkamp, E. (2015). Soil fertility controls soil-atmosphere carbon dioxide and methane fluxes in a tropical 
landscape converted from lowland forest to rubber and oil palm plantations.

Biogeosciences Discussions, 12(12), 9163-9207. https://doi.org/10.5194/bgd-12-91632015

Hassler, E., Corre, M. D., Kurniawan, S., \& Veldkamp, E. (2017). Soil nitrogen oxide fluxes from lowland forests converted to smallholder rubber and oil palm plantations in Sumatra, Indonesia. Biogeosciences, 14(11), 2781-2798. https://doi.org/https://doi.org/10.5194/bg-14-2781-2017

Hubau, W., Lewis, S. L., Phillips, O. L., Affum-Baffoe, K., Beeckman, H., Cuní-Sanchez, A., et al. (2020). Asynchronous carbon sink saturation in African and Amazonian tropical forests. Nature, 579(7797), 80-87. https://doi.org/10.1038/s41586-020-2035-0

Huntingford, C., Zelazowski, P., Galbraith, D., Mercado, L. M., Sitch, S., Fisher, R., et al. (2013). Simulated resilience of tropical rainforests to CO2 -induced climate change. Nature Geoscience, 6(4), 268-273. https://doi.org/10.1038/ngeo1741

IUSS Working Group WRB. (2015). World Reference Base for Soil Resources 2014, update 2015 International soil classification system for naming soils and creating legends for soil maps. World Soil Resources Reports No. 106. FAO, Rome.

Kesik, M., Blagodatsky, S., Papen, H., \& Butterbach-Bahl, K. (2006). Effect of pH, temperature and substrate on $\mathrm{N} 2 \mathrm{O}, \mathrm{NO}$ and $\mathrm{CO} 2$ production by Alcaligenes faecalis $\mathrm{p}$. Journal of Applied Microbiology, 101(3), 655-667. https://doi.org/10.1111/j.13652672.2006.02927.x

Kim, D. G., Thomas, A. D., Pelster, D. E., Rosenstock, T. S., \& Sanz-Cobena, A. (2016). Greenhouse gas emissions from natural ecosystems and agricultural lands in sub-Saharan Africa: Synthesis of available data and suggestions for further research. Biogeosciences, 13(16), 4789-4809. https://doi.org/10.5194/bg-13-4789-2016

Kirschke, S., Bousquet, P., Ciais, P., Saunois, M., Canadell, J. G., Dlugokencky, E. J., et al. (2013). Three decades of global methane sources and sinks. Nature Geoscience, 6(10), 813-823. https://doi.org/10.1038/ngeo1955

Kotto, J. S., Moukam, A., Njomgang, R., Tiki-Manga, T., Tonye, J., Diaw, C., et al. (2002). Alternatives to slash-and-burn in Indonesia: summary report \& synthesis of phase II in Cameroon. ASB-Indonesia report. Nairobi. Kenya.

Lewis, S. L., Lopez-Gonzalez, G., Sonké, B., Affum-Baffoe, K., Baker, T. R., Ojo, L. O., et al. (2009). Increasing carbon storage in intact African tropical forests. Nature, 457(7232), 1003-1006. https://doi.org/10.1038/nature07771

Luo, Y., \& Zhou, X. (2006). Soil Respiration and the Environment. Amsterdam, Netherlands, Netherlands: Academic Press. https://doi.org/https://doi.org/10.1016/B978-0-12-0887828.X5000-1

Machacova, K., Papen, H., Kreuzwieser, J., \& Rennenberg, H. (2013). Inundation strongly stimulates nitrous oxide emissions from stems of the upland tree Fagus sylvatica and the riparian tree Alnus glutinosa. Plant and Soil, 364(1-2), 287-301.

https://doi.org/10.1007/s11104-012-1359-4

Machacova, K., Bäck, J., Vanhatalo, A., Halmeenmäki, E., Kolari, P., Mammarella, I., et al. (2016). Pinus sylvestris as a missing source of nitrous oxide and methane in boreal 
forest. Scientific Reports, 6(March), 1-8. https://doi.org/10.1038/srep23410

Matson, A. L., Corre, M. D., Langs, K., \& Veldkamp, E. (2017). Soil trace gas fluxes along orthogonal precipitation and soil fertility gradients in tropical lowland forests of Panama. Biogeosciences, 14(14), 3509-3524. https://doi.org/10.5194/bg-14-3509-2017

Neubauer, S. C., \& Megonigal, J. P. (2015). Moving Beyond Global Warming Potentials to Quantify the Climatic Role of Ecosystems. Ecosystems, 18(6), 1000-1013. https://doi.org/10.1007/s10021-015-9879-4

Oertel, C., Matschullat, J., Zurba, K., Zimmermann, F., \& Erasmi, S. (2016). Greenhouse gas emissions from soils-A review. Chemie Der Erde, 76(3), 327-352. https://doi.org/10.1016/j.chemer.2016.04.002

Pangala, S. R., Moore, S., Hornibrook, E. R. C., \& Gauci, V. (2013). Trees are major conduits for methane egress from tropical forested wetlands. New Phytologist, 197(2), 524-531. https://doi.org/10.1111/nph.12031

Pangala, S. R., Gowing, D. J. G., Hornibrook, E. R. C., \& Gauci, V. (2014). Controls on methane emissions from Alnus glutinosa saplings. New Phytologist, 201(3), 887-896. https://doi.org/10.1111/nph.12561

Pangala, S. R., Hornibrook, E. R. C., Gowing, D. J. G., \& Gauci, V. (2015). The contribution of trees to ecosystem methane emissions in a temperate forested wetland. Global Change Biology, 21(7), 2642-2654. https://doi.org/10.1111/gcb.12891

Pangala, S. R., Enrich-Prast, A., Basso, L. S., Peixoto, R. B., Bastviken, D., Hornibrook, E. R. C., et al. (2017). Large emissions from floodplain trees close the Amazon methane budget. Nature, 552(7684), 230-234. https://doi.org/10.1038/nature24639

Perez, T., Trumbore, S. E., Tyler, S. C., Davidson, E. A., Keller, M., \& de Camargo, P. B. (2000). Isotopic variability of N2O emissions from tropical forest soils. Global Biogeochemical Cycles, 14(2), 525-535.

Pitz, S. L., \& Megonigal, J. P. (2017). Temperate forest methane sink diminished by tree emissions. New Phytologist, 214(4), 1432-1439. https://doi.org/10.1111/nph.14559

Pitz, S. L., Megonigal, J. P., Chang, C. H., \& Szlavecz, K. (2018). Methane fluxes from tree stems and soils along a habitat gradient. Biogeochemistry, 137(3), 307-320. https://doi.org/10.1007/s10533-017-0400-3

Raich, J. W., \& Potter, C. S. (1995). Global patterns of carbon dioxide emissions from soils. Global Biogeochemical Cycles, 9(1), 23-36. https://doi.org/10.1029/94GB02723

Raich, J. W., \& Schlesinger, W. H. (1998). The global carbon dioxide flux in soil respiration and its relationship to vegetation and climate. Tellus $B, 44 B, 81-99$.

Richardson, A. D., Hollinger, D. Y., Shoemaker, J. K., Hughes, H., Savage, K., \& Davidson, E. A. (2019). Six years of ecosystem-atmosphere greenhouse gas fluxes measured in a sub-boreal forest. Scientific Data, 6(1), 117. https://doi.org/10.1038/s41597-019-0119-1

Rusch, H., \& Rennenberg, H. (1998). Black alder (Alnus glutinosa (L.) Gaertn.) trees mediate methane and nitrous oxide emission from the soil to the atmosphere. Plant and Soil, 201(1), 1-7. https://doi.org/10.1023/A:1004331521059 
Saj, S., Jagoret, P., \& Todem Ngogue, H. (2013). Carbon storage and density dynamics of associated trees in three contrasting Theobroma cacao agroforests of Central Cameroon. Agroforestry Systems, 87(6), 1309-1320. https://doi.org/10.1007/s10457-013-9639-4

Saunois, M., Bousquet, P., Poulter, B., Peregon, A., Ciais, P., Canadell, J. G., et al. (2016). The global methane budget 2000-2012. Earth System Science Data, 8(2), 697-751. https://doi.org/10.5194/essd-8-697-2016

Schlesinger, W. H., \& Bernhardt, E. S. (2013). Biogeochemistry: an analysis of global change. San Diego, CA, USA, CA, USA: Academic Press.

Schütz, H., Schröder, P., \& Rennenberg, H. (1991). Role of plants in regulation the methane flux to the atmosphere. In T. D. Sharkey, E. A. Holland, \& A. H. Mooney (Eds.), In Trace Gas Emissions by Plants (pp. 29-63). San Diego, CA, USA: Academic Press.

Singh, S., \& Singh, J. S. (1995). Plants as conduits for methane in wetlands. Proc. National Academy of Sciences India, 65 (B)(II), 147-157.

Stehfest, E., \& Bouwman, L. (2006). N2O and NO emission from agricultural fields and soils under natural vegetation: Summarizing available measurement data and modeling of global annual emissions. Nutrient Cycling in Agroecosystems, 74(3), 207-228. https://doi.org/10.1007/s10705-006-9000-7

Syakila, A., \& Kroeze, C. (2011). The global nitrous oxide budget revisited. Greenhouse Gas Measurement and Management, 1(1), 17-26. https://doi.org/10.3763/ghgmm.2010.0007

Terazawa, K., Yamada, K., Ohno, Y., Sakata, T., \& Ishizuka, S. (2015). Spatial and temporal variability in methane emissions from tree stems of Fraxinus mandshurica in a cooltemperate floodplain forest. Biogeochemistry, 123(3), 349-362.

https://doi.org/10.1007/s10533-015-0070-y

Thompson, R. L., Chevallier, F., Crotwell, A. M., Dutton, G., Langenfelds, R. L., Prinn, R. G., et al. (2014). Nitrous oxide emissions 1999 to 2009 from a global atmospheric inversion. Atmospheric Chemistry and Physics, 14(4), 1801-1817. https://doi.org/10.5194/acp-14-1801-2014

Tyukavina, A., Hansen, M. C., Potapov, P., Parker, D., Okpa, C., Stehman, S. V., et al. (2018). Congo Basin forest loss dominated by increasing smallholder clearing. Science Advances, 4(11). https://doi.org/10.1126/sciadv.aat2993

Valentini, R., Arneth, A., Bombelli, A., Castaldi, S., Cazzolla Gatti, R., Chevallier, F., et al. (2014). A full greenhouse gases budget of africa: Synthesis, uncertainties, and vulnerabilities. Biogeosciences, 11(2), 381-407. https://doi.org/10.5194/bg-11-381-2014

Veldkamp, E., \& Keller, M. (1997). Nitrogen oxide emissions from a banana plantation in the humid tropics. Journal of Geophysical Research, 102(D13), 15889-15898.

Veldkamp, E., Purbopuspito, J., Corre, M. D., Brumme, R., \& Murdiyarso, D. (2008). Land use change effects on trace gas fluxes in the forest margins of Central Sulawesi, Indonesia. Journal of Geophysical Research: Biogeosciences, 113(2), 1-11. https://doi.org/10.1029/2007JG000522

Veldkamp, E., Koehler, B., \& Corre, M. D. (2013). Indications of nitrogen-limited methane uptake in tropical forest soils. Biogeosciences, 10(8), 5367-5379. 
https://doi.org/10.5194/bg-10-5367-2013

Verbeeck, H., Boeckx, P., \& Steppe, K. (2011). Tropical forests : include Congo basin. Nature, 479(179), 2011. https://doi.org/https://doi.org/10.1038/479179b

Verchot, L. V., Davidson, E. A., Cattânio, J. H., \& Ackerman, I. L. (2000). Land-use change and biogeochemical controls of methane fluxes in soils of eastern Amazonia. Ecosystems, 3(1), 41-56. https://doi.org/10.1007/s100210000009

Washington, R., James, R., Pearce, H., Pokam, W. M., \& Moufouma-Okia, W. (2013). Congo basin rainfall climatology: Can we believe the climate models? Philosophical Transactions of the Royal Society B: Biological Sciences, 368(1625). https://doi.org/10.1098/rstb.2012.0296

Welch, B., Gauci, V., \& Sayer, E. J. (2019). Tree stem bases are sources of CH4 and N2O in a tropical forest on upland soil during the dry to wet season transition. Global Change Biology, 25(1), 361-372. https://doi.org/10.1111/gcb.14498

Wen, Y., Corre, M. D., Rachow, C., Chen, L., \& Veldkamp, E. (2017). Nitrous oxide emissions from stems of alder, beech and spruce in a temperate forest. Plant Soil. https://doi.org/10.1007/s11104-017-3416-5

Werner, C., Butterbach-Bahl, K., Haas, E., Hickler, T., \& Kiese, R. (2007). A global inventory of $\mathrm{N} 2 \mathrm{O}$ emissions from tropical rainforest soils using a detailed biogeochemical model. Global Biogeochemical Cycles, 21(3). https://doi.org/10.1029/2006GB002909

Yu, K. W., Wang, Z. P., \& Chen, G. X. (1997). Nitrous oxide and methane transport through rice plants. Biology and Fertility of Soils, 24(3), 341-343. https://doi.org/10.1007/s003740050254 


\section{CHAPTER 2}

STEM AND SOIL NITROUS OXIDE FLUXES FROM RAINFOREST AND CACAO AGROFOREST ON HIGHLY WEATHERED SOILS IN THE CONGO BASIN

Under review in EGU Biogeosciences

Najeeb A. Iddris ${ }^{1}$, Marife D. Corre ${ }^{1}$, Martin Yemefack ${ }^{2,3}$, Oliver van Straaten ${ }^{1,4}$, Edzo Veldkamp $^{1}$

${ }^{1}$ Soil Science of Tropical and Subtropical Ecosystems, University of Goettingen, Goettingen, Germany

${ }^{2}$ International Institute of Tropical Agriculture, Yaoundé, Cameroon

${ }^{3}$ Now at: Sustainable Tropical Solutions (STS), Yaoundé, Cameroon

${ }^{4}$ Now at: Northwest German Forest Research Institute, Goettingen, Germany 


\subsection{Abstract}

Although tree stems act as conduits for greenhouse gases (GHG) produced in the soil, the magnitudes of tree contributions to total (soil + stem) nitrous oxide $\left(\mathrm{N}_{2} \mathrm{O}\right)$ emissions from tropical rainforests on heavily weathered soils remain unknown. Moreover, soil GHG fluxes are largely understudied in African rainforests, and the effects of land-use change on these gases are identified as an important research gap in the global GHG budget. In this study, we quantified the changes in stem and soil $\mathrm{N}_{2} \mathrm{O}$ fluxes with forest conversion to cacao agroforestry. Stem and soil $\mathrm{N}_{2} \mathrm{O}$ fluxes were measured monthly for a year (2017-2018) in four replicate plots per land use at three sites across central and southern Cameroon. Tree stems consistently emitted $\mathrm{N}_{2} \mathrm{O}$ throughout the measurement period, and were positively correlated with soil $\mathrm{N}_{2} \mathrm{O}$ fluxes. ${ }^{15} \mathrm{~N}$-isotope tracing from soil mineral $\mathrm{N}$ to stem-emitted ${ }^{15} \mathrm{~N}_{2} \mathrm{O}$ as well as correlations between temporal patterns of stem $\mathrm{N}_{2} \mathrm{O}$ emissions, soil-air $\mathrm{N}_{2} \mathrm{O}$ concentration, soil $\mathrm{N}_{2} \mathrm{O}$ emissions, and vapor pressure deficit suggest that $\mathrm{N}_{2} \mathrm{O}$ emitted by the stems originated predominantly from $\mathrm{N}_{2} \mathrm{O}$ produced in the soil. Forest conversion to extensively managed, mature (>20 years old) cacao agroforestry had no effect on stem and soil $\mathrm{N}_{2} \mathrm{O}$ fluxes. The annual total $\mathrm{N}_{2} \mathrm{O}$ emissions were $1.55 \pm 0.20 \mathrm{~kg} \mathrm{~N} \mathrm{ha}^{-1} \mathrm{yr}^{-1}$ from the forest and $1.15 \pm 0.10 \mathrm{~kg} \mathrm{~N} \mathrm{ha}^{-1}$ $\mathrm{yr}^{-1}$ from cacao agroforestry, with tree $\mathrm{N}_{2} \mathrm{O}$ emissions contributing 11 to $38 \%$ for forests and 8 to $15 \%$ for cacao agroforestry. These substantial contributions of tree stems to total $\mathrm{N}_{2} \mathrm{O}$ emissions highlight the importance of including tree-mediated fluxes in ecosystem GHG budgets. Taking into account that our study sites' biophysical characteristics represented twothirds of the humid rainforests in the Congo Basin, we estimated a total $\mathrm{N}_{2} \mathrm{O}$ source strength for this region of $0.18 \pm 0.05 \mathrm{Tg} \mathrm{N}_{2} \mathrm{O}-\mathrm{N} \mathrm{yr}^{-1}$.

Keywords: Africa, cacao agroforest, Congo Basin, Ferralsol, land-use change, nitrous oxide, Oxisol, soil $\mathrm{N}_{2} \mathrm{O}$ emissions, stem $\mathrm{N}_{2} \mathrm{O}$ emissions, tropical rainforest 


\subsection{Introduction}

The trace gas nitrous oxide $\left(\mathrm{N}_{2} \mathrm{O}\right)$ has become the main stratospheric ozone depleting substance produced by human activities (Ravishankara et al., 2009), and is after carbon dioxide and methane $\left(\mathrm{CH}_{4}\right)$ the most important anthropogenic greenhouse gas (GHG) (Denman et al., 2007). Humid tropical soils are considered one of the most important global $\mathrm{N}_{2} \mathrm{O}$ sources (Denman et al., 2007; Werner et al., 2007a), with tropical rainforests alone estimated to contribute between 0.9 to $4.5 \mathrm{Tg} \mathrm{N}_{2} \mathrm{O}-\mathrm{N} \mathrm{yr}^{-1}$ to the global $\mathrm{N}_{2} \mathrm{O}$ source of about $16 \mathrm{Tg} \mathrm{N}_{2} \mathrm{O}-\mathrm{N}$ $\mathrm{yr}^{-1}$ (Bouwman et al., 1995; Breuer et al., 2000; Werner et al., 2007a). However, ground-based, bottom-up $\mathrm{N}_{2} \mathrm{O}$ emission estimates appear to be in stark contrast to the high emissions estimated from top-down approaches such as modelling and global $\mathrm{N}_{2} \mathrm{O}$ atmospheric inversions (Huang et al., 2008; Thompson et al., 2014). Nevertheless, there exists considerable uncertainty in both approaches (Davidson \& Kanter, 2014), especially for the tropics (Valentini et al., 2014). Recent studies suggest two possible reasons for large uncertainties in bottom-up approaches: “missing" emission pathways such as trees (Welch et al., 2019), and a strong geographic bias of measured $\mathrm{N}_{2} \mathrm{O}$ fluxes from tropical forests.

Most of the studies on soil $\mathrm{N}_{2} \mathrm{O}$ fluxes from tropical ecosystems were conducted in South and Central America (Davidson \& Verchot, 2000; Neill et al., 2005; Wolf et al., 2011; Matson et al., 2017), tropical Asia (Purbopuspito et al., 2006; Verchot et al., 2006; Werner et al., 2006; Veldkamp et al., 2008; Hassler et al., 2017) and Australia (Breuer et al., 2000; Kiese et al., 2003). Africa remains the continent with the least published field studies on soil $\mathrm{N}_{2} \mathrm{O}$ fluxes from the tropical forest biome. After the pioneering work by Serca et al. (1994), very few field studies have been conducted, most of which were either not replicated with independent plots or only with short measurement campaigns (Werner et al., 2007b; Castaldi et al., 2013; Gütlein et al., 2018; Wanyama et al., 2018). The remaining studies were based on laboratory incubations, which cannot be translated to actual field conditions. Consequently, 
field-based studies with sufficient spatial and temporal coverage are critical for improving the highly uncertain $\mathrm{N}_{2} \mathrm{O}$ sink and source estimates for Africa (Valentini et al., 2014; Kim et al., 2016b).

The Congo Basin is the second largest intact tropical forest in the world and constitutes one of the most important carbon (C) and biodiversity reservoirs globally. Behind the DR Congo, Cameroon is the second highest deforested country in the Congo Basin with about $75 \%$ of its forest being subject to pressure from other land uses including agroforestry (Dkamela, 2010). Conversion of forests to traditional cacao agroforestry (CAF) systems have well been documented in Cameroon (Zapfack et al., 2002; Sonwa et al., 2007; Abada Mbolo et al., 2016). Presently, an estimated 400,000 hectares is under CAF on small family farms of approximately one to three hectares (Kotto et al., 2002; Saj et al., 2013). These CAF systems are commonly established under the shade of the forests' remnant trees, and are characterised by absence of fertilizer inputs and low yields of up to $1 \mathrm{t}$ cacao beans ha-1 (Saj et al., 2013).

Changes in land use have been found to affect soil $\mathrm{N}_{2} \mathrm{O}$ emissions due to changes in soil $\mathrm{N}$ availability (Corre et al., 2006), vegetation (Veldkamp et al., 2008) and management practices such as $\mathrm{N}$ fertilization (Hassler et al., 2017). In particular, unfertilized agroforestry and agricultural systems have been found to have comparable $\mathrm{N}_{2} \mathrm{O}$ fluxes as those from the reference forests (Hassler et al., 2017), whereas $\mathrm{N}$-fertilized systems tend to have higher $\mathrm{N}_{2} \mathrm{O}$ fluxes than the previous forest due to elevated soil mineral $\mathrm{N}$ following fertilization (Verchot et al., 2006). This is in line with postulations of the conceptual hole-in-the-pipe (HIP) model, which suggest that the magnitude of $\mathrm{N}_{2} \mathrm{O}$ emissions from the soil are largely controlled first by soil $\mathrm{N}$ availability and second by soil water content (Davidson et al., 2000a). As the number of studies on soil GHG fluxes from agricultural land uses in Africa is still limited, the effect of 
land-use change on GHG fluxes is identified as an important research gap in the GHG budget of Africa (Valentini et al., 2014).

Tree stems have been found to act as conduits for soil $\mathrm{N}_{2} \mathrm{O}$ in wetlands, mangroves and well-drained forests (Rusch \& Rennenberg, 1998; Kreuzwieser et al., 2003; Welch et al., 2019), facilitating the transport from the soil, where $\mathrm{N}_{2} \mathrm{O}$ are produced or consumed by microbial nitrification and denitrification processes, to the atmosphere. Findings of strong declines in $\mathrm{N}_{2} \mathrm{O}$ emissions with increasing stem height (Díaz-Pinés et al., 2016; Wen et al., 2017; Barba et al., 2019 b) suggest that $\mathrm{N}_{2} \mathrm{O}$ is mainly emitted through the stems and less likely through the leaves. Trees adapted to wetlands and mangroves have aerenchyma systems through which $\mathrm{N}_{2} \mathrm{O}$ can be transported from the soil into the tree by both gas diffusion and transpiration stream, with exchange to the atmosphere predominantly through the stem lenticels (Rusch \& Rennenberg, 1998; Wen et al., 2017). However, for trees on well-drained soils, a different transport mechanism appears to be dominant: transpiration causes the xylem sap flow in which dissolved $\mathrm{N}_{2} \mathrm{O}$ is transported from the soil to the tree and emitted to the atmosphere through the stem surface and stomata (Machacova et al., 2013; Wen et al., 2017). Recent evidence shows that trees can also act as $\mathrm{N}_{2} \mathrm{O}$ sinks (Machacova et al., 2017; Barba et al., 2019b), highlighting the need for further research of the stem $\mathrm{N}_{2} \mathrm{O}$ flux magnitudes and their mechanisms.

The most important soil parameters found to influence tree-stem $\mathrm{N}_{2} \mathrm{O}$ fluxes include soil water content (Rusch \& Rennenberg, 1998; Machacova et al., 2016), soil $\mathrm{N}_{2} \mathrm{O}$ fluxes (DíazPinés et al., 2016; Wen et al., 2017), soil temperature (Machacova et al., 2013) and soil-air $\mathrm{N}_{2} \mathrm{O}$ concentration within the rooting zone (Wen et al., 2017). These studies also reported environmental parameters, such as air temperature and vapour pressure deficit (VPD), to drive stem $\mathrm{N}_{2} \mathrm{O}$ fluxes due to their influence on transpiration (O'Brien et al., 2004). For temperate forests on a well-drained soil, annual stem $\mathrm{N}_{2} \mathrm{O}$ fluxes have been found to contribute up to $10 \%$ 
of the ecosystem $\mathrm{N}_{2} \mathrm{O}$ emissions (Wen et al., 2017). However, until now, there is no groundbased spatial extrapolation of the contribution of stem $\mathrm{N}_{2} \mathrm{O}$ emissions from tropical forests on well-drained soils. Hence, there is a need for concurrent quantifications of the contributions of stem and soil $\mathrm{N}_{2} \mathrm{O}$ fluxes so as to provide insights on the source strengths of $\mathrm{N}_{2} \mathrm{O}$ emissions from tropical African land uses and to improve estimates of $\mathrm{N}_{2} \mathrm{O}$ emissions from the region.

Our present study addresses these knowledge gaps by providing year-round measurements of stem and soil $\mathrm{N}_{2} \mathrm{O}$ fluxes from forests and converted $\mathrm{CAF}$ systems with spatially replicated plots in the Congo Basin as well as stem $\mathrm{N}_{2} \mathrm{O}$ fluxes of 23 tree species that have not been measured before. Our study aimed to (i) assess whether trees in tropical rainforests and $\mathrm{CAF}$ are important conduits of $\mathrm{N}_{2} \mathrm{O}$, (ii) quantify changes in soil-atmosphere $\mathrm{N}_{2} \mathrm{O}$ fluxes with forest conversion to $\mathrm{CAF}$, and (iii) determine the temporal and spatial controls of stem and soil $\mathrm{N}_{2} \mathrm{O}$ fluxes. We hypothesized that (i) stem and soil $\mathrm{N}_{2} \mathrm{O}$ fluxes from these extensively managed CAF systems (unfertilized and manual harvest) will be comparable to the natural forests, and (ii) the seasonal pattern of stem emissions will parallel that of soil $\mathrm{N}_{2} \mathrm{O}$ emissions and both will have similar soil and climatic controlling factors.

\subsection{Materials and methods}

\subsubsection{Study area and experimental design}

Our study was conducted at three study sites located in southern and central Cameroon, where natural forests are predominantly converted to CAF (Sonwa et al., 2007). Sites in the southern region were located around the villages of Aloum $\left(2.813^{\circ} \mathrm{N}, 10.719^{\circ} \mathrm{E} ; 651 \mathrm{~m}\right.$ above sea level, asl) and Biba Yezoum $\left(3.158^{\circ} \mathrm{N}, 12.292^{\circ} \mathrm{E} ; 674 \mathrm{~m}\right.$ asl $)$, and the third site was located around the village of Tomba $\left(3.931^{\circ} \mathrm{N}, 12.430^{\circ} \mathrm{E} ; 752 \mathrm{~m}\right.$ asl) in the central region (Fig. 1.1). The mean annual air temperature across the three sites is $23.5^{\circ} \mathrm{C}$ (Climate-Data.org, 2019), and the soil temperature ranged from $21.6-24.4{ }^{\circ} \mathrm{C}$ during our measurement period from May 2017 to April 
2018. The study sites span an annual precipitation from $1576 \mathrm{~mm} \mathrm{yr}^{-1}$ in the centre to $2064 \mathrm{~mm}$ $\mathrm{yr}^{-1}$ in the south of Cameroon (Table S2.1; Climate-Data.org, 2019). Precipitation occurs in a bimodal pattern, with two dry seasons $(<120 \mathrm{~mm}$ monthly rainfall) occurring from July to August and December to February (Fig. 1.2). All sites are situated on heavily weathered soils classified as Ferralsols (IUSS WRB, 2015). Geologically, Tomba and Biba Yezoum are underlain by middle to superior Precambrian basement rocks, made up of metamorphic schists, phyllites and quartzites, whereas Aloum site is situated on inferior Precambrian basement rocks, made up of inferior gneiss and undifferentiated gneiss (Gwanfogbe et al., 1983).

At each site, we studied two land-use systems: the reference forest and the converted CAF system. Additional information on vegetation and site characteristics are reported in Table S2.1. These CAF sites were established right after clearing the natural forests, where remnant forest trees were retained by farmers to provide shade for understorey cacao trees (Theobroma cacao). Cacao planting and localised weeding were all done manually using hand tools. Surveys from farm owners indicated that there had been no mineral fertilization in any of the CAF sites. The ages of the CAF since conversion varied between 22 and $~ 45$ years.

We selected four replicate plots $(50 \mathrm{~m}$ x $50 \mathrm{~m}$ each with a minimum distance of $100 \mathrm{~m}$ between plots) per land-use type within each site (Fig. 1.1), totalling to 24 plots that were all located on relatively flat topography. Within each plot, all stems including cacao trees with a diameter at breast height $(\mathrm{DBH}) \geq 10 \mathrm{~cm}$ were identified and measured for $\mathrm{DBH}$ and height. We conducted $\mathrm{N}_{2} \mathrm{O}$ flux measurements, soil and meteorological parameters in the inner $40-\mathrm{m}$ $\times 40-\mathrm{m}$ area within each plot to minimize edge effects. To check that soil conditions were comparable between the reference forests and converted CAF, we compared a land-useindependent soil characteristic, i.e. clay content at 30-50 cm depth, between these land uses at each site. Since we did not find significant differences in clay contents between the forest and 
CAF at each of the sites (Table 2.1), we inferred that land-use types within each site had comparable initial soil characteristics prior to conversion and any differences in $\mathrm{N}_{2} \mathrm{O}$ fluxes and soil controlling factors can be attributed to land-use conversion.

For measurements of stem $\mathrm{N}_{2} \mathrm{O}$ fluxes, we selected six cacao trees per replicate plot in the $\mathrm{CAF}$, and six trees representing the most dominant species within each replicate plot in the forest, based on their importance value index (IVI) (Table S2.1). The species IVI is a summation of the relative density, relative frequency and relative dominance of the tree species (Curtis \& McIntosh, 1951). For a given species, the relative density refers to its total number of individuals in the four forest plots at each site; the relative frequency refers to its occurrence among the four forest plots; and the relative dominance refers to its total basal area in the four forest plots, all expressed as percentages of all species. These 24 trees measured at each site (6 trees $\times 4$ forest plots) included nine species in Aloum site, seven species in Biba Yezoum site, and 10 species in Tomba site (species are specified in Fig. 2.1). The trees were measured for stem $\mathrm{N}_{2} \mathrm{O}$ fluxes at $1.3 \mathrm{~m}$ height above the ground at monthly interval from May 2017 to April 2018. Furthermore, we assessed the influence of tree height on stem $\mathrm{N}_{2} \mathrm{O}$ fluxes by conducting additional measurements on 16 individual trees per land use in May 2018; these trees were included in the monthly measurements but were additionally measured at three stem heights $(1.3 \mathrm{~m}, 2.6 \mathrm{~m}$ and $3.9 \mathrm{~m}$ from the ground) per tree in the forest, and at two heights $(1.3 \mathrm{~m}$ and $2.6 \mathrm{~m}$ ) per tree in the CAF due to the limited height of the cacao trees.

For soil $\mathrm{N}_{2} \mathrm{O}$ flux measurements, we installed four permanent chamber bases per replicate plot, which were randomly distributed within the inner 40-m $\times 40-\mathrm{m}$ area. We conducted monthly measurements of soil $\mathrm{N}_{2} \mathrm{O}$ fluxes from May 2017 to April 2018 as well as meteorological and soil variables known to control $\mathrm{N}_{2} \mathrm{O}$ emission (see below). 
Table 2.1. Mean $( \pm \mathrm{SE}, n=4)$ soil biochemical characteristics in the top 50 - $\mathrm{cm}^{\dagger}$ depth in forest and cacao agroforestry $(\mathrm{CAF})$ within each site in the Congo Basin, Cameroon. Means followed by different lowercase letters indicate significant differences between land-use types within each site and different capital letters indicate significant differences among the three sites within a land-use type (Anova with Fisher's LSD test or KruskalWallis ANOVA with multiple comparison extension test at $p \leq 0.05$ ).

\begin{tabular}{|c|c|c|c|c|c|c|}
\hline \multirow[t]{2}{*}{$\begin{array}{l}\text { Soil } \\
\text { characteristics }\end{array}$} & \multicolumn{2}{|l|}{ Aloum site } & \multicolumn{2}{|c|}{ Biba Yezoum site } & \multicolumn{2}{|l|}{ Tomba site } \\
\hline & Forest & CAF & Forest & CAF & Forest & CAF \\
\hline Clay $(30-50 \mathrm{~cm})(\%)$ & $66.0 \pm 2.4^{\mathrm{a}, \mathrm{A}}$ & $59.3 \pm 6.1^{\mathrm{a}, \mathrm{A}}$ & $32.8 \pm 9.4^{\mathrm{a}, \mathrm{B}}$ & $39.5 \pm 0.9^{\mathrm{a}, \mathrm{B}}$ & $55.3 \pm 0.5^{\mathrm{a}, \mathrm{AB}}$ & $51.8 \pm 1.1^{\mathrm{a}, \mathrm{AB}}$ \\
\hline $\begin{array}{l}\text { Bulk density } \\
\left(\mathrm{g} \mathrm{cm}^{-3}\right)\end{array}$ & $1.2 \pm 0.1^{\mathrm{a}, \mathrm{A}}$ & $1.2 \pm 0.1^{\mathrm{a}, \mathrm{A}}$ & $1.2 \pm 0.1^{\mathrm{a}, \mathrm{A}}$ & $1.2 \pm 0.1^{\mathrm{a}, \mathrm{A}}$ & $1.2 \pm 0.1^{\mathrm{a}, \mathrm{A}}$ & $1.2 \pm 0.1^{\mathrm{a}, \mathrm{A}}$ \\
\hline $\mathrm{pH}\left(1: 4 \mathrm{H}_{2} \mathrm{O}\right)$ & $3.7 \pm 0.0^{\mathrm{b}, \mathrm{A}}$ & $4.1 \pm 0.1^{\mathrm{a}, \mathrm{A}}$ & $3.7 \pm 0.1^{\mathrm{b}, \mathrm{A}}$ & $4.6 \pm 0.2^{\mathrm{a}, \mathrm{A}}$ & $3.6 \pm 0.0^{\mathrm{b}, \mathrm{A}}$ & $4.5 \pm 0.2^{\mathrm{a}, \mathrm{A}}$ \\
\hline${ }^{15} \mathrm{~N}$ natural abundance $(\%)$ & $8.4 \pm 0.2^{\mathrm{b}, \mathrm{A}}$ & $10.2 \pm 0.1^{\mathrm{a}, \mathrm{A}}$ & $8.6 \pm 0.2^{\mathrm{a}, \mathrm{A}}$ & $9.1 \pm 0.2^{\mathrm{a}, \mathrm{B}}$ & $8.8 \pm 0.1^{\mathrm{a}, \mathrm{A}}$ & $8.8 \pm 0.1^{\mathrm{a}, \mathrm{B}}$ \\
\hline Soil organic $\mathrm{C}\left(\mathrm{kg} \mathrm{C} \mathrm{m}^{-2}\right)$ & $12.1 \pm 0.4^{\mathrm{a}, \mathrm{A}}$ & $6.7 \pm 0.2^{\mathrm{b}, \mathrm{A}}$ & $7.2 \pm 0.9^{\mathrm{a}, \mathrm{B}}$ & $5.6 \pm 0.7^{\mathrm{a}, \mathrm{A}}$ & $9.8 \pm 0.2^{\mathrm{a}, \mathrm{AB}}$ & $7.1 \pm 0.4^{\mathrm{b}, \mathrm{A}}$ \\
\hline Total $\mathrm{N}\left(\mathrm{kg} \mathrm{N} \mathrm{m}^{-2}\right)$ & $1.1 \pm 0.1^{\mathrm{a}, \mathrm{A}}$ & $0.7 \pm 0.0^{\mathrm{b}, \mathrm{A}}$ & $0.7 \pm 0.1^{\mathrm{a}, \mathrm{A}}$ & $0.5 \pm 0.0^{\mathrm{a}, \mathrm{B}}$ & $0.9 \pm 0.0^{\mathrm{a}, \mathrm{A}}$ & $0.7 \pm 0.0^{\mathrm{b}, \mathrm{A}}$ \\
\hline $\operatorname{ECEC~}\left(\mathrm{mmol}_{\mathrm{c}} \mathrm{kg}^{-1}\right)$ & $57.5 \pm 3.9^{\mathrm{a}, \mathrm{A}}$ & $33.9 \pm 2.8^{\mathrm{b}, \mathrm{A}}$ & $49.1 \pm 11.3^{\mathrm{a}, \mathrm{A}}$ & $41.1 \pm 7.2^{\mathrm{a}, \mathrm{A}}$ & $58.5 \pm 2.0^{\mathrm{a}, \mathrm{A}}$ & $46.8 \pm 4.7^{\mathrm{a}, \mathrm{A}}$ \\
\hline Exch. bases $\left(\mathrm{mmol}_{\mathrm{c}} \mathrm{kg}^{-1}\right)$ & $3.5 \pm 0.3^{\mathrm{b}, \mathrm{B}}$ & $8.7 \pm 1.7^{\mathrm{a}, \mathrm{B}}$ & $8.5 \pm 1.1^{\mathrm{b}, \mathrm{A}}$ & $31.0 \pm 8.5^{\mathrm{a}, \mathrm{A}}$ & $9.3 \pm 0.8^{\mathrm{b}, \mathrm{A}}$ & $30.4 \pm 7.6^{\mathrm{a}, \mathrm{A}}$ \\
\hline Exchangeable $\mathrm{Al}\left(\mathrm{mmol}_{\mathrm{c}} \mathrm{kg}^{-1}\right)$ & $47.3 \pm 3.1^{\mathrm{a}, \mathrm{A}}$ & $20.9 \pm 3.5^{\mathrm{b}, \mathrm{A}}$ & $32.9 \pm 8.9^{\mathrm{a}, \mathrm{A}}$ & $5.4 \pm 1.2^{\mathrm{b}, \mathrm{B}}$ & $39.2 \pm 2.3^{\mathrm{a}, \mathrm{A}}$ & $12.3 \pm 2.7^{\mathrm{b}, \mathrm{AB}}$ \\
\hline
\end{tabular}

$\dagger$ Values are depth-weighted average, except for clay content $(30-50 \mathrm{~cm})$ and stocks of soil organic $\mathrm{C}$ and total $\mathrm{N}$, which are sum of the entire 50 cm depth. Abbreviations: ECEC, effective cation exchange capacity; Exch. bases: sum of exchangeable Ca, Mg, K, Na. 

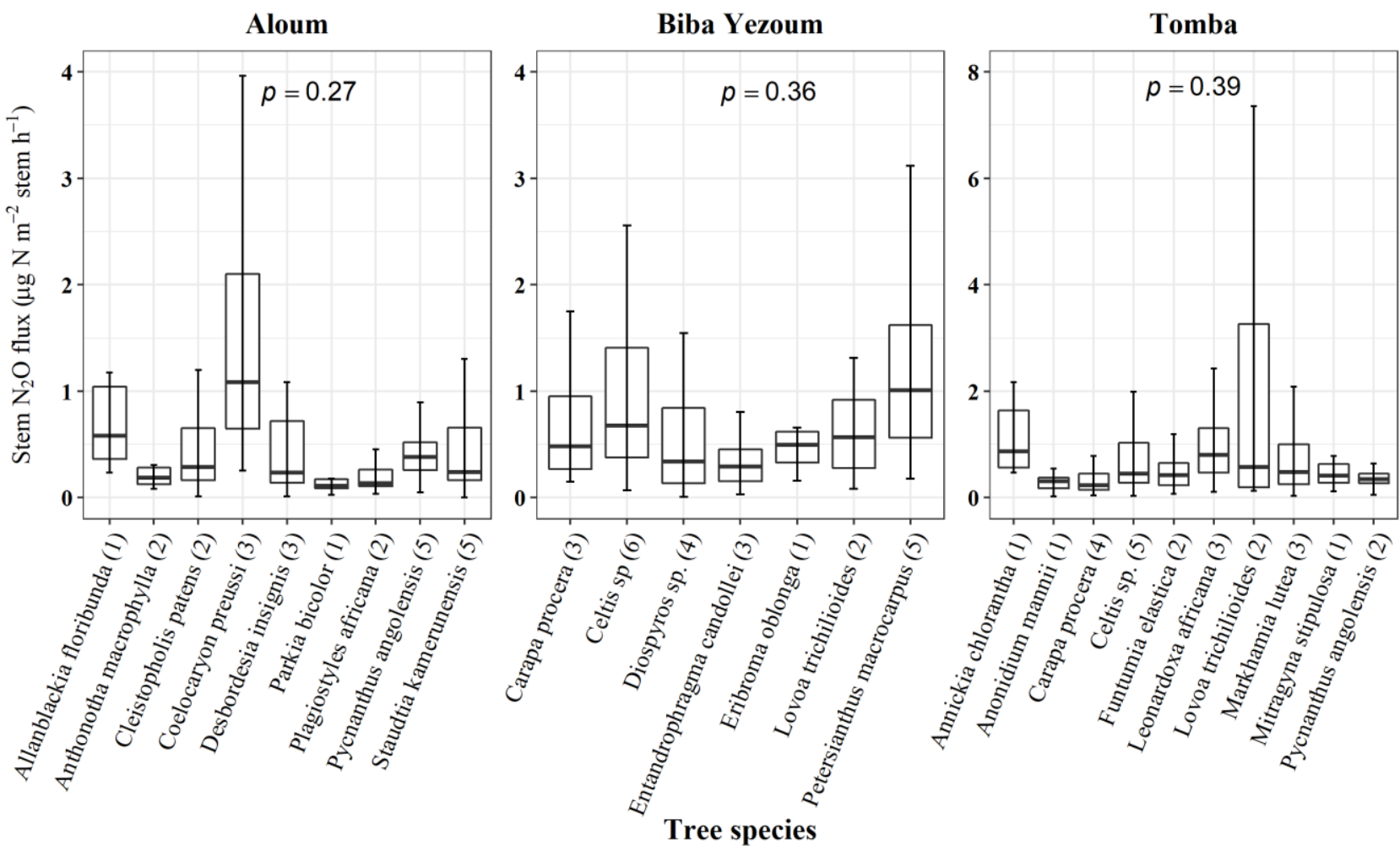

Figure 2.1. Stem $\mathrm{N}_{2} \mathrm{O}$ fluxes from 22 tree species at three forest sites (Aloum, Biba Yezoum and Tomba) across central and south Cameroon in the Congo Basin. Boxes $\left(25^{\text {th }}\right.$, median and $75^{\text {th }}$ percentile $)$ and whiskers $(1.5 \times$ interquartile range $)$ are based on $\mathrm{N}_{2} \mathrm{O}$ fluxes measured monthly from May 2017 to April 2018 for each tree species, and the values in parentheses represent the number of trees measured per species. There were no differences in $\mathrm{N}_{2} \mathrm{O}$ fluxes among species (linear mixed-effect models with Tukey’s HSD at $p>0.27$ ).

\subsubsection{Measurement of stem and soil $\mathrm{N}_{2} \mathrm{O}$ fluxes}

We measured in-situ stem $\mathrm{N}_{2} \mathrm{O}$ fluxes using stem chambers made from transparent polyethylene-terephthalate foil, as described by Wen et al. (2017). One month prior to measurement, we applied 1-cm wide silicone sealant strips (Otto Seal ${ }^{\circledR}$ S110, Hermann Otto $\mathrm{GmbH}$, Fridolfing, Germany) $20 \mathrm{~cm}$ apart around the surface of the tree stems (between 1.2-m and 1.4-m heights from the ground) that stayed permanently to ensure that all the stem chambers had air-tight seals. As many of the measured trees have buttresses (rendering stem chambers 
impossible to attach at low stem height, e.g. Fig. 2.2), we chose the measurements at an average of 1.3-m height (or between 1.2-1.4 m), congruent to the standard measurement of DBH. Since chamber installation is quick, chambers were newly installed on each sampling date, using the silicone sealant strips as a mark to ensure that the same 0.2-m length stem section was measured. We wrapped a piece of foil (cut approximately $50 \mathrm{~cm}$ longer than the measured stem circumference and fitted with a Luer-lock sampling port) around each stem. Using a gaspowered heat-gun, we "shrank" the top and bottom part of the foil to fit closely onto the silicone strips, leaving 0.2-m length between the top and bottom silicone strips, which served as the chamber for collecting gas samples (Fig. 2.2). We then wrapped strips of polyethylene foam around the edges of the foil and adjusted the foam tightly using lashing straps equipped with ratchet tensioners (two straps at the top and two at the bottom). The lashing straps adjusted the flexible foam and the foil (on top of the silicone strips) to any irregularities on the bark and ensured an airtight fitting.

After installation, we completely evacuated the air inside the stem chamber using a syringe fitted with a Luer-lock one-way check valve. Afterwards, we used a manual hand pump to refill the stem chamber with a known volume of ambient outside air for correct calculation of stem $\mathrm{N}_{2} \mathrm{O}$ flux. A 25-mL air sample was taken with syringe through the Luer-lock sampling port immediately after refilling the stem chamber with ambient air, and then again after 20, 40 and 60 minutes. Each air sample was immediately stored in pre-evacuated $12 \mathrm{~mL}$ Labco exetainers with rubber septa (Labco Limited, Lampeter, UK), maintaining an overpressure. 


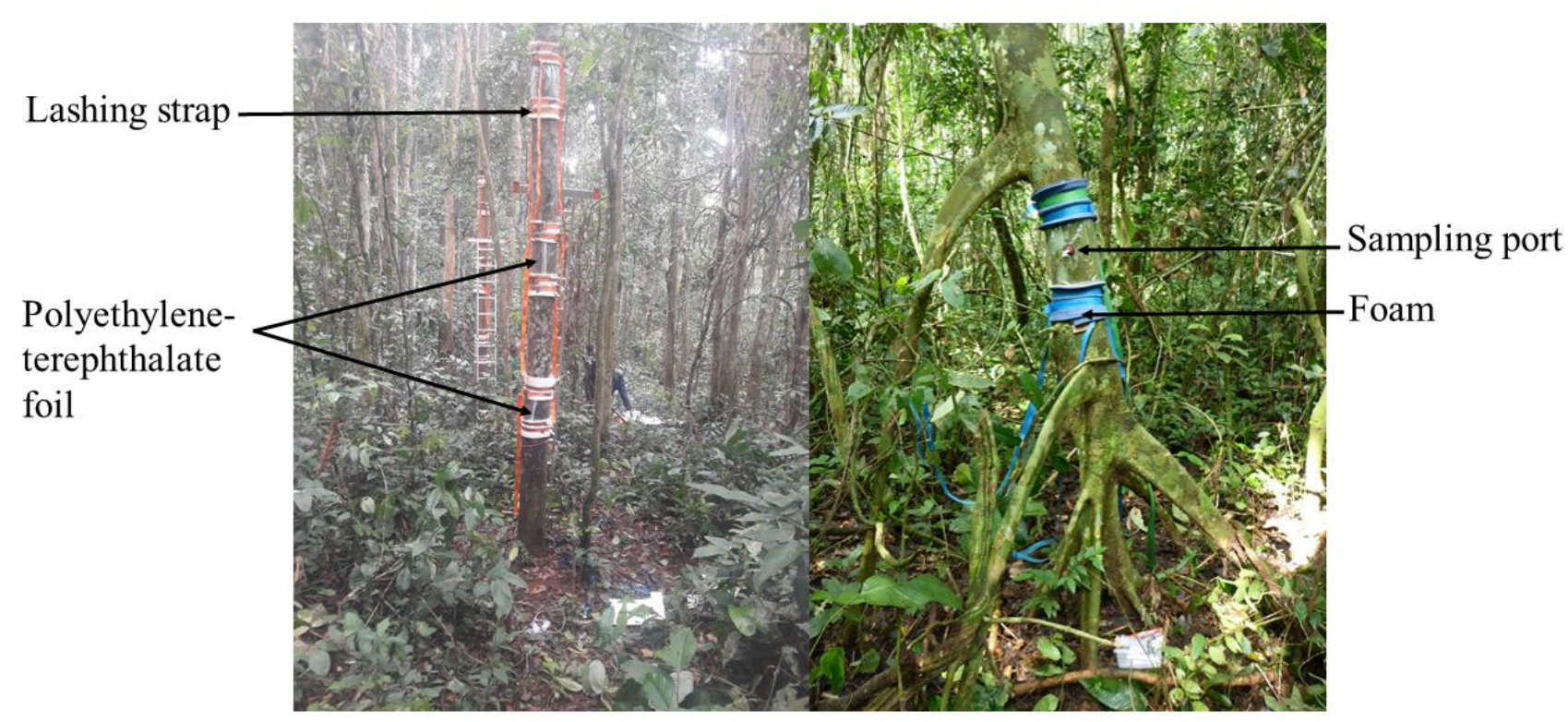

Figure 2.2. Sampling set-up for stem nitrous oxide $\left(\mathrm{N}_{2} \mathrm{O}\right)$-flux measurement at three stem heights in a rainforest in the Congo Basin, Cameroon.

In May 2018, we conducted a ${ }^{15} \mathrm{~N}$ tracing experiment at the Tomba site as a follow-on study to elucidate the source of stem $\mathrm{N}_{2} \mathrm{O}$ emissions. The tracing was conducted in three replicate plots per land use, where one tree was selected in each plot. Around each selected tree, $290 \mathrm{mg}{ }^{15} \mathrm{~N}$ (in the form of $\left({ }^{15} \mathrm{NH}_{4}\right)_{2} \mathrm{SO}_{4}$ with $98 \%{ }^{15} \mathrm{~N}$ ) dissolved in $8 \mathrm{~L}$ distilled water was applied evenly onto the soil surface of $0.8 \mathrm{~m}^{2}$ around the tree using a watering can (equivalent to $10 \mathrm{~mm}$ of rain). The water-filled pore space (WFPS) in the top 5-cm depth was $49 \pm 1 \%$ and $52 \pm 2 \%$ for the forest and CAF, respectively, which were similar to the monthly averages of these plots during this period (Fig. 2.4). Based on the monthly average soil mineral $\mathrm{N}$ concentrations in this site, the applied ${ }^{15} \mathrm{~N}$ was only $20 \%$ of the extant mineral $\mathrm{N}$ in the top 10 $\mathrm{cm}$ soil (resulting to a starting enrichment of $17 \%{ }^{15} \mathrm{~N}$ ), such that we only minimally changed the substrate which could influence $\mathrm{N}_{2} \mathrm{O}$ flux, similar to that described by Corre et al. (2014). Stem and soil ${ }^{15} \mathrm{~N}_{2} \mathrm{O}$ fluxes were measured one day, seven days and 14 days following ${ }^{15} \mathrm{~N}$ application, and on each sampling day gas samples were taken at 0,30 , and 60 minutes after 
chamber closure. The gas samples were stored in new pre-evacuated glass containers $(100 \mathrm{~mL})$ with rubber septa and transported to the University of Goettingen, Germany for analysis. We also stored ${ }^{15} \mathrm{~N}_{2} \mathrm{O}$ standards in similar $100-\mathrm{mL}$ glass containers, which were brought to Cameroon and back to Germany, to have the same storage duration as the gas samples in order to check for leakage; we found no difference in ${ }^{15} \mathrm{~N}_{2} \mathrm{O}$ with the original standard at our laboratory.

We measured soil $\mathrm{N}_{2} \mathrm{O}$ fluxes using vented, static chambers made from polyvinyl chloride that were permanently inserted $\sim 0.02 \mathrm{~m}$ into the soil at least one month prior to the start of measurements, as described in our earlier studies (e.g., Koehler et al., 2009b; Corre et al., 2014; Müller et al., 2015). On each sampling day, we covered the chamber bases with vented, static polyethylene hoods $\left(0.04 \mathrm{~m}^{2}\right.$ in area and $\sim 11 \mathrm{~L}$ total volume $)$ equipped with Luerlock sampling ports. Soil $\mathrm{N}_{2} \mathrm{O}$ fluxes were then determined by taking four gas samples $(25 \mathrm{~mL}$ each) at 2,12, 22 and 32 minutes after chamber closure. The samples were taken with a syringe and immediately injected into pre-evacuated $12 \mathrm{~mL}$ exetainers as described above.

Concurrent to the stem and soil $\mathrm{N}_{2} \mathrm{O}$-flux measurements, we sampled soil-air $\mathrm{N}_{2} \mathrm{O}$ concentrations at 50-cm depth from permanently installed stainless-steel probes (1-mm internal diameter) located at $\sim 1 \mathrm{~m}$ from the measured trees. The stainless steel probes were installed one month prior to the start of measurements. Luer-locks were attached to the probes, and on each sampling day the probes were first cleared of any previous accumulation of $\mathrm{N}_{2} \mathrm{O}$ concentration by removing $5-\mathrm{mL}$ air volume using a syringe and discarding it. We then took $25-\mathrm{mL}$ gas samples and stored them in pre-evacuated 12-mL exetainers as described above. 


\subsection{3. $\mathrm{N}_{2} \mathrm{O}$ analysis and flux rate calculation}

The $\mathrm{N}_{2} \mathrm{O}$ concentrations in the gas samples were analysed using a gas chromatograph equipped with an electron capture detector, a make-up gas of $5 \% \mathrm{CO}_{2}-95 \% \mathrm{~N}_{2}$ (SRI 8610C, SRI Instruments Europe $\mathrm{GmbH}$, Bad Honnef, Germany), and an autosampler (AS-210, SRI Instruments). ${ }^{15} \mathrm{~N}_{2} \mathrm{O}$ was analysed on an isotope ratio mass spectrometer (IRMS) (Finnigan Deltaplus XP, Thermo Electron Corporation, Bremen, Germany). We calculated $\mathrm{N}_{2} \mathrm{O}$ fluxes from the linear change in concentrations over time of chamber closure, and adjusted the fluxes with air temperature and atmospheric pressure, measured at each replicate plot on each sampling day. We included zero and negative fluxes in our data analysis.

We up-scaled the measured stem $\mathrm{N}_{2} \mathrm{O}$ fluxes (considering trees $\geq 10 \mathrm{~cm} \mathrm{DBH}$ ) to annual values on a ground area in the following steps: (1) the relationship between stem $\mathrm{N}_{2} \mathrm{O}$ fluxes and stem heights was modelled from the 16 individual trees per land use (see above) that were measured at multiple heights, from which we observed decreases in stem $\mathrm{N}_{2} \mathrm{O}$ fluxes with increasing stem heights. A linear function was statistically the best fit characterizing these decreases in stem $\mathrm{N}_{2} \mathrm{O}$ fluxes with height. (2) Using this linear function and considering the stem surface area as a frustum with $20-\mathrm{cm}$ increment, the tree-level $\mathrm{N}_{2} \mathrm{O}$ fluxes on each sampling day was calculated for the regularly measured six trees per plot. (3) The annual treelevel $\mathrm{N}_{2} \mathrm{O}$ fluxes from these regularly measured six trees per plot were calculated using a trapezoidal interpolation between the tree-level $\mathrm{N}_{2} \mathrm{O}$ fluxes (step 2) and measurement day intervals from May 2017 to April 2018. (4) The annual tree-level $\mathrm{N}_{2} \mathrm{O}$ fluxes were then extrapolated on a ground-area basis for each replicate plot as follows:

Annual stem $\mathrm{N}_{2} \mathrm{O}$ flux $\left(\mathrm{kg} \mathrm{N}_{2} \mathrm{O}-\mathrm{N} \mathrm{ha}^{-1} \mathrm{yr}^{-1}\right)=\left\{\Sigma\left[\left(\left(\mathrm{X}_{1-24} \div \mathrm{DBH}_{1-24}\right) / 24\right) * \mathrm{DBH}_{\mathrm{n}}\right]\right\} \div \mathrm{A}$ where: $\mathrm{X}_{1-24}$ and $\mathrm{DBH}_{1-24}$ are the corresponding annual tree-level $\mathrm{N}_{2} \mathrm{O}$ flux $\left(\mathrm{kg} \mathrm{N}_{2} \mathrm{O}-\mathrm{N}\right.$ yr ${ }^{-1}$ of each tree; step 3) and DBH (cm) of each of the 24 measured trees (6 trees $\mathrm{x} 4$ plots) per land 
use at each site; $\mathrm{DBH}_{\mathrm{n}}$ is the individual tree $\mathrm{DBH}(\mathrm{cm})$ measured for all trees (with $\geq 10 \mathrm{~cm}$ DBH) present within the inner 40-m x 40-m area of each plot (Table S2.1); $\Sigma$ is the sum of the annual $\mathrm{N}_{2} \mathrm{O}$ fluxes of all trees within each plot $\left(\mathrm{kg} \mathrm{N}_{2} \mathrm{O}-\mathrm{N} \mathrm{yr}^{-1}\right)$; $\mathrm{A}$ is the plot area $(0.16 \mathrm{ha})$. For step 4 of the CAF plots, the annual stem $\mathrm{N}_{2} \mathrm{O}$ flux was the sum of the cacao and shade trees (Table S2.1); as these shade trees were remnants of the original forest, we used the average annual tree-level $\mathrm{N}_{2} \mathrm{O}$ flux of the measured trees in the corresponding paired forest plots multiplied by the actual DBH of the shade trees in the CAF plots. This spatial extrapolation based on trees' DBH of each plot was also supported by the fact that there were no significant differences in stem $\mathrm{N}_{2} \mathrm{O}$ fluxes among tree species (Fig. 2.1).

Annual soil $\mathrm{N}_{2} \mathrm{O}$ fluxes from each plot were calculated using the trapezoidal rule to interpolate the measured fluxes from May 2017 to Apr. 2018, as employed in our earlier studies (e.g., Koehler et al., 2009b; Veldkamp et al., 2013). Finally, the annual $\mathrm{N}_{2} \mathrm{O}$ fluxes from each replicate plot were represented by the sum of the stem and soil $\mathrm{N}_{2} \mathrm{O}$ fluxes.

\subsubsection{Soil and meteorological variables}

We measured soil temperature, WFPS, and extractable mineral $\mathrm{N}$ in the top 5-cm depth concurrent to stem and soil $\mathrm{N}_{2} \mathrm{O}$ flux measurements on each sampling day. The soil temperature was measured $\sim 1 \mathrm{~m}$ away from the soil chambers using a digital thermometer (GTH 175, Greisinger Electronic GmbH, Regenstauf, Germany). We determined soil WFPS and extractable mineral $\mathrm{N}$ by pooling soil samples from four sampling locations within $1 \mathrm{~m}$ from each soil chamber in each replicate plot. Gravimetric moisture content was determined by ovendrying the soils at $105^{\circ} \mathrm{C}$ for $24 \mathrm{~h}$ and WFPS was calculated using a particle density of $2.65 \mathrm{~g}$ $\mathrm{cm}^{-3}$ for mineral soil and our measured soil bulk density (Table 2.1). Soil mineral $\mathrm{N}_{\left(\mathrm{NO}_{3}{ }^{-} \text {and }\right.}$ $\mathrm{NH}_{4}{ }^{+}$) was extracted in the field by putting a subsample of soil into a pre-weighed bottle containing $150 \mathrm{~mL} 0.5 \mathrm{M} \mathrm{K}_{2} \mathrm{SO}_{4}$. The bottles were weighed and then shaken for 1 hour, and 
the solution was filtered through pre-washed (with $0.5 \mathrm{M} \mathrm{K}_{2} \mathrm{SO}_{4}$ ) filter papers. The extracts were immediately frozen and later transported to the University of Goettingen, where $\mathrm{NH}_{4}^{+}$and $\mathrm{NO}_{3}{ }^{-}$concentrations were analysed using continuous flow injection colorimetry (SEAL Analytical AA3, SEAL Analytical GmbH, Norderstedt, Germany) (described in details by Hassler et al., 2015). The dry mass of soil extracted for mineral $\mathrm{N}$ was calculated using the measured gravimetric moisture content.

During each measurement day, we set up a portable weather station in each site to record relative humidity, air temperature and solar irradiance over the course of each sampling day at 15-minute interval. We calculated VPD as the difference between saturation vapour pressure (based on its established equation with air temperature) and actual vapour pressure (using saturation vapour pressure and relative humidity; Allen, Pereira, Raes, \& Smith, 1998).

Soil biochemical characteristics were measured in April 2017 at all 24 plots. We collected soil samples from the top 50-cm depth, where changes in soil biochemical characteristics resulting from land-use changes have been shown to occur (van Straaten et al., 2015; Tchiofo Lontsi et al., 2019). In each plot, we collected ten soil samples from the top 0$10 \mathrm{~cm}$, and five soil samples each from 10-30 and 30-50 cm depths; in total, we collected 480 soil samples from the 24 plots. The soil samples were air-dried, 2-mm sieved and transported to the University of Goettingen, where they were dried again at $40{ }^{\circ} \mathrm{C}$ before analysis. Soil $\mathrm{pH}$ was analysed from 1:4 soil-to-distilled water ratio. Soil texture for each plot was determined using the pipette method after iron oxide and organic matter removal (Kroetsch \& Wang, 2008). Effective cation exchange capacity (ECEC) and exchangeable cation concentrations (Ca, $\mathrm{Mg}$, $\mathrm{K}, \mathrm{Na}, \mathrm{Al}, \mathrm{Fe}, \mathrm{Mn}$ ) were determined by percolating the soil samples with unbuffered $1 \mathrm{M} \mathrm{NH}_{4} \mathrm{Cl}$ , and the extracts analysed using inductively coupled plasma-atomic emission spectrometer (ICP-AES; iCAP 6300 Duo VIEW ICP Spectrometer, Thermo Fischer Scientific GmbH, 
Dreieich, Germany). Soil subsamples were ground and analysed for total organic C and $\mathrm{N}$ using a CN analyser (vario EL cube; Elementar Analysis Systems GmbH, Hanau, Germany), and the soil ${ }^{15} \mathrm{~N}$ natural abundance signatures were determined using IRMS (Delta Plus; Finnigan MAT, Bremen, Germany). Soil organic carbon (SOC) and total N stocks were calculated for the top $50 \mathrm{~cm}$ in both land uses. We used the bulk density of the reference forest for calculating the SOC and total $\mathrm{N}$ stocks of the converted CAF in order to avoid overestimations of element stocks resulting from increases in soil bulk densities following land-use conversion (Veldkamp, 1994; van Straaten et al., 2015).

To evaluate the representativeness of our study area with the rest of the Congo Basin forest, we estimated the proportion of the Congo rainforest area which have similar biophysical conditions (elevation, precipitation ranges and soil type) as our study sites (Table S2.1). Using the FAO's Global Ecological Zone map for the humid tropics, we identified the areal coverage of (i) Ferralsols (FAO Harmonized World Soil Database; FAO/IIASA/ISRIC/ISS-CAS/JRC, 2012) with (ii) elevation $\leq 1000 \mathrm{~m}$ asl (SRTM digital elevation model; Jarvis et al., 2008) and (iii) precipitation range between 1,500 and 2,100 $\mathrm{mm} \mathrm{yr}^{-1}$ (WorldClim dataset; Hijmans et al., 2005) within the six Congo rainforest countries (Fig. 2.3). This analysis was conducted using QGIS version 3.6.3. 


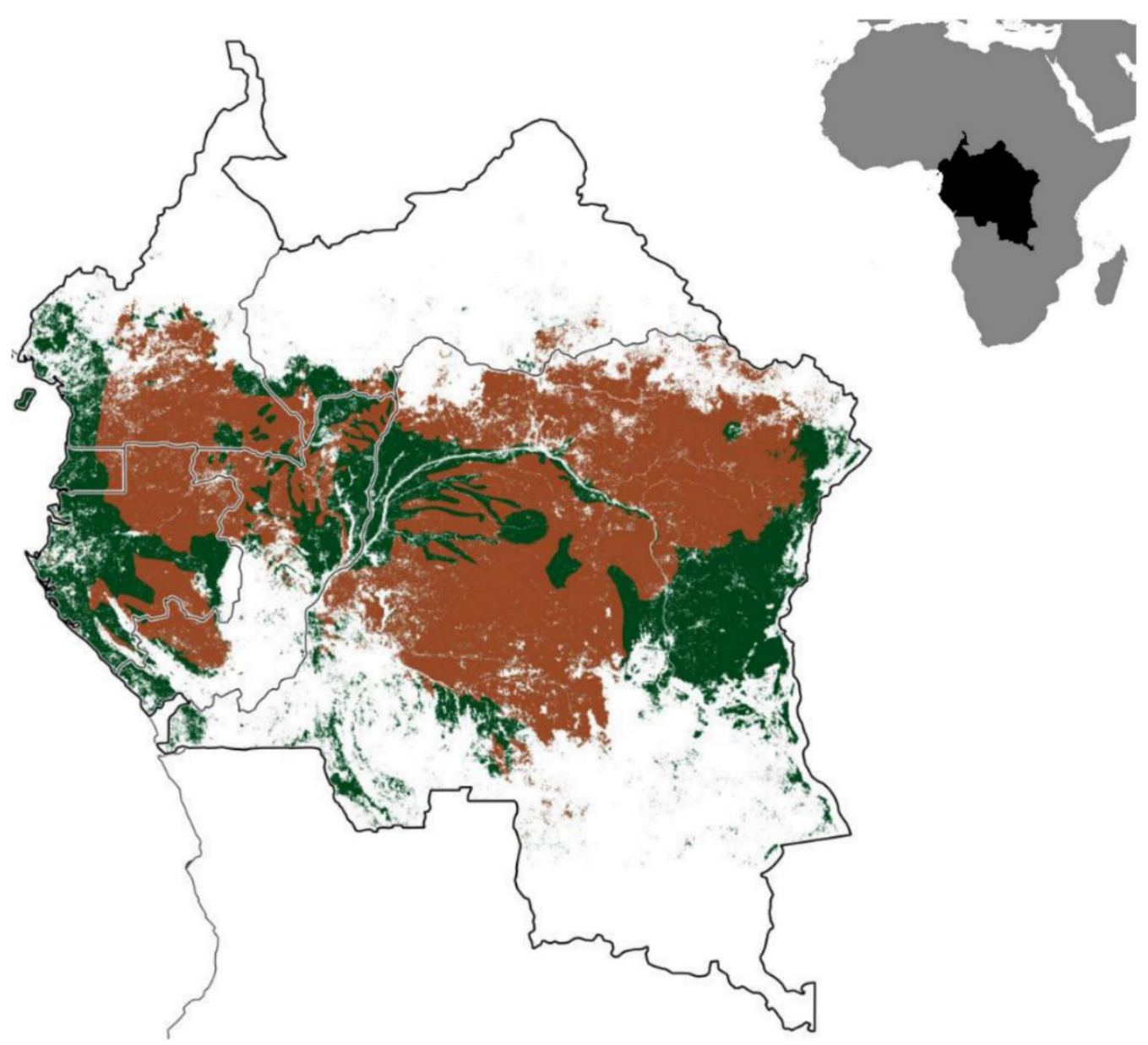

Figure 2.3. Map of the Congo Basin rainforest (green) spanning across the six major Congo Basin countries. Brown shaded area represents the proportion of the Congo rainforest with similar biophysical conditions as our study sites (Ferralsol soils, $\leq 1000$ m elevation, and 1500$2100 \mathrm{~mm} \mathrm{yr}^{-1}$ precipitation).

\subsubsection{Statistical analyses}

Statistical comparisons between land uses or among sites for stem and soil $\mathrm{N}_{2} \mathrm{O}$ fluxes were performed on the monthly measurements and not on the annual values as the latter are trapezoidal interpolations. As the six trees and four chambers per plot were considered subsamples representing each replicate plot, we conducted the statistical analysis using the means of the six trees and of the four chambers on each sampling day for each replicate plot 
(congruent to our previous studies, e.g. Koehler et al., 2009b; Veldkamp et al., 2013; Matson et al., 2017). We tested each parameter for normal distribution (Shapiro-Wilk's test) and homogeneity of variance (Levene's test), and applied a logarithmic or square root transformation when these assumptions were not met. For the repeatedly measured parameters, i.e. stem and soil $\mathrm{N}_{2} \mathrm{O}$ fluxes and the accompanying soil variables (temperature, WFPS, $\mathrm{NH}_{4}{ }^{+}$ and $\mathrm{NO}_{3}{ }^{-}$concentrations), differences between land-use types for each site or differences among sites for each land-use type were tested using linear mixed effect (LME) models with land use or site as fixed effect and replicate plots and sampling days as random effects. We extended the LME model to include either (1) a variance function that allows different variances of the fixed effect, and/or (2) a first-order temporal autoregressive process, which assumes that correlation between sampling days decreases with increasing time difference, if this improved the relative goodness of the model fit based on the Akaike information criterion (Crawley, 2009). Using diagnostic plots, the model residuals were checked for normality and homoscedasticity, and the data were log- or square root-transformed when necessary. We assessed significant differences between land uses or sites using analysis of variance (ANOVA) with Fisher's least significant difference (LSD) test.

We also analysed if there were differences in stem $\mathrm{N}_{2} \mathrm{O}$ fluxes among tree species across four forest plots at each site as well as across the three sites. Similar LME analysis was carried out with tree species as fixed effect, and the random effects were trees belonging to each species and sampling days; only for this test, we used individual trees as random effect because most of the tree species (selected based on their IVI; see section 2.1) were not present in all plots, which is typical in species-diverse tropical forest. For soil biochemical characteristics that were measured once (Table 2.1), one-way ANOVA with Fisher's LSD test was used to assess the differences between land uses or sites for the variables with normal distribution and 
homogenous variance; if otherwise, we applied Kruskal-Wallis ANOVA with multiple comparison extension test.

To determine the temporal controls of soil and meteorological variables (temperature, WFPS, $\mathrm{NH}_{4}{ }^{+}$and $\mathrm{NO}_{3}{ }^{-}$concentrations, soil-air $\mathrm{N}_{2} \mathrm{O}$ concentration, VPD) on stem and soil $\mathrm{N}_{2} \mathrm{O}$ fluxes, we conducted Spearman's Rank correlation tests using the means of the four replicate plots for each land use on each sampling day. For each land use, the correlation tests were conducted across sites and sampling days ( $n=33$, from 3 sites $\times 11$ monthly measurements).

To determine the spatial controls of soil biochemical characteristics (which were measured once, Table 2.1) on stem and soil $\mathrm{N}_{2} \mathrm{O}$ fluxes, we used the plots' annual $\mathrm{N}_{2} \mathrm{O}$ emissions and tested with Spearman's Rank correlation across land uses and sites $(n=24$, from 3 sites $\times 2$ land uses $\times 4$ replicate plots). The statistical significance for all the tests were set at $p \leq 0.05$. All statistical analyses were conducted using the open source software R 3.5.2 (R Core Team, 2018).

\subsection{Results}

\subsubsection{Stem $\mathrm{N}_{2} \mathrm{O}$ emissions}

Stem $\mathrm{N}_{2} \mathrm{O}$ emissions neither differed between forest and CAF at each site $(p=0.15-0.76$; Table 2.2) nor among the three sites for each land use ( $p=0.16-0.78$; Table 2.2). There were also no differences in stem $\mathrm{N}_{2} \mathrm{O}$ emissions among tree species in forest plots at each site as well as across the three sites ( $p=0.06-0.39$; Fig. 2.1). For the forests, stem $\mathrm{N}_{2} \mathrm{O}$ emissions exhibited seasonal pattern with larger fluxes in the wet season than in the dry season at all sites (all $p<$ 0.01; Fig. 2.4, Table S2.2). However, for the CAF, we observed seasonal differences only at Aloum site $\left(p<0.01\right.$; Fig. 2.4, Table S2.3). Contributions of annual stem $\mathrm{N}_{2} \mathrm{O}$ emissions reached up to one-third of the total (soil + stem) $\mathrm{N}_{2} \mathrm{O}$ emissions from the forests (Table 2.2). 
Table 2.2. Mean $( \pm \mathrm{SE}, n=4)$ stem and soil $\mathrm{N}_{2} \mathrm{O}$ emission as well as annual stem, soil, and total (soil + stem) $\mathrm{N}_{2} \mathrm{O}$ fluxes from forest and cacao agroforestry (CAF) within each site in the Congo Basin, Cameroon. Means followed by different lowercase letters indicate significant differences between land-use types within each site and different capital letters indicate significant differences among the three sites within a land-use type (linear mixed-effect models with Tukey's HSD at $p \leq 0.05$ ).

\begin{tabular}{|c|c|c|c|c|c|c|}
\hline $\begin{array}{l}\text { Site/ } \\
\text { Land-use type }\end{array}$ & $\begin{array}{l}\text { Stem } \mathrm{N}_{2} \mathrm{O} \text { fluxes } \\
\left(\mu \mathrm{g} \mathrm{m}^{-2} \text { stem }^{-1}\right)\end{array}$ & $\begin{array}{l}\text { Annual stem } \\
\mathrm{N}_{2} \mathrm{O} \text { fluxes } \\
\left(\mathrm{kg} \mathrm{N} \mathrm{ha}^{-1} \mathrm{yr}^{-1}\right) \\
\end{array}$ & 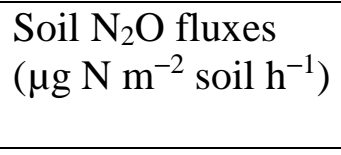 & $\begin{array}{l}\text { Annual soil } \\
\mathrm{N}_{2} \mathrm{O} \text { fluxes } \\
\left(\mathrm{kg} \mathrm{N} \mathrm{ha}^{-1} \mathrm{yr}^{-1}\right) \\
\end{array}$ & $\begin{array}{l}\text { Total (soil + } \\
\text { stem) } \mathrm{N}_{2} \mathrm{O} \text { flux } \\
\left(\mathrm{kg} \mathrm{N} \mathrm{ha}^{-1} \mathrm{yr}^{-1}\right)\end{array}$ & $\begin{array}{l}\text { Contribution of } \\
\text { stem to total } \mathrm{N}_{2} \mathrm{O} \\
\text { flux }(\%)\end{array}$ \\
\hline \multicolumn{7}{|l|}{ Aloum } \\
\hline Forest & $1.13 \pm 0.22^{\mathrm{a}, \mathrm{A}}$ & $0.13 \pm 0.00$ & $13.7 \pm 2.2^{\mathrm{a}, \mathrm{A}}$ & $0.87 \pm 0.14$ & $1.00 \pm 0.14$ & $13.7 \pm 1.8$ \\
\hline \multirow[t]{2}{*}{ CAF } & $0.90 \pm 0.16^{\mathrm{a}, \mathrm{A}}$ & $0.09 \pm 0.01$ & $15.2 \pm 2.8^{\mathrm{a}, \mathrm{A}}$ & $1.06 \pm 0.17$ & $1.15 \pm 0.17$ & $7.8 \pm 1.6$ \\
\hline & & $(0.02 \pm 0.01)$ & & & & \\
\hline \multicolumn{7}{|l|}{ Biba Yezoum } \\
\hline Forest & $2.38 \pm 0.48^{\mathrm{a}, \mathrm{A}}$ & $0.87 \pm 0.05$ & $17.2 \pm 2.9^{\mathrm{a}, \mathrm{A}}$ & $1.46 \pm 0.23$ & $2.33 \pm 0.24$ & $38.2 \pm 3.5$ \\
\hline \multirow[t]{2}{*}{ CAF } & $1.11 \pm 0.21^{\mathrm{a}, \mathrm{A}}$ & $0.12 \pm 0.01$ & $10.6 \pm 2.1^{\mathrm{a}, \mathrm{A}}$ & $0.80 \pm 0.20$ & $0.92 \pm 0.20$ & $14.8 \pm 3.0$ \\
\hline & & $(0.03 \pm 0.01)$ & & & & \\
\hline \multicolumn{7}{|l|}{ Tomba } \\
\hline Forest & $0.89 \pm 0.10^{\mathrm{a}, \mathrm{A}}$ & $0.14 \pm 0.01$ & $15.0 \pm 1.7^{\mathrm{a}, \mathrm{A}}$ & $1.18 \pm 0.18$ & $1.31 \pm 0.18$ & $11.4 \pm 2.2$ \\
\hline \multirow[t]{2}{*}{ CAF } & $0.90 \pm 0.12^{\mathrm{a}, \mathrm{A}}$ & $0.12 \pm 0.00$ & $15.8 \pm 2.0^{\mathrm{a}, \mathrm{A}}$ & $1.25 \pm 0.14$ & $1.37 \pm 0.14$ & $8.9 \pm 0.9$ \\
\hline & & $(0.05 \pm 0.02)$ & & & & \\
\hline
\end{tabular}

Note. Annual stem and soil $\mathrm{N}_{2} \mathrm{O}$ fluxes were not statistically tested for differences among sites or between land-use types since these annual values are trapezoidal extrapolations (see section 2.3.3, pg. 32). Annual stem $\mathrm{N}_{2} \mathrm{O}$ emissions in parentheses are from cacao trees only. 

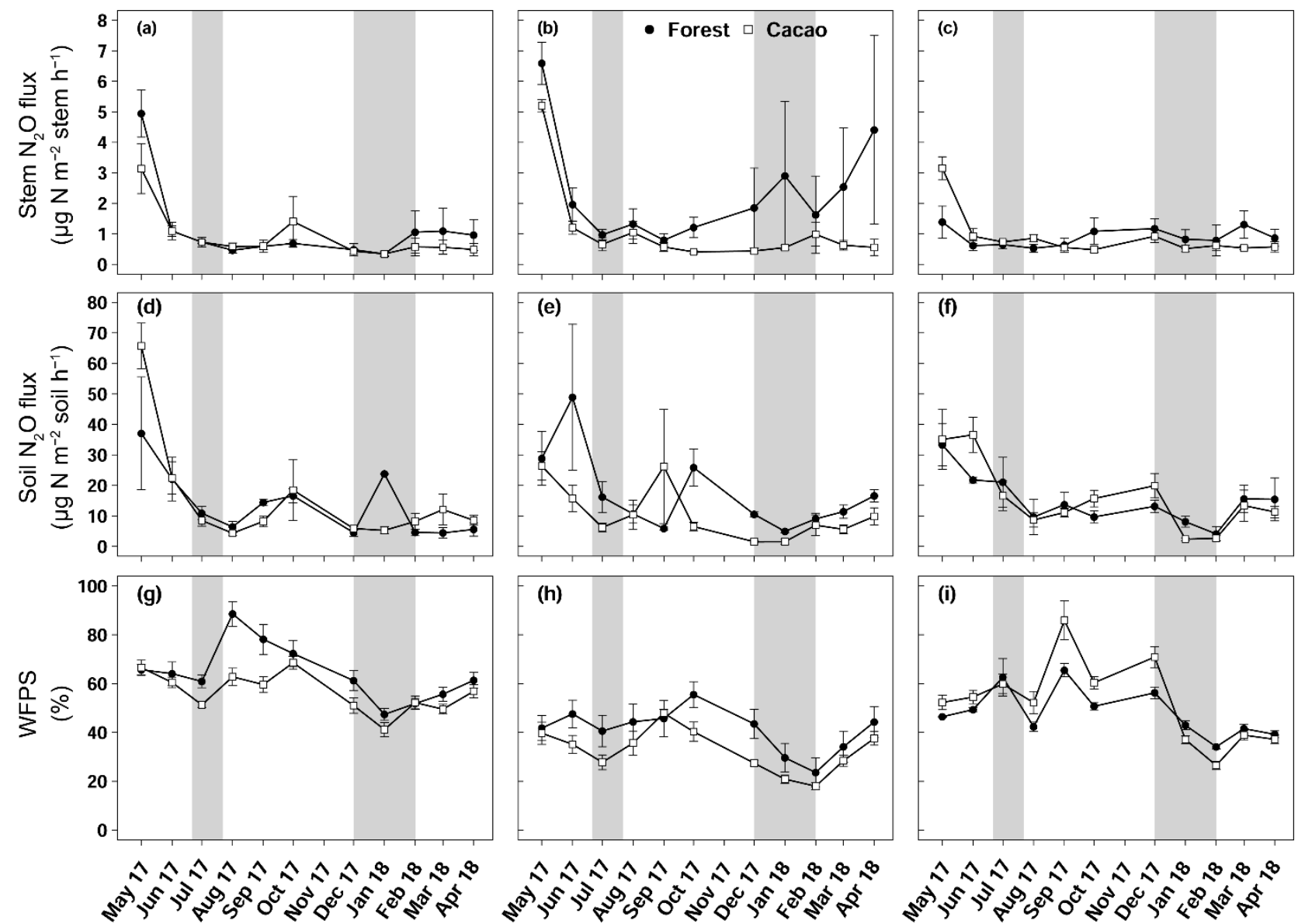

Figure 2.4. Mean $( \pm \mathrm{SE}, n=4)$ stem $\mathrm{N}_{2} \mathrm{O}$ fluxes (top panel), soil $\mathrm{N}_{2} \mathrm{O}$ fluxes (middle panel) and water-filled pore space (bottom panel) in Aloum site (a, d and g), Biba Yezoum site (b, e and h) and Tomba site (c, f and i) in the Congo Basin, Cameroon, measured monthly from May 2017 to April 2018; grey shadings mark the dry season.

From the ${ }^{15} \mathrm{~N}$-tracing experiment, stem ${ }^{15} \mathrm{~N}-\mathrm{N}_{2} \mathrm{O}$ emissions mirrored soil ${ }^{15} \mathrm{~N}_{-} \mathrm{N}_{2} \mathrm{O}$ emissions from both land uses (Fig.2.5). One day after ${ }^{15} \mathrm{~N}$ addition to the soil, substantial ${ }^{15} \mathrm{~N}$ $\mathrm{N}_{2} \mathrm{O}$ were emitted from the stem as well as from the soil. This diminished within two weeks as the added ${ }^{15} \mathrm{~N}$ recycled within the soil- $\mathrm{N}$-cycling processes, diluting the ${ }^{15} \mathrm{~N}$ signatures; nevertheless, the ${ }^{15} \mathrm{~N}$ signatures of stem- and soil-emitted $\mathrm{N}_{2} \mathrm{O}$ remained elevated above the natural abundance level (Fig. 2.5). 


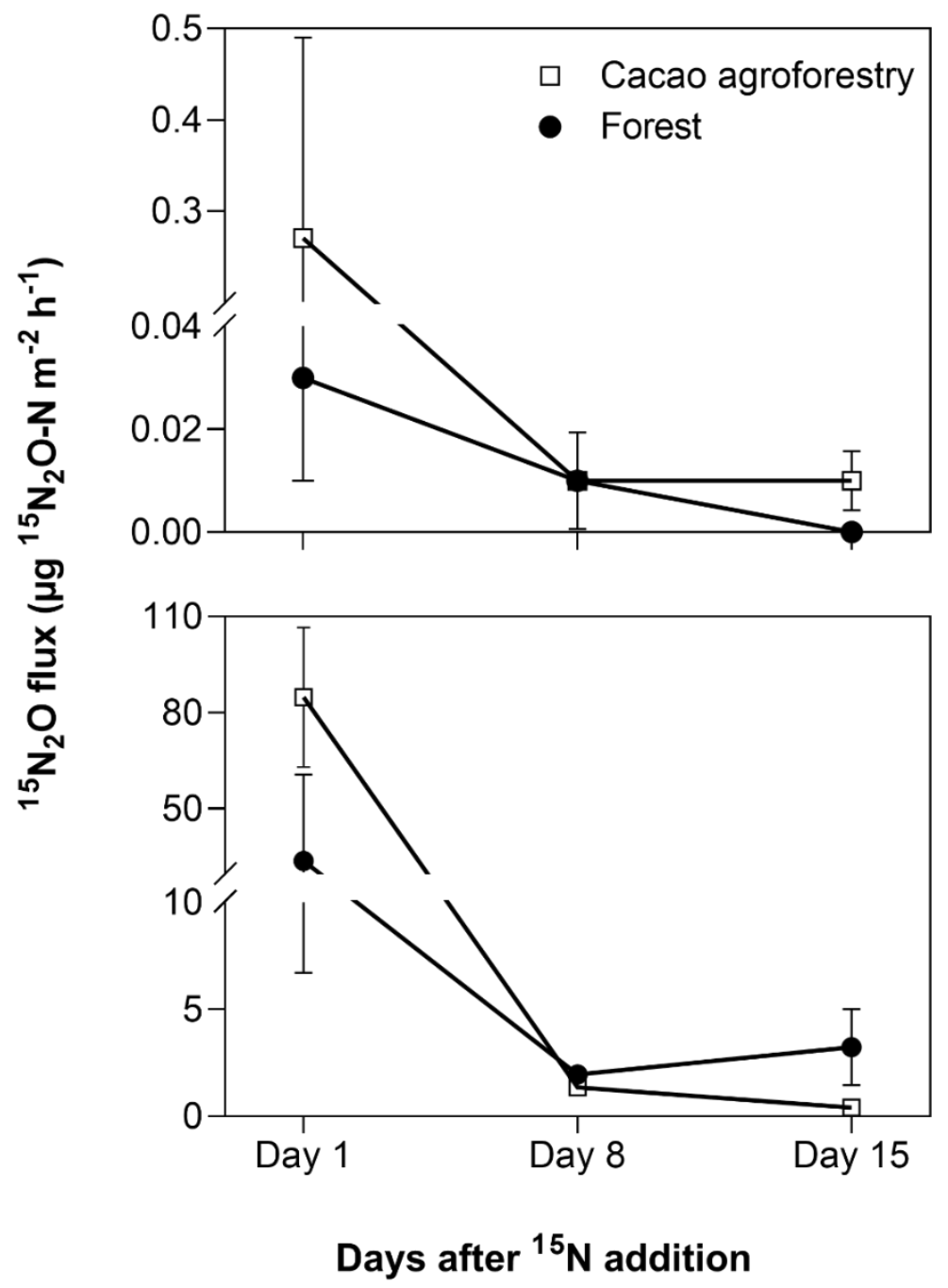

Figure 2.5. Mean $( \pm \mathrm{SE}, n=3){ }^{15} \mathrm{~N}_{2} \mathrm{O}$ fluxes from stems (top panel, unit is per $\mathrm{m}^{2}$ stem area) and soil (bottom panel, unit is per $\mathrm{m}^{2}$ ground area) in the Congo Basin, Cameroon. In May 2018, $290 \mathrm{mg}{ }^{15} \mathrm{~N}$ (in the form of $\left({ }^{15} \mathrm{NH}_{4}\right)_{2} \mathrm{SO}_{4}$ with $98 \%{ }^{15} \mathrm{~N}$ ) was dissolved in $8 \mathrm{~L}$ distilled water and sprayed within $0.8-\mathrm{m}^{2}$ area around each tree (equal to $10 \mathrm{~mm}$ rain), which was only $20 \%$ of the extant mineral $\mathrm{N}$ in the top $10 \mathrm{~cm}$ soil and $49 \pm 1 \%$ and $52 \pm 2 \%$ water-filled pore space for the forest and CAF, respectively, comparable to the soil water content of the site (Fig. 2.4).

Across the study period, stem $\mathrm{N}_{2} \mathrm{O}$ emissions from the forests were positively correlated with air temperature, soil-air $\mathrm{N}_{2} \mathrm{O}$ concentrations and VPD (Table 2.3) and negatively correlated with WFPS and $\mathrm{NH}_{4}{ }^{+}$contents (Table 2.3). The negative correlation of stem $\mathrm{N}_{2} \mathrm{O}$ emissions 
with WFPS was possibly spurious, as this correlation may have been driven by the autocorrelation between WFPS and air temperature $(R=-0.59, p<0.01, n=33)$. In CAF, stem $\mathrm{N}_{2} \mathrm{O}$ emissions were only positively correlated with soil $\mathrm{N}_{2} \mathrm{O}$ emissions (Table 2.3).

Table 2.3. Spearman correlation coefficients of stem $\mathrm{N}_{2} \mathrm{O}$ flux $\left(\mu \mathrm{g} \mathrm{N} \mathrm{m}{ }^{-2}\right.$ stem h$\left.^{-1}\right)$ and soil $\mathrm{N}_{2} \mathrm{O}$ flux $\left(\mu \mathrm{g} \mathrm{N} \mathrm{m}{ }^{-2}\right.$ soil $\left.\mathrm{h}^{-1}\right)$ with air temperature $\left({ }^{\circ} \mathrm{C}\right)$, water-filled pore space (WFPS) $(\%$, top 5-cm depth), extractable $\mathrm{NH}_{4}{ }^{+}$(mg N kg${ }^{-1}$, top 5-cm depth), soil-air $\mathrm{N}_{2} \mathrm{O}$ concentration (ppm $\mathrm{N}_{2} \mathrm{O}$ at 50-cm depth), and vapour pressure deficit (VPD) (kPa), using the monthly means of the four replicate plots per land use across the three sites from May 2017 to April $2018(n=33)$.

\begin{tabular}{llllllll}
\hline $\begin{array}{l}\text { Land } \\
\text { use }\end{array}$ & Variable & $\begin{array}{l}\text { Soil } \mathrm{N}_{2} \mathrm{O} \\
\text { flux }\end{array}$ & $\begin{array}{l}\text { Air } \\
\text { temp. }\end{array}$ & WFPS & $\mathrm{NH}_{4}^{+}$ & $\begin{array}{l}\text { Soil-air } \mathrm{N}_{2} \mathrm{O} \\
\text { concentration }\end{array}$ & VPD \\
\hline Forest & Stem $\mathrm{N}_{2} \mathrm{O}$ flux & 0.25 & $0.39^{\mathrm{a}}$ & $-0.41^{\mathrm{a}}$ & $-0.57^{\mathrm{b}}$ & $0.41^{\mathrm{a}}$ & $0.62^{\mathrm{b}}$ \\
& Soil $\mathrm{N}_{2} \mathrm{O}$ flux & & 0.07 & 0.15 & $-0.43^{\mathrm{a}}$ & $0.55^{\mathrm{b}}$ & -0.01 \\
\hline CAF & Stem $\mathrm{N}_{2} \mathrm{O}$ flux & $0.60^{\mathrm{b}}$ & -0.29 & 0.17 & -0.26 & 0.21 & 0.21 \\
& & & & & & & 0.10 \\
& Soil $\mathrm{N}_{2} \mathrm{O}$ flux & & $-0.34^{\mathrm{a}}$ & $0.53^{\mathrm{b}}$ & -0.14 & $0.51^{\mathrm{b}}$ & 0.10 \\
\hline${ }_{\mathrm{b}} p \leq 0.05,{ }^{\mathrm{a}} p \leq 0.01$. & & & & & &
\end{tabular}

We detected no difference in WFPS between the forest and CAF ( $p=0.15-0.28$; Table 2.4) at any of the sites. For the CAF, we detected higher WFPS in the wet season compared to the dry season at two sites ( $p<0.01$; Fig. 2.4, Table S2.3) whereas there was no seasonal difference in WFPS for the forests at any sites $(p=0.31-0.92$; Fig. 2.4, Table S2.2). At all the three sites, the dominant form of mineral $\mathrm{N}$ was $\mathrm{NH}_{4}{ }^{+}$(Table 2.4). There was generally no difference in soil $\mathrm{NH}_{4}{ }^{+}$and $\mathrm{NO}_{3}{ }^{-}$between the wet and dry seasons $(p=0.12-0.93)$, except for the forests at two sites with larger values in the dry than wet season $(p<0.01$; Tables S2 and S3). 
Table 2.4. Mean ( \pm SE, $n=4)$ water-filled pore space (WFPS) and extractable mineral $N$ in the top $5 \mathrm{~cm}$ of soil in forest and cacao agroforestry (CAF) within each site in Congo Basin, Cameroon, measured monthly from May 2017 to April 2018. Means followed by different lowercase letters indicate significant differences between land-use types within each site and different capital letters indicate significant differences among the three sites within a land-use type (linear mixed-effect models with Tukey's HSD at $p \leq 0.05$ ).

\begin{tabular}{llll}
\hline $\begin{array}{l}\text { Site/ Land-use } \\
\text { type }\end{array}$ & WFPS $(\%)$ & $\begin{array}{l}\mathrm{NH}_{4}^{+} \\
\left(\mathrm{mg} \mathrm{N} \mathrm{kg}^{-1}\right)\end{array}$ & $\begin{array}{l}\mathrm{NO}_{3}^{-} \\
\left(\mathrm{mg} \mathrm{N} \mathrm{kg}^{-1}\right)\end{array}$ \\
\hline Aloum & $64.3 \pm 3.6^{\mathrm{a}, \mathrm{A}}$ & $7.3 \pm 1.0^{\mathrm{a}, \mathrm{A}}$ & $6.3 \pm 1.2^{\mathrm{a}, \mathrm{A}}$ \\
\hline Forest & $56.4 \pm 2.5^{\mathrm{a}, \mathrm{A}}$ & $5.1 \pm 0.8^{\mathrm{a}, \mathrm{B}}$ & $2.4 \pm 0.6^{\mathrm{b}, \mathrm{A}}$ \\
CAF & & & \\
\hline Biba Yezoum & $41.5 \pm 2.7^{\mathrm{a}, \mathrm{B}}$ & $4.9 \pm 0.4^{\mathrm{b}, \mathrm{B}}$ & $2.9 \pm 0.5^{\mathrm{a}, \mathrm{B}}$ \\
\hline Forest & $32.6 \pm 2.7^{\mathrm{a}, \mathrm{B}}$ & $7.3 \pm 0.4^{\mathrm{a}, \mathrm{A}}$ & $2.7 \pm 0.6^{\mathrm{a}, \mathrm{A}}$ \\
\hline CAF & & & $5.8 \pm 1.0^{\mathrm{a}, \mathrm{A}}$ \\
\hline Tomba & $48.3 \pm 3.0^{\mathrm{a}, \mathrm{B}}$ & $7.6 \pm 0.6^{\mathrm{a}, \mathrm{A}}$ & $2.8 \pm 0.6^{\mathrm{b}, \mathrm{A}}$ \\
\hline Forest & $52.3 \pm 5.1^{\mathrm{a}, \mathrm{A}}$ & $7.1 \pm 0.6^{\mathrm{a}, \mathrm{A}}$ & \\
\hline
\end{tabular}

\subsubsection{Soil $\mathrm{N}_{2} \mathrm{O}$ emissions}

Soil $\mathrm{N}_{2} \mathrm{O}$ emissions did not differ between forest and CAF at any site $(p=0.06-0.86$; Table 2.2). Similarly, no differences in soil $\mathrm{N}_{2} \mathrm{O}$ emissions were detected among sites for each land use ( $p=0.26-0.44$; Table 2.2). Soil $\mathrm{N}_{2} \mathrm{O}$ emissions exhibited consistent seasonal patterns with larger fluxes in the wet than dry season for both land uses (all $p<0.01 ;$ Fig. 2.4, Tables S2 and S3).

Over the measurement period, soil $\mathrm{N}_{2} \mathrm{O}$ emissions from the forests were positively correlated with soil-air $\mathrm{N}_{2} \mathrm{O}$ concentrations and negatively correlated with $\mathrm{NH}_{4}{ }^{+}$contents (Table 2.3). In the CAF, soil $\mathrm{N}_{2} \mathrm{O}$ emissions were positively correlated with WFPS and soil-air $\mathrm{N}_{2} \mathrm{O}$ 
concentrations, and negatively correlated with air temperatures (Table 2.3). We did not detect any correlation between annual total $\mathrm{N}_{2} \mathrm{O}$ fluxes and soil physical and biochemical characteristics. This was not surprising as the ranges of these soil characteristics were relatively small among sites, which reduce the likelihood that significant correlations will be detected.

\subsubsection{Soil biochemical characteristics}

Soil physical characteristics (clay content, bulk density) did not differ between forest and CAF at any of the sites (Table 2.1). Across sites, Biba Yezoum had lower clay content compared to the other sites for each land use $(p<0.01)$. Generally, the forest showed higher SOC and total $\mathrm{N}$ compared to the CAF $(p<0.01-0.05$; Table 2.1$)$. Soil ${ }^{15} \mathrm{~N}$ natural abundance signatures, as an index of the long-term soil $\mathrm{N}$ availability, were generally similar between the forest and CAF except at Aloum site $(p<0.01$; Table 2.1). Soil $\mathrm{C} / \mathrm{N}$ ratio, another proxy for the long-term soil

$\mathrm{N}$ status, was higher in the forest than in the CAF at all sites $(p<0.01-0.05)$. Soil $\mathrm{pH}$ and exchangeable bases were lower in the forest compared to the CAF at all sites and the converse was true for exchangeable $\mathrm{Al}(p<0.01-0.05$; Table 2.1). Soil ECEC did not differ between the land uses at two sites $(p<0.01$; Table 2.1) and all were low congruent to Ferralsol soils.

\subsection{Discussion}

\subsubsection{Stem and soil $\mathrm{N}_{2} \mathrm{O}$ emissions from the forest}

There has been no study on tree-stem $\mathrm{N}_{2} \mathrm{O}$ emission from Africa, nor has any study on soil $\mathrm{N}_{2} \mathrm{O}$ emission with year-long measurements and spatial replication been reported for the Congo Basin. Stems consistently emitted $\mathrm{N}_{2} \mathrm{O}$ in both land uses (Fig. 2.1 and 2.4, Table 2.2), exemplifying that tropical trees on well-drained soils were important contributors of ecosystem $\mathrm{N}_{2} \mathrm{O}$ emission. So far, there are only two tree species of tropical lowland forest reported with measurements of stem $\mathrm{N}_{2} \mathrm{O}$ emissions (Welch et al., 2019). Our present study included 23 tree species and their comparable stem $\mathrm{N}_{2} \mathrm{O}$ emissions, at least from highly weathered Ferralsol 
soils, across sites over a year of measurements provided support to our spatial extrapolation based on DBH of trees in the sites. Mean stem $\mathrm{N}_{2} \mathrm{O}$ fluxes from our study were within the range of those reported for temperate forests (0.01-2.2 $\mu \mathrm{g} \mathrm{N} \mathrm{m}{ }^{-2}$ stem $\mathrm{h}^{-1}$; Díaz-Pinés et al., 2016; Machacova et al., 2016; Wen et al., 2017), but substantially lower than the reported stem $\mathrm{N}_{2} \mathrm{O}$ emissions of 51-759 $\mu \mathrm{g} \mathrm{N} \mathrm{m}^{-2}$ stem $^{-1}$ for a humid forest in Panama (Welch et al., 2019). However, Welch et al. (2019) measured stem $\mathrm{N}_{2} \mathrm{O}$ emissions at a lower stem height $(0.3 \mathrm{~m})$ compared to our study $(1.3 \mathrm{~m})$, which may partly explain their much larger $\mathrm{N}_{2} \mathrm{O}$ emissions, as another study reported that larger $\mathrm{N}_{2} \mathrm{O}$ emissions occur nearer to the stem base of trees (Barba et al., 2019b). Moreover, the consistently higher stem than soil $\mathrm{N}_{2} \mathrm{O}$ emissions found by Welch et al. (2019), which we did not observe in our study, may point to production of $\mathrm{N}_{2} \mathrm{O}$ within the stem (e.g., Lenhart et al., 2019). Nonetheless, such high stem $\mathrm{N}_{2} \mathrm{O}$ emissions as reported by Welch et al. (2019) have not been observed anywhere else under field conditions.

Our annual soil $\mathrm{N}_{2} \mathrm{O}$ emissions from forests (Table 2.2) were lower than the reported global average for humid tropical forests $\left(2.81 \mathrm{~kg} \mathrm{~N} \mathrm{ha}^{-1} \mathrm{yr}^{-1}\right.$; summarised by Castaldi et al., 2013). In contrast, the $\mathrm{N}_{2} \mathrm{O}$ emissions from our forest soils were comparable to those reported for lowland forests on Ferralsol soils in Panama (0.35-1.07 $\mathrm{kg} \mathrm{N} \mathrm{ha}^{-1} \mathrm{yr}^{-1}$; Matson et al., 2017), and lowland forests on Acrisol soils in Indonesia (0.9 \& $1.0 \mathrm{~kg} \mathrm{~N} \mathrm{ha}^{-1} \mathrm{yr}^{-1}$; Hassler et al., 2017). These were possibly due to the generally similar soil $\mathrm{N}$ availability in our forest sites as these forest sites in Panama and Indonesia, indicated by their comparable soil mineral $\mathrm{N}$ contents and soil ${ }^{15} \mathrm{~N}$ natural abundance signatures.

In comparison with studies from sub-Saharan Africa, annual soil $\mathrm{N}_{2} \mathrm{O}$ emissions from our forests were lower than the annual $\mathrm{N}_{2} \mathrm{O}$ emissions reported for the Mayombe forest in Congo (2.9 $\mathrm{kg} \mathrm{N} \mathrm{ha}^{-1} \mathrm{yr}^{-1}$; Serca et al., 1994), Kakamega mountain rainforest in Kenya (2.6 kg $\mathrm{N} \mathrm{ha}^{-1} \mathrm{yr}^{-1}$; Werner et al., 2007), and Ankasa rainforest in Ghana (2.3 $\mathrm{kg} \mathrm{N} \mathrm{ha}^{-1} \mathrm{yr}^{-1}$; Castaldi 
et al., 2013), but similar in magnitude as those reported for Mau Afromontane forest in Kenya (1.1 $\mathrm{kg} \mathrm{N} \mathrm{ha}^{-1} \mathrm{yr}^{-1}$; Wanyama et al., 2018). Although these African sites have similar precipitation level and highly weathered acidic soils as our study sites, the Kakamega rainforest in Kenya had higher SOC (7.9-20\%) and N contents (0.5-1.6\%) in the topsoil layer compared to our forest sites $(2.8-4.7 \%$ SOC, $0.2-0.4 \%$ total $\mathrm{N})$, which may explain its correspondingly higher soil $\mathrm{N}_{2} \mathrm{O}$ emissions. The study in Congo (Serca et al., 1994), however, was conducted only in a short campaign (two rainy months and one dry month) with less sampling frequency and spatial replication, which may not be a good representation of the spatial and temporal dynamics of soil $\mathrm{N}_{2} \mathrm{O}$ fluxes to achieve annual and large-scale estimate.

\subsubsection{Source of tree-stem $\mathrm{N}_{2} \mathrm{O}$ emissions and their contribution to total (soil + stem) $\mathrm{N}_{2} \mathrm{O}$ emissions}

Emitted $\mathrm{N}_{2} \mathrm{O}$ from stems were found to originate predominantly from $\mathrm{N}_{2} \mathrm{O}$ produced in the soil, as shown by the ${ }^{15} \mathrm{~N}$ tracing experiment (Fig. 2.5). Additionally, the positive correlations of stem $\mathrm{N}_{2} \mathrm{O}$ emissions with soil-air $\mathrm{N}_{2} \mathrm{O}$ concentrations and soil $\mathrm{N}_{2} \mathrm{O}$ emissions (Table 2.3) suggest that the seasonal variation in stem $\mathrm{N}_{2} \mathrm{O}$ emissions (Fig. 2.4, Table S2.2) was likely driven by the temporal dynamics of produced $\mathrm{N}_{2} \mathrm{O}$ in the soil, which partly supported our second hypothesis. While there has been suggestions of within-tree $\mathrm{N}_{2} \mathrm{O}$ production (e.g., Lenhart et al., 2019), our finding from the ${ }^{15} \mathrm{~N}$ tracing experiment, combined with the correlations of stem $\mathrm{N}_{2} \mathrm{O}$ emissions with VPD and air temperature, pointed to a transport mechanism of dissolved $\mathrm{N}_{2} \mathrm{O}$ in soil water by transpiration stream, which has been reported to be important for upland trees that do not have aerenchyma (Machacova et al., 2016; Wen et al., 2017; Welch et al., 2019).

The contributions of up-scaled stem $\mathrm{N}_{2} \mathrm{O}$ emissions from our studied forests to total (soil + stem) $\mathrm{N}_{2} \mathrm{O}$ emissions (Table 2.2) were higher than those reported for temperate forests (1- 
18\%; Díaz-Pinés et al., 2016; Machacova et al., 2016; Wen et al., 2017). Given the higher stem $\mathrm{N}_{2} \mathrm{O}$ emissions in the wet than dry seasons (Table S2.2), coupled with the fact that we consistently measured positive fluxes or net stem $\mathrm{N}_{2} \mathrm{O}$ emissions throughout our measurement period (Fig. 2.4), we conclude that tree stems in these well-drained Ferralsol soils were efficient conduits for releasing $\mathrm{N}_{2} \mathrm{O}$ from the soil. This has significant implications especially during the rainy season as this pathway bypasses the chance for complete denitrification $\left(\mathrm{N}_{2} \mathrm{O}\right.$ to $\mathrm{N}_{2}$ reduction) in the soil.

\subsubsection{Factors controlling temporal variability of stem and soil $\mathrm{N}_{2} \mathrm{O}$ fluxes}

The positive correlation of stem $\mathrm{N}_{2} \mathrm{O}$ emissions with VPD and air temperature in the forest suggests for transport of $\mathrm{N}_{2} \mathrm{O}$ via sap flow, for which the latter had been shown to be stimulated with increasing VPD and air temperature (O’Brien et al., 2004; McJannet et al., 2007). Soil water containing dissolved $\mathrm{N}_{2} \mathrm{O}$ is transported through the xylem via the transpiration stream and eventually emitted from the stem surface to the atmosphere (Díaz-Pinés et al., 2016; Welch et al., 2019; Wen et al., 2017).

Soil moisture has been shown to affect strongly the seasonal variation of soil $\mathrm{N}_{2} \mathrm{O}$ emissions from tropical ecosystems, with increases in soil $\mathrm{N}_{2} \mathrm{O}$ emissions by predominantly denitrification process at high WFPS (Werner et al., 2006; Koehler et al., 2009b; Corre et al., 2014; Matson et al., 2017). The larger stem $\mathrm{N}_{2} \mathrm{O}$ emissions from the forest and soil $\mathrm{N}_{2} \mathrm{O}$ emissions from both land uses in the wet than the dry seasons (Tables S2.2 and S2.3) signified the favourable soil $\mathrm{N}_{2} \mathrm{O}$ production during the wet season, which suggests that denitrification was the dominant $\mathrm{N}_{2} \mathrm{O}$-producing process. However, the moderate WFPS across the year (Table 2.4) suggests that nitrification may also have contributed to $\mathrm{N}_{2} \mathrm{O}$ emissions, especially at Biba Yezoum (with lower rainfall and clay contents; Tables 2.1 and S21) where the low WFPS (Table 2.4) likely favoured nitrification (Corre et al., 2014). For the forest, the negative 
correlation of the stem and soil $\mathrm{N}_{2} \mathrm{O}$ emissions with soil $\mathrm{NH}_{4}{ }^{+}$(Table 2.3) may be indicative of a conservative soil $\mathrm{N}$ cycle in our forest sites, as supported by the dominance of soil $\mathrm{NH}_{4}{ }^{+}$over $\mathrm{NO}_{3}{ }^{-}$(Table 2.4) and by the lower soil $\mathrm{N}_{2} \mathrm{O}$ emissions at our sites compared to $\mathrm{NO}_{3}{ }^{-}$-dominated systems (Davidson et al., 2000a). Although the soil mineral $\mathrm{N}$ content alone does not indicate the $\mathrm{N}$-supplying capacity of the soil, the relative contents of $\mathrm{NH}_{4}^{+}$over $\mathrm{NO}_{3}{ }^{-}$can be a good indicator of whether the soil- $\mathrm{N}$ cycling is conservative with low $\mathrm{N}_{2} \mathrm{O}$ losses or increasingly leaky (Corre et al., 2010, 2014).

\subsubsection{Land-use change effects on soil $\mathrm{N}_{2} \mathrm{O}$ emissions}

The annual soil $\mathrm{N}_{2} \mathrm{O}$ emissions from CAF (Table 2.2) were comparable with those reported for rubber agroforestry in Indonesia (0.6-1.2 $\mathrm{kg} \mathrm{N} \mathrm{ha}^{-1} \mathrm{yr}^{-1}$; Hassler et al., 2017) and from multistrata agroforestry systems in Peru (0.6 kg N ha-1 $\mathrm{yr}^{-1}$; Palm et al., 2002). However, our soil $\mathrm{N}_{2} \mathrm{O}$ emissions from $\mathrm{CAF}$ were higher than those from an extensively managed homegarden in Tanzania (0.35 $\mathrm{kg} \mathrm{N} \mathrm{ha}^{-1} \mathrm{yr}^{-1}$; Gütlein et al., 2018). In a review, Kim et al. (2016b) reported mean annual $\mathrm{N}_{2} \mathrm{O}$ emission from tropical agroforestry systems to be $7.7 \mathrm{~kg} \mathrm{~N}$ $\mathrm{ha}^{-1} \mathrm{yr}^{-1}$. Most of the data used in their review were from intensively managed agroforestry systems with varied fertilizer inputs, which were absent in our extensively managed CAF systems. In line with this, our measured soil $\mathrm{N}_{2} \mathrm{O}$ emissions from the CAF were also lower than the emissions reported for 10-23-year old CAF in Indonesia $\left(3.1 \mathrm{~kg} \mathrm{~N} \mathrm{ha}^{-1} \mathrm{yr}^{-1}\right.$; Veldkamp et al., 2008). Our measured $\mathrm{N}_{2} \mathrm{O}$ emissions provide the first estimates for traditional CAF systems in Africa, as these production systems were not represented in extrapolation of GHG budgets despite their extensive coverage in Africa.

Soil $\mathrm{N}_{2} \mathrm{O}$ emissions did not differ between forest and CAF systems, which supported our first hypothesis. This is possibly due to the presence of leguminous trees in both systems (Table S2.1), which can compensate for $\mathrm{N}$ export from harvest and other losses (Erickson et 
al., 2002; Veldkamp et al., 2008). Although studies have hinted on increased $\mathrm{N}_{2} \mathrm{O}$ emissions from managed systems that utilize leguminous trees as cover crops (Veldkamp et al., 2008), the similar abundance of leguminous trees between forest and CAF at our sites may have offset this effect (Table S1). Previous studies have indeed reported similar soil $\mathrm{N}_{2} \mathrm{O}$ fluxes between reference forests and unfertilized agroforestry systems (Van Lent et al., 2015). Despite the general absence of heavy soil physical disturbance, cultivation and fertilization in these traditional CAF systems, some soil biochemical characteristics have decreased (Table 2.1); however, these did not translate into detectable differences in soil $\mathrm{N}_{2} \mathrm{O}$ emissions with those from forest.

\subsection{Implications}

The biophysical conditions of our forest sites were representative of approximately two-thirds of the rainforest area in the Congo Basin $\left(1.137 \times 10^{6} \mathrm{~km}^{2}\right.$; Fig. 3), considering the same Ferralsol soils, similar elevation $(\leq 1000 \mathrm{~m}$ asl), and annual rainfall between 1,500 and 2,100 $\mathrm{mm} \mathrm{yr}^{-1}$. Using the total (soil + stem) $\mathrm{N}_{2} \mathrm{O}$ emission from our forest sites $\left(1.55 \pm 0.20 \mathrm{~N}_{2} \mathrm{O}-\mathrm{N}\right.$ $\mathrm{kg} \mathrm{ha}^{-1} \mathrm{yr}^{-1}$; Table 2.2), our extrapolated emission for the two-thirds of the Congo Basin was $0.18 \pm 0.05 \mathrm{Tg} \mathrm{N}_{2} \mathrm{O}-\mathrm{N} \mathrm{yr}^{-1}$ (error estimate is the 95\% confidence interval). This accounted $52 \%$ of the earlier estimate of soil $\mathrm{N}_{2} \mathrm{O}$ emissions from tropical rainforests in Africa $\left(0.34 \mathrm{Tg} \mathrm{N} \mathrm{N}_{2} \mathrm{O}\right.$ $\mathrm{N} \mathrm{yr}^{-1}$; Werner et al., 2007), or $27 \%$ based on the more recent estimate $\left(0.65 \mathrm{Tg} \mathrm{N}_{2} \mathrm{O}-\mathrm{N} \mathrm{yr}^{-1}\right.$; Valentini et al., 2014). We acknowledge, however, that there are uncertainties in our extrapolation (as is the case of these cited estimates) because our up-scaling approach from plot to regional level did not account for the spatial variability of large-scale drivers of soil $\mathrm{N}_{2} \mathrm{O}$ emissions, such as soil texture, landforms and vegetation characteristics (e.g. Corre et al., 1999). These limitations of our estimate of $\mathrm{N}_{2} \mathrm{O}$ source strength for the Congo Basin rainforests call for further investigations in Africa to address the geographic bias of studies in the tropical region (e.g. Powers et al., 2011). 
Our year-round measurements of stem and soil $\mathrm{N}_{2} \mathrm{O}$ fluxes were the first detailed study carried out in the Congo Basin, with key implications on improved estimates of $\mathrm{N}_{2} \mathrm{O}$ budget for Africa. Our results revealed that trees on well-drained, highly weathered soils served as an important $\mathrm{N}_{2} \mathrm{O}$ emission pathway, with the potential to overlook up to $38 \%$ of $\mathrm{N}_{2} \mathrm{O}$ emissions if trees are not considered in the ecosystem $\mathrm{N}_{2} \mathrm{O}$ budget. Additionally, forest conversion to traditional, mature ( $>20$ years old) CAF systems had no effect on stem and soil $\mathrm{N}_{2} \mathrm{O}$ emissions, because of similarities in soil moisture and soil texture, absence of fertilizer application, and comparable abundance of leguminous trees in both land uses, which can compensate for $\mathrm{N}$ export from harvest or other losses. Further multi-temporal and spatially replicated studies are needed to provide additional insights on the effect of forest conversion to other land uses on GHG fluxes from the African continent in order to improve GHG budget estimations for the region.

\subsection{Acknowledgements}

This study was funded by the German Research Foundation (DFG, VE 219/14-1, STR 1375/11). We gratefully acknowledge our counterparts in Cameroon, the International Institute for Tropical Agriculture (IITA) and Dr. Rachid Hanna, for granting us access and use of their storage facilities. We are especially grateful to our Cameroonian field assistant Leonel Boris Gadjui Youatou for assisting in the coordination of the project. Many thanks to Narcis Lekeng, Yannick Eyenga Alfred, Denis Djiyo and all the field workers for their great support with field measurements, as well as Raphael Manu for helping with the GIS work and Rodine Tchiofo Lontsi for many discussions on soil processes and Cameroonian settings. We also thank the village leaders and local plot owners for granting us access to their forest and cacao farms. We thank Andrea Bauer, Kerstin Langs, Martina Knaust and Lars Szwec for their assistance with laboratory analyses. 


\subsection{References}

Abada Mbolo, M. M., Zekeng, J. C., Mala, W. A., Fobane, J. L., Djomo Chimi, C., Tangboulou Ngavounsia, ... Tamanjong, Y. V. (2016). The role of cocoa agroforestry systems in conserving forest tree diversity in the Central region of Cameroon. Agroforestry Systems, 90(4), 577-590. https://doi.org/10.1007/s10457-016-9945-8

Allen, R. G., Pereira, L. S., Raes, D., \& Smith, M. (1998). Determination of ET 0 , crop evapotranspiration. Guidelines for Computing Crop Water Requirements-FAO Irrigation and Drainage Paper 56, 309. Retrieved from http://www.hidmet.gov.rs/podaci/agro/table of contens_files.pdf

Barba, J., Poyatos, R., \& Vargas, R. (2019). Automated measurements of greenhouse gases fluxes from tree stems and soils: magnitudes, patterns and drivers. Scientific Reports, 9(1), 1-13. https://doi.org/10.1038/s41598-019-39663-8

Bouwman, A. F., Van Der Hoek, K. W., \& Olivier, J. G. J. (1995). Uncertainties in the global source distribution of nitrous oxide. Journal of Geophysical Research, 100(D2), 27852800. https://doi.org/10.1029/94JD02946

Breuer, L., Papen, H., \& Butterbach-Bahl, K. (2000). $\mathrm{N}_{2} \mathrm{O}$ emission from tropical forest soils of Australia. Journal of Geophysical Research Atmospheres, 105(D21), 26353-26367. https://doi.org/10.1029/2000JD900424

Castaldi, S., Bertolini, T., Valente, A., Chiti, T., \& Valentini, R. (2013). Nitrous oxide emissions from soil of an African rain forest in Ghana. Biogeosciences, 10(6), 41794187. https://doi.org/10.5194/bg-10-4179-2013

Climate-Data.org. (2019). Cameroon climate. Retrieved May 21, 2019, from https://en.climate-data.org/africa/cameroon-142/

Corre, M. D., Dechert, G., \& Veldkamp, E. (2006). Soil nitrogen cycling following montane forest conversion in Central Sulawesi, Indonesia. Soil Science Society of America Journal, 70(2), 359-366. https://doi.org/10.2136/sssaj2005.0061

Corre, M. D., Pennock, D. J., Van Kessel, C., \& Elliott, D. K. (1999). Estimation of annual nitrous oxide emissions from a transitional grassland-forest region in Saskatchewan, Canada. Biogeochemistry, 44(1), 29-49. https://doi.org/10.1023/A:1006025907180

Corre, M. D., Sueta, J. P., \& Veldkamp, E. (2014). Nitrogen-oxide emissions from tropical forest soils exposed to elevated nitrogen input strongly interact with rainfall quantity and seasonality. Biogeochemistry, 118(1-3), 103-120. https://doi.org/10.1007/s10533-0139908-3

Corre, M. D., Veldkamp, E., Arnold, J., \& Joseph Wright, S. (2010). Impact of elevated N input on soil $\mathrm{N}$ cycling and losses in old-growth lowland and montane forests in Panama. Ecology, 91(6), 1715-1729. https://doi.org/10.1890/09-0274.1

Crawley, M. J. (2009). The R Book. Chichester, UK: John Wiley \& Sons Ltd.

Curtis, J. T., \& McIntosh, R. P. (1951). An Upland Forest Continuum in the Prairie-Forest Border Region of Wisconsin. Ecology, 32(3), 476-496. https://doi.org/10.2307/1931725 
Davidson, E. A., \& Kanter, D. (2014). Inventories and scenarios of nitrous oxide emissions. Environmental Research Letters, 9(10). https://doi.org/10.1088/1748-9326/9/10/105012

Davidson, E. A., Keller, M., Erickson, H. E., Verchot, L. V., \& Veldkamp, E. (2000). Testing a Conceptual Model of Soil Emissions of Nitrous and Nitric Oxides. BioScience, 50(8), 667. https://doi.org/10.1641/0006-3568(2000)050[0667:tacmos]2.0.co;2

Davidson, E. A., \& Verchot, L. V. (2000). Testing the hole-in-the-pipe model of nitric and nitrous oxide emissions from soils using the TRAGNET database. Global Biogeochemical Cycles, 14(4), 1035-1043. https://doi.org/10.1029/1999GB001223

Denman, K. L., Brasseur, G., Chidthaisong, A., Ciais, P., Cox, P. M., Dickinson, R. E., ... Zhang, X. (2007). Couplings Between Changes in the Climate System and Biogeochemistry. In Climate Change 2007: The Physical Science Basis. Contribution of Working Group I to the Fourth Assessment Report of the Intergovernmental Panel on Climate Change. Cambridge University Press, Cambridge, United Kingdom and New York, NY, USA. Retrieved from https://www.ipcc.ch/site/assets/uploads/2018/02/ar4wg1-chapter7-1.pdf

Díaz-Pinés, E., Heras, P., Gasche, R., Rubio, A., Rennenberg, H., Butterbach-Bahl, K., \& Kiese, R. (2016). Nitrous oxide emissions from stems of ash (Fraxinus angustifolia Vahl) and European beech (Fagus sylvatica L.). Plant and Soil, 398(1-2), 35-45. https://doi.org/https://doi.org/10.1007/s11104-015-2629-8

Dkamela, G. P. (2010). The context of REDD+ in Cameroon: Drivers, agents and institutions (Occasional). CIFOR, Bogor, Indonesia.

Erickson, H. E., Davidson, E. A., \& Keller, M. (2002). Former land-use and tree species affect nitrogen oxide emissions from a tropical dry forest. Oecologia, 130(2), 297-308. https://doi.org/10.1007/s004420100801

FAO/IIASA/ISRIC/ISS-CAS/JRC. (2012). Harmonized World Soil Database (version 1.2). FAO, Rome, Italy and IIASA, Laxenburg, Austria. Retrieved September 13, 2019, from http://webarchive.iiasa.ac.at/Research/LUC/External-World-soil-database/HTML/

Gütlein, A., Gerschlauer, F., Kikoti, I., \& Kiese, R. (2018). Impacts of climate and land use on $\mathrm{N}_{2} \mathrm{O}$ and $\mathrm{CH}_{4}$ fluxes from tropical ecosystems in the Mt. Kilimanjaro region, Tanzania. Global Change Biology, 24, 1239-1255. https://doi.org/10.1111/gcb.13944

Gwanfogbe, M., Meligui, A., Moukam, J., \& Nguoghia, J. (1983). Geography of Cameroon. Macmillan Education Ltd, Hong Kong.

Hassler, E., Corre, M. D., Kurniawan, S., \& Veldkamp, E. (2017). Soil nitrogen oxide fluxes from lowland forests converted to smallholder rubber and oil palm plantations in Sumatra, Indonesia. Biogeosciences, 14(11), 2781-2798. https://doi.org/https://doi.org/10.5194/bg-14-2781-2017

Hassler, E., Corre, M. D., Tjoa, A., Damris, M., Utami, S. R., \& Veldkamp, E. (2015). Soil fertility controls soil-atmosphere carbon dioxide and methane fluxes in a tropical landscape converted from lowland forest to rubber and oil palm plantations. Biogeosciences Discussions, 12(12), 9163-9207. https://doi.org/10.5194/bgd-12-91632015 
Hijmans, R. J., Cameron, S. E., Parra, J. L., Jones, P. G., \& Jarvis, A. (2005). Very high resolution interpolated climate surfaces for global land areas. International Journal of Climatology, 25(15), 1965-1978. https://doi.org/10.1002/joc.1276

Huang, J., Golombeck, A., Prinn, R. G., Weiss, R. F., Fraser, P., Simmonds, P., ... Porter, L. (2008). Estimation of regional emissions of nitrous oxide from 1997 to 2005 using multinetwork measurements, a chemical transport model, and an inverse method. Journal of Geophysical Research Atmospheres, 113(17), 1-19. https://doi.org/10.1029/2007JD009381

Ishizuka, S., Tsuruta, H., \& Murdiyarso, D. (2002). An intensive field study on $\mathrm{CO}_{2}, \mathrm{CH}_{4}$, and $\mathrm{N}_{2} \mathrm{O}$ emissions from soils at four land-use types in Sumatra, Indonesia. Global Biogeochemical Cycles, 16(3), 1049. https://doi.org/10.1029/2001gb001614

IUSS Working Group WRB. (2015). World Reference Base for Soil Resources 2014, update 2015 International soil classification system for naming soils and creating legends for soil maps. World Soil Resources Reports No. 106. FAO, Rome.

Jarvis, A., Reuter, H. I., Nelson, A., \& Guevara, E. (2008). Hole-filled SRTM for the globe, Version 4. CGIAR-CSI SRTM 90m Database. International Center for Tropical Agriculture, Cali, Columbia. Http://Srtm.Csi.Cgiar.Org, (September 2017).

Kiese, R., Hewett, B., Graham, A., \& Butterbach-Bahl, K. (2003). Seasonal variability of $\mathrm{N}_{2} \mathrm{O}$ emissions and $\mathrm{CH}_{4}$ uptake by tropical rainforest soils of Queensland, Australia. Global Biogeochemical Cycles, 17(2), 1043. https://doi.org/10.1029/2002gb002014

Kim, D. G., Thomas, A. D., Pelster, D. E., Rosenstock, T. S., \& Sanz-Cobena, A. (2016). Greenhouse gas emissions from natural ecosystems and agricultural lands in sub-Saharan Africa: Synthesis of available data and suggestions for further research. Biogeosciences, 13(16), 4789-4809. https://doi.org/10.5194/bg-13-4789-2016

Koehler, B., Corre, M. D., Veldkamp, E., Wullaert, H., \& Wright, S. J. (2009). Immediate and long-term nitrogen oxide emissions from tropical forest soils exposed to elevated nitrogen input. Global Change Biology, 15(8), 2049-2066. https://doi.org/10.1111/j.1365-2486.2008.01826.x

Kotto, J. S., Moukam, A., Njomgang, R., Tiki-Manga, T., Tonye, J., Diaw, C., ... Tondoh, J. (2002). Alternatives to slash-and-burn in Indonesia: summary report \& synthesis of phase II in Cameroon. ASB-Indonesia report. Nairobi. Kenya.

Kreuzwieser, J., Buchholz, J., \& Rennenberg, H. (2003). Emission of Methane and Nitrous Oxide by Australian Mangrove Ecosystems. Plant Biology, 5(4), 423-431. https://doi.org/10.1055/s-2003-42712

Kroetsch, D., \& Wang, C. (2008). Particle size distribution. In Soil Sampling and Methods of Analysis, Second Edition (pp. 713-725).

Lenhart, K., Behrendt, T., Greiner, S., Steinkamp, J., Well, R., Giesemann, A., \& Keppler, F. (2019). Nitrous oxide effluxes from plants as a potentially important source to the atmosphere. New Phytologist, 221(3), 1398-1408. https://doi.org/10.1111/nph.15455

Machacova, K., Bäck, J., Vanhatalo, A., Halmeenmäki, E., Kolari, P., Mammarella, I., ... 
Pihlatie, M. (2016). Pinus sylvestris as a missing source of nitrous oxide and methane in boreal forest. Scientific Reports, 6(March), 1-8. https://doi.org/10.1038/srep23410

Machacova, K., Maier, M., Svobodova, K., Lang, F., \& Urban, O. (2017). Cryptogamic stem covers may contribute to nitrous oxide consumption by mature beech trees. Scientific Reports, 7(1), 1-7. https://doi.org/10.1038/s41598-017-13781-7

Machacova, K., Papen, H., Kreuzwieser, J., \& Rennenberg, H. (2013). Inundation strongly stimulates nitrous oxide emissions from stems of the upland tree Fagus sylvatica and the riparian tree Alnus glutinosa. Plant and Soil, 364(1-2), 287-301. https://doi.org/10.1007/s11104-012-1359-4

Matson, A. L., Corre, M. D., Langs, K., \& Veldkamp, E. (2017). Soil trace gas fluxes along orthogonal precipitation and soil fertility gradients in tropical lowland forests of Panama. Biogeosciences, 14(14), 3509-3524. https://doi.org/10.5194/bg-14-3509-2017

McJannet, D., Fitch, P., Disher, M., \& Wallace, J. (2007). Measurements of transpiration in four tropical rainforest types of north Queensland, Australia. HYDROLOGICAL PROCESSES, 21, 3549-3564. https://doi.org/https://doi.org/10.1002/hyp.6576

Müller, A. K., Matson, A. L., Corre, M. D., \& Veldkamp, E. (2015). Soil N ${ }_{2} \mathrm{O}$ fluxes along an elevation gradient of tropical montane forests under experimental nitrogen and phosphorus addition. Frontiers in Earth Science, 3(October), 1-12. https://doi.org/10.3389/feart.2015.00066

Neill, C., Steudler, P. A., Garcia-Montiel, D. C., Melillo, J. M., Feigl, B. J., Piccolo, M. C., \& Cerri, C. C. (2005). Rates and controls of nitrous oxide and nitric oxide emissions following conversion of forest to pasture in Rondônia. Nutrient Cycling in Agroecosystems, 71(1), 1-15. https://doi.org/10.1007/s10705-004-0378-9

O’Brien, J. J., Oberbauer, S. F., \& Clark, D. B. (2004). Whole tree xylem sap flow responses to multiple environmental variables in a wet tropical forest. Plant, Cell and Environment, 27(5), 551-567. https://doi.org/10.1111/j.1365-3040.2003.01160.x

Palm, C. A., Alegre, J. C., Arevalo, L., Mutuo, P. K., Mosier, A. R., \& Coe, R. (2002). Nitrous oxide and methane fluxes in six different land use systems in the Peruvian Amazon. Global Biogeochemical Cycles, 16(4), 1073. https://doi.org/10.1029/2001gb001855

Powers, J. S., Corre, M. D., Twine, T. E., \& Veldkamp, E. (2011). Geographic bias of field observations of soil carbon stocks with tropical land-use changes precludes spatial extrapolation. Proceedings of the National Academy of Sciences of the United States of America, 108(15), 6318-6322. https://doi.org/10.1073/pnas.1016774108

Purbopuspito, J., Veldkamp, E., Brumme, R., \& Murdiyarso, D. (2006). Trace gas fluxes and nitrogen cycling along an elevation sequence of tropical montane forests in Central Sulawesi, Indonesia. Global Biogeochemical Cycles, 20(3), 1-11. https://doi.org/10.1029/2005GB002516

Ravishankara, A. R., Daniel, J. S., \& Portmann, R. W. (2009). Nitrous oxide ( $\left.\mathrm{N}_{2} \mathrm{O}\right)$ : The dominant ozone-depleting substance emitted in the 21st century. Science, 326(5949), 123-125. https://doi.org/10.1126/science.1176985 
Rusch, H., \& Rennenberg, H. (1998). Black alder (Alnus glutinosa (L.) Gaertn.) trees mediate methane and nitrous oxide emission from the soil to the atmosphere. Plant and Soil, 201(1), 1-7. https://doi.org/10.1023/A:1004331521059

Saj, S., Jagoret, P., \& Todem Ngogue, H. (2013). Carbon storage and density dynamics of associated trees in three contrasting Theobroma cacao agroforests of Central Cameroon. Agroforestry Systems, 87(6), 1309-1320. https://doi.org/10.1007/s10457-013-9639-4

Serca, D., Delmas, R., Jambert, C., \& Labroue, L. (1994). Emissions of nitrogen oxides from equatorial rain forest in central Africa: Tellus B: Chemical and Physical Meteorology, 46(4), 243-254. https://doi.org/10.3402/tellusb.v46i4.15795

Sonwa, D. J., Nkongmeneck, B. A., Weise, S. F., Tchatat, M., Adesina, A. A., \& Janssens, M. J. J. (2007). Diversity of plants in cocoa agroforests in the humid forest zone of Southern Cameroon. Biodiversity and Conservation, 16(8), 2385-2400. https://doi.org/10.1007/s10531-007-9187-1

Tchiofo Lontsi, R., Corre, M. D., van Straaten, O., \& Veldkamp, E. (2019). Changes in soil organic carbon and nutrient stocks in conventional selective logging versus reducedimpact logging in rainforests on highly weathered soils in Southern Cameroon. Forest Ecology and Management, 451(August), 117522. https://doi.org/10.1016/j.foreco.2019.117522

Thompson, R. L., Chevallier, F., Crotwell, A. M., Dutton, G., Langenfelds, R. L., Prinn, R. G., ... Aoki, S. (2014). Nitrous oxide emissions 1999 to 2009 from a global atmospheric inversion. Atmospheric Chemistry and Physics, 14(4), 1801-1817. https://doi.org/10.5194/acp-14-1801-2014

Valentini, R., Arneth, A., Bombelli, A., Castaldi, S., Cazzolla Gatti, R., Chevallier, F., ... Scholes, R. J. (2014). A full greenhouse gases budget of africa: Synthesis, uncertainties, and vulnerabilities. Biogeosciences, 11(2), 381-407. https://doi.org/10.5194/bg-11-3812014

Van Lent, J., Hergoualc'H, K., \& Verchot, L. V. (2015). Reviews and syntheses: Soil $\mathrm{N}_{2} \mathrm{O}$ and NO emissions from land use and land-use change in the tropics and subtropics: A meta-analysis. Biogeosciences, 12(23), 7299-7313. https://doi.org/10.5194/bg-12-72992015

van Straaten, O., Corre, M. D., Wolf, K., Tchienkoua, M., Cuellar, E., Matthews, R. B., \& Veldkamp, E. (2015). Conversion of lowland tropical forests to tree cash crop plantations loses up to one-half of stored soil organic carbon. Proceedings of the National Academy of Sciences, 112(32), 9956-9960. https://doi.org/10.1073/pnas.1504628112

Veldkamp, E. (1994). Organic Carbon Turnover in Three Tropical Soils under Pasture after Deforestation. Soil Science Society of America Journal, 58(1), 175-180. https://doi.org/10.2136/sssaj1994.03615995005800010025x

Veldkamp, E., Koehler, B., \& Corre, M. D. (2013). Indications of nitrogen-limited methane uptake in tropical forest soils. Biogeosciences, 10(8), 5367-5379.

https://doi.org/10.5194/bg-10-5367-2013 
Veldkamp, E., Purbopuspito, J., Corre, M. D., Brumme, R., \& Murdiyarso, D. (2008). Land use change effects on trace gas fluxes in the forest margins of Central Sulawesi, Indonesia. Journal of Geophysical Research: Biogeosciences, 113(2), 1-11. https://doi.org/10.1029/2007JG000522

Verchot, L. V., Hutabarat, L., Hairiah, K., \& van Noordwijk, M. (2006). Nitrogen availability and soil $\mathrm{N}_{2} \mathrm{O}$ emissions following conversion of forests to coffee in southern Sumatra. Global Biogeochemical Cycles, 20(4), 1-12. https://doi.org/10.1029/2005GB002469

Wanyama, I., Pelster, D. E., Arias-Navarro, C., Butterbach-Bahl, K., Verchot, L. V., \& Rufino, M. C. (2018). Management intensity controls soil $\mathrm{N}_{2} \mathrm{O}$ fluxes in an Afromontane ecosystem. Science of the Total Environment, 624(December), 769-780. https://doi.org/10.1016/j.scitotenv.2017.12.081

Welch, B., Gauci, V., \& Sayer, E. J. (2019). Tree stem bases are sources of $\mathrm{CH}_{4}$ and $\mathrm{N}_{2} \mathrm{O}$ in a tropical forest on upland soil during the dry to wet season transition. Global Change Biology, 25(1), 361-372. https://doi.org/10.1111/gcb.14498

Wen, Y., Corre, M. D., Rachow, C., Chen, L., \& Veldkamp, E. (2017). Nitrous oxide emissions from stems of alder, beech and spruce in a temperate forest. Plant Soil. https://doi.org/10.1007/s11104-017-3416-5

Werner, C., Butterbach-Bahl, K., Haas, E., Hickler, T., \& Kiese, R. (2007a). A global inventory of $\mathrm{N}_{2} \mathrm{O}$ emissions from tropical rainforest soils using a detailed biogeochemical model. Global Biogeochemical Cycles, 21(3). https://doi.org/10.1029/2006GB002909

Werner, C., Kiese, R., \& Butterbach-Bahl, K. (2007b). Soil-atmosphere exchange of $\mathrm{N}_{2} \mathrm{O}$, $\mathrm{CH}_{4}$, and $\mathrm{CO}_{2}$ and controlling environmental factors for tropical rain forest sites in western Kenya. Journal of Geophysical Research, 112(3), D03308. https://doi.org/10.1029/2006JD007388

Werner, C., Zheng, X., Tang, J., Xie, B., Liu, C., Kiese, R., \& Butterbach-Bahl, K. (2006). $\mathrm{N}_{2} \mathrm{O}, \mathrm{CH}_{4}$ and $\mathrm{CO}_{2}$ emissions from seasonal tropical rainforests and a rubber plantation in Southwest China. Plant and Soil, 289(1-2), 335-353. https://doi.org/10.1007/s11104006-9143-y

Wolf, K., Veldkamp, E., Homeier, J., \& Martinson, G. O. (2011). Nitrogen availability links forest productivity, soil nitrous oxide and nitric oxide fluxes of a tropical montane forest in southern Ecuador. Global Biogeochemical Cycles, 25(4), GB4009. https://doi.org/10.1029/2010GB003876

Zapfack, L., Engwald, S., Sonke, B., Achoundong, G., \& Madong, B. A. (2002). The impact of land conversion on plant biodiversity in the forest zone of Cameroon. Biodiversity and Conservation, 11(11), 2047-2061. https://doi.org/https://doi.org/10.1023/A:1020861925294 


\subsection{Appendix}

Table S2.1. Vegetation and site characteristics of the study sites on highly weathered soils in the Congo Basin, Cameroon.

\begin{tabular}{|c|c|c|c|c|c|c|}
\hline Site & \multicolumn{2}{|c|}{ Aloum } & \multicolumn{2}{|c|}{ Biba Yezoum } & \multicolumn{2}{|c|}{ Tomba } \\
\hline Land use & Forest & $\begin{array}{l}\text { Cacao } \\
\text { agroforestry }\end{array}$ & Forest & $\begin{array}{l}\text { Cacao } \\
\text { agroforestry }\end{array}$ & Forest & $\begin{array}{l}\text { Cacao } \\
\text { agroforestry }\end{array}$ \\
\hline Tree density $\left(\mathrm{n} \mathrm{ha}^{-1}\right)$ & $594 \pm 29$ & $\begin{array}{l}403 \pm 60 \\
(140 \pm 37)\end{array}$ & $619 \pm 16$ & $\begin{array}{l}267 \pm 24 \\
(96 \pm 16)\end{array}$ & $453 \pm 34$ & $\begin{array}{l}430 \pm 51 \\
(292 \pm 79)\end{array}$ \\
\hline $\begin{array}{l}\text { Total basal area }\left(\mathrm{m}^{2}\right. \\
\left.\mathrm{ha}^{-1}\right)\end{array}$ & $35 \pm 1.4$ & $\begin{array}{l}27 \pm 2.5 \\
(1.5 \pm 0.5)\end{array}$ & $33 \pm 2.9$ & $\begin{array}{l}27 \pm 2.0 \\
(0.9 \pm 0.2)\end{array}$ & $34 \pm 2.3$ & $\begin{array}{l}30 \pm 3.2 \\
(3.8 \pm 1.3)\end{array}$ \\
\hline $\begin{array}{l}\text { Legume abundance } \\
\text { ( } \% \text { of the number of } \\
\text { trees) }\end{array}$ & $7.7 \pm 1.7$ & $5.9 \pm 1.4$ & $9.3 \pm 1.9$ & $6.5 \pm 2.3$ & $7.4 \pm 1.6$ & $4.8 \pm 1.4$ \\
\hline Tree height (m) & $18.6 \pm 0.5$ & $\begin{array}{l}15.1 \pm 0.9 \\
(6.8 \pm 0.1)\end{array}$ & $20.6 \pm 0.5$ & $\begin{array}{l}16.1 \pm 0.4 \\
(6.2 \pm 0.3)\end{array}$ & $19.5 \pm 0.4$ & $\begin{array}{l}11.7 \pm 1.7 \\
(6.1 \pm 0.3)\end{array}$ \\
\hline \multirow[t]{2}{*}{$\begin{array}{l}\text { Diameter at breast } \\
\text { height }(\mathrm{cm})\end{array}$} & $23.2 \pm 0.6$ & $23.3 \pm 1.6$ & $22.6 \pm 0.8$ & $27.2 \pm 0.2$ & $24.8 \pm 1.0$ & $23.5 \pm 2.7$ \\
\hline & & $(11.4 \pm 0.2)$ & & $(10.8 \pm 0.2)$ & & $(12.3 \pm 0.6)$ \\
\hline \multirow{2}{*}{$\begin{array}{l}\text { Three most abundant } \\
\text { tree species in the } \\
\text { forest plots at each } \\
\text { site }^{b}\end{array}$} & \multicolumn{2}{|c|}{ Cleistopholis patens } & \multicolumn{2}{|l|}{ Celtis sp. } & \multicolumn{2}{|l|}{ Celtis sp. } \\
\hline & \multicolumn{2}{|c|}{ Pycnanthus angolensis } & \multicolumn{2}{|c|}{$\begin{array}{l}\text { Petersianthus } \\
\text { macrocarpus }\end{array}$} & \multicolumn{2}{|c|}{ Funtumia elastica } \\
\hline $\begin{array}{l}\text { Elevation (m above } \\
\text { sea level) }\end{array}$ & \multicolumn{2}{|r|}{651} & \multicolumn{2}{|r|}{674} & \multicolumn{2}{|c|}{752} \\
\hline $\begin{array}{l}\text { Precipitation (mm } \\
\mathrm{yr}^{-1} \text {; from } 1982 \text { to } \\
2012)^{\mathrm{c}}\end{array}$ & \multicolumn{2}{|r|}{2064} & \multicolumn{2}{|c|}{1639} & \multicolumn{2}{|c|}{1577} \\
\hline
\end{tabular}

Note. All vegetation characteristics were determined from trees with $\geq 10 \mathrm{~cm}$ diameter at breast height in both forest and cacao agroforestry.

${ }^{\text {a }}$ For cacao agroforestry, the first values are for both cacao and remnant shade trees, and the second values in parentheses are for cacao trees only.

${ }^{\mathrm{b}}$ Determined using Importance Value Index (IVI = relative density + relative frequency + relative dominance (Curtis and McIntosh, 1951)).

${ }^{c}$ Climate-Data.org, 2019 
Table S2.2. Seasonal mean ( \pm SE, $n=4)$ water-filled pore space (WFPS), extractable mineral $\mathrm{N}$ (measured in the top $5 \mathrm{~cm}$ of soil) and nitrous oxide $\left(\mathrm{N}_{2} \mathrm{O}\right)$ fluxes in forests on highly weathered soils in the Congo Basin, Cameroon. Means followed by different lowercase letters indicate significant differences between seasons for each site (linear mixed-effect models with Tukey's HSD at $p \leq 0.05$ ).

\begin{tabular}{|c|c|c|c|c|c|}
\hline $\begin{array}{l}\text { Site/ } \\
\text { season }\end{array}$ & 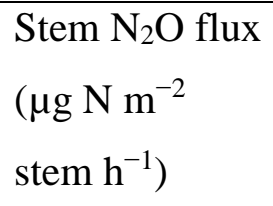 & $\begin{array}{l}\text { Soil } \mathrm{N}_{2} \mathrm{O} \text { flux } \\
\left(\mu \mathrm{g} \mathrm{N} \mathrm{m}^{-2} \mathrm{~h}^{-1}\right)\end{array}$ & $\begin{array}{l}\text { WFPS } \\
(\%)\end{array}$ & $\begin{array}{l}{\text { Soil } \mathrm{NH}_{4}+}^{+} \\
(\mathrm{mg} \mathrm{N} \\
\left.\mathrm{kg}^{-1}\right)\end{array}$ & $\begin{array}{l}\mathrm{Soil} \mathrm{NO}_{3}^{-} \\
(\mathrm{mg} \mathrm{N} \\
\left.\mathrm{kg}^{-1}\right)\end{array}$ \\
\hline \multicolumn{6}{|l|}{ Wet seasson } \\
\hline Aloum & $1.56 \pm 0.36^{\mathrm{a}}$ & $16.7 \pm 3.7^{\mathrm{a}}$ & $66.2 \pm 2.2^{\mathrm{a}}$ & $6.0 \pm 0.6^{\mathrm{a}}$ & $6.0 \pm 0.8^{\mathrm{a}}$ \\
\hline Biba Yezoum & $2.92 \pm 0.73^{\mathrm{a}}$ & $22.9 \pm 4.9^{\mathrm{a}}$ & $44.8 \pm 2.6^{\mathrm{a}}$ & $4.4 \pm 0.3^{\mathrm{a}}$ & $2.2 \pm 0.2^{b}$ \\
\hline Tomba & $1.01 \pm 0.13^{\mathrm{a}}$ & $18.6 \pm 2.2^{\mathrm{a}}$ & $49.4 \pm 1.8^{\mathrm{a}}$ & $6.9 \pm 0.5^{b}$ & $5.4 \pm 0.8^{a}$ \\
\hline \multicolumn{6}{|l|}{ Dry season } \\
\hline Aloum & $0.61 \pm 0.14^{b}$ & $10.0 \pm 1.8^{\mathrm{b}}$ & $62.0 \pm 3.6^{\mathrm{a}}$ & $8.7 \pm 1.3^{\mathrm{a}}$ & $6.6 \pm 1.0^{\mathrm{a}}$ \\
\hline Biba Yezoum & $1.73 \pm 0.57^{b}$ & $10.3 \pm 1.4^{\mathrm{b}}$ & $36.3 \pm 3.2^{\mathrm{a}}$ & $5.5 \pm 0.4^{\mathrm{a}}$ & $3.6 \pm 0.5^{\mathrm{a}}$ \\
\hline Tomba & $0.69 \pm 0.15^{\mathrm{b}}$ & $8.9 \pm 1.9^{b}$ & $46.2 \pm 3.1^{\mathrm{a}}$ & $8.7 \pm 0.8^{\mathrm{a}}$ & $6.5 \pm 1.1^{\mathrm{a}}$ \\
\hline
\end{tabular}

Table S2.3. Seasonal mean ( \pm SE, $n=4)$ water-filled pore space (WFPS), extractable mineral $\mathrm{N}$ (measured in the top $5 \mathrm{~cm}$ of soil) and nitrous oxide $\left(\mathrm{N}_{2} \mathrm{O}\right)$ fluxes in cacao agroforestry sites located on highly weathered soils in the Congo Basin, Cameroon. Means followed by different lowercase letters indicate significant differences between seasons for each site (linear mixedeffect models with Tukey's HSD at $p \leq 0.05$ ).

\begin{tabular}{llllll}
\hline $\begin{array}{l}\text { Site/ } \\
\text { season }\end{array}$ & $\begin{array}{l}\text { Stem N } 2 \mathrm{O} \text { flux } \\
\left(\mu \mathrm{g} \mathrm{N} \mathrm{m}^{-2}\right. \\
\left.\mathrm{stem} \mathrm{h}^{-1}\right)\end{array}$ & $\begin{array}{l}\text { Soil N} \mathrm{O}_{2} \text { flux } \\
\left(\mu \mathrm{g} \mathrm{m}^{-2} \mathrm{~h}^{-1}\right)\end{array}$ & $\begin{array}{l}\text { WFPS } \\
(\%)\end{array}$ & $\begin{array}{l}\text { Soil NH}_{4}{ }^{+} \\
(\mathrm{mg} \mathrm{N} \\
\left.\mathrm{kg}^{-1}\right)\end{array}$ & $\begin{array}{l}\text { Soil NO }^{-} \\
\left(\mathrm{mg} \mathrm{N} \mathrm{kg}^{-1}\right)\end{array}$ \\
\hline Wet season & & & & \\
\hline Aloum & $1.21 \pm 0.27^{\mathrm{a}}$ & $22.6 \pm 4.7^{\mathrm{a}}$ & $60.3 \pm 1.6^{\mathrm{a}}$ & $4.3 \pm 0.4^{\mathrm{a}}$ & $2.1 \pm 0.4^{\mathrm{a}}$ \\
Biba Yezoum & $1.43 \pm 0.36^{\mathrm{a}}$ & $15.0 \pm 3.5^{\mathrm{a}}$ & $38.2 \pm 1.7^{\mathrm{a}}$ & $7.0 \pm 0.6^{\mathrm{a}}$ & $2.2 \pm 0.4^{\mathrm{a}}$ \\
Tomba & $1.05 \pm 0.18^{\mathrm{a}}$ & $21.2 \pm 2.6^{\mathrm{a}}$ & $53.4 \pm 2.4^{\mathrm{a}}$ & $7.3 \pm 0.8^{\mathrm{a}}$ & $2.5 \pm 0.3^{\mathrm{a}}$ \\
\hline Dry season & & & & & \\
\hline Aloum & $0.53 \pm 0.07^{\mathrm{b}}$ & $6.4 \pm 0.7^{\mathrm{b}}$ & $51.7 \pm 1.9^{\mathrm{b}}$ & $6.0 \pm 1.0^{\mathrm{a}}$ & $2.7 \pm 0.6^{\mathrm{a}}$ \\
Biba Yezoum & $0.74 \pm 0.12^{\mathrm{a}}$ & $5.3 \pm 1.3^{\mathrm{b}}$ & $25.9 \pm 1.8^{\mathrm{b}}$ & $7.5 \pm 0.6^{\mathrm{a}}$ & $3.2 \pm 0.7^{\mathrm{a}}$ \\
Tomba & $0.63 \pm 0.06^{\mathrm{a}}$ & $6.2 \pm 1.2^{\mathrm{b}}$ & $50.4 \pm 6.2^{\mathrm{a}}$ & $6.9 \pm 0.9^{\mathrm{a}}$ & $3.4 \pm 0.7^{\mathrm{a}}$ \\
\hline
\end{tabular}




\title{
CHAPTER 3
}

\section{TREE STEM AND SOIL METHANE AND CARBON DIOXIDE FLUXES FROM RAINFOREST AND CACAO AGROFOREST ON HIGHLY WEATHERED SOILS IN THE CONGO BASIN}

\begin{abstract}
Najeeb A. Iddris ${ }^{1}$, Marife D. Corre ${ }^{1}$, Oliver van Straaten $^{1,2}$, Rodine Tchiofo Lontsi ${ }^{1}$, Edzo Veldkamp $^{1}$
\end{abstract}

${ }^{1}$ Soil Science of Tropical and Subtropical Ecosystems, University of Goettingen, Goettingen, Germany

${ }^{2}$ Now at: Northwest German Forest Research Institute, Goettingen, Germany 


\subsection{Abstract}

Despite increasing evidence from the last decade pointing to significant tree-stem $\mathrm{CH}_{4}$ emissions, estimates of $\mathrm{CH}_{4}$ budget from terrestrial ecosystems are still restricted to net fluxes from the soil surface only. The vast majority of tree greenhouse gas (GHG) emission studies have been conducted in tropical wetland forests, but it remains unknown whether trees in tropical lowland forests on heavily weathered soils, are substantial contributors to $\mathrm{CH}_{4}$ emissions. Additionally, despite the availability of data on trace soil GHG fluxes from other parts of the world, very little is known about the effect of land-use change on trace GHG fluxes in natural African ecosystems. Here, we measured stem and soil $\mathrm{CH}_{4}$ fluxes and soil $\mathrm{CO}_{2}$ fluxes with forest conversion to cacao agroforestry in central and southern Cameroon. Stem and soil trace gas fluxes were measured monthly from May 2017 to April 2018. All the studied trees emitted measureable $\mathrm{CH}_{4}$ at some point during the measurement period. The annual stem $\mathrm{CH}_{4}$ emissions were $0.33 \pm 0.06 \mathrm{~kg} \mathrm{C} \mathrm{ha}^{-1} \mathrm{yr}^{-1}$ from the forest and $0.20 \pm 0.03 \mathrm{~kg} \mathrm{C} \mathrm{ha}^{-1} \mathrm{yr}^{-1}$ from cacao agroforestry, whereas the annual soil $\mathrm{CH}_{4}$ uptake was $-2.95 \pm 0.40 \mathrm{~kg} \mathrm{C} \mathrm{ha}^{-1} \mathrm{yr}^{-1}$ for the forest and $-3.42 \pm 0.44 \mathrm{~kg} \mathrm{C} \mathrm{ha}^{-1} \mathrm{yr}^{-1}$ for the cacao agroforestry. Thus, the balance between the soil and stem $\mathrm{CH}_{4}$ fluxes indicated that there was a net $\mathrm{CH}_{4}$ sink in both land uses. Our upscaling suggested that tree emissions offset 5-18\% and 3-14\% of the soil $\mathrm{CH}_{4}$ sink in the forest and cacao agroforestry, respectively. The annual soil $\mathrm{CO}_{2}$ emissions were $10.1 \pm 0.27 \mathrm{Mg} \mathrm{C}^{-1}$ $\mathrm{yr}^{-1}$ for the forest, and $10.3 \pm 0.42 \mathrm{Mg} \mathrm{Cha}^{-1} \mathrm{yr}^{-1}$ for the cacao agroforestry. Forest conversion to traditional, mature cacao agroforestry had no effect on stem and soil trace gas fluxes ( $p=$ $0.12-0.95)$. Overall, our results demonstrate that tropical trees on well drained, highly weathered soils represent potential $\mathrm{CH}_{4}$ emission pathways that have largely been ignored, with stem $\mathrm{CH}_{4}$ emissions constituting a considerable offset of the soil $\mathrm{CH}_{4}$ sink.

Keywords: Africa, cacao agroforest, carbon dioxide, Congo Basin, land-use change, methane, soil respiration, trace greenhouse gases, tree stem emissions, tropical rainforest 


\subsection{Introduction}

Carbon dioxide $\left(\mathrm{CO}_{2}\right)$ and methane $\left(\mathrm{CH}_{4}\right)$ constitute two of the most important trace greenhouse gases (GHG), with $\mathrm{CH}_{4}$ particularly having 32-45 times the global warming potential of $\mathrm{CO}_{2}$ by mass over a century (Neubauer \& Megonigal, 2015). Forest $\mathrm{CO}_{2}$ dynamics feature prominently in global carbon cycle studies, but the role of forests in the $\mathrm{CH}_{4}$ cycle are relatively poorly understood. Although a considerable number of research have been undertaken to constrain the net balance of $\mathrm{CH}_{4}$, the global $\mathrm{CH}_{4}$ budget is still characterised by high uncertainty (Saunois et al., 2016), especially for the tropics (Valentini et al., 2014). The widely differing $\mathrm{CH}_{4}$ estimates between bottom-up models and top-down approaches highlights the considerable uncertainty regarding the relative contributions of individual sources and sinks of $\mathrm{CH}_{4}$ (IPCC, 2013). There is increasing evidence from the last decade pointing to significant tree stem $\mathrm{CH}_{4}$ emissions from wetland and upland (well-drained) forests (Barba et al., 2019a; Covey \& Megonigal, 2019). Yet, estimates of $\mathrm{CH}_{4}$ budget from terrestrial ecosystems are still restricted to net fluxes from soils only (Kirschke et al., 2013; Saunois et al., 2016).

The variation and magnitude of stem $\mathrm{CH}_{4}$ emissions may depend on the tree species, age, site characteristics and environmental conditions (Barba et al., 2019a; Covey \& Megonigal, 2019). Stem emitted $\mathrm{CH}_{4}$ could be produced within the heartwood of trees by methanogenic archaea populations (Covey et al., 2012; Wang et al., 2016, 2017; Pitz \& Megonigal, 2017; Yip et al., 2019), or could originate from soil-produced $\mathrm{CH}_{4}$ under anoxic conditions by methanogens (Pitz \& Megonigal, 2017; Barba et al., 2019b; Welch et al., 2019). The vast majority of tree GHG emission studies have been conducted in tropical wetland forests, where trees have adapted by developing specialist tissues such as lenticels and aerenchyma tissue to facilitate the transport of atmospheric oxygen to anoxic soil layers (Pangala et al., 2014). These aerenchyma tissue have also been related to the transport of dissolved $\mathrm{CH}_{4}$ from the soil through the tree, followed by diffusion through the stem surface to 
the atmosphere largely through the lenticels (Pangala et al., 2013, 2017). However, recent studies have observed tree stem $\mathrm{CH}_{4}$ emissions in well-drained forests where soils predominantly acts as $\mathrm{CH}_{4}$ sinks (Warner et al., 2017; Pitz et al., 2018; Barba et al., 2019b; Welch et al., 2019). Here, trees typically lack aerenchyma tissue, and hence, stem $\mathrm{CH}_{4}$ emissions may originate from root uptake of dissolved $\mathrm{CH}_{4}$ produced in deep anoxic soil layers or methanogenic microsites (von Fischer \& Hedin, 2007; Brewer et al., 2018).

Plant-mediated $\mathrm{CH}_{4}$ fluxes have been found to be significant at the ecosystem level; tree stem fluxes accounted for $62-87 \%$ of the total ecosystem $\mathrm{CH}_{4}$ flux in a tropical forested peatland in Panama (Pangala et al., 2013), and accounts for half of the $\mathrm{CH}_{4}$ emission in the Amazonian floodplain (Pangala et al., 2017). Presently, most tropical forests grow on welldrained soils that tend to act as significant sinks for atmospheric $\mathrm{CH}_{4}$ (Kiese et al., 2003). Dutaur \& Verchot (2007) estimated that about $28 \%$ of the global $\mathrm{CH}_{4}$ sink occur in tropical soils. However, it is possible that even minor $\mathrm{CH}_{4}$ emissions from tree stems could extrapolate to large fluxes globally, which may be significant enough to alter the sink strength of tropical forests, consequently influencing global $\mathrm{CH}_{4}$ budgets. Indeed, previous studies have shown that emissions from tree stems could reduce the $\mathrm{CH}_{4}$ sink of well-drained forests (Pitz \& Megonigal, 2017). This emphasizes the need for further research on the sources, temporal and spatial patterns and magnitudes of tree stem $\mathrm{CH}_{4}$ fluxes in tropical forests. To date, only one study has been published on tree stem $\mathrm{CH}_{4}$ emissions from tropical forests on well-drained soils, and this was conducted in Panama. All tree stem bases in this study emitted significant $\mathrm{CH}_{4}$, in contrast to soil $\mathrm{CH}_{4}$ uptake and emissions in the dry and wet season, respectively. However, until now, the relative contribution of tree to total (soil + stem) $\mathrm{CH}_{4}$ fluxes from lowland tropical forests on well-drained soils remains unknown.

Tropical soils are the largest natural source of atmospheric $\mathrm{CO}_{2}$, contributing $c a .64 \%$ of the estimated global mean soil respiration of about $91 \mathrm{Pg} \mathrm{C} \mathrm{yr}^{-1}$ (Hashimoto et al., 2015). 
Soil $\mathrm{CO}_{2}$ efflux at the soil surface results from the combined activity of autotrophic (root) and heterotrophic (soil fauna and microbial communities) respiration processes (Luo \& Zhou, 2006). Soil $\mathrm{CO}_{2}$ fluxes are temporarily influenced by soil moisture and temperature (Werner $e t$ al., 2007; Wanyama et al., 2019). Spatial differences in soil $\mathrm{CO}_{2}$ fluxes are driven by changes in soil physical and chemical properties (Raich \& Schlesinger, 1998; Luo \& Zhou, 2006), following land-use change most notably the texture of the soil due its strong effect on gas diffusivity within soils (Sotta et al., 2006). Tropical forests also play a significant role in atmospheric $\mathrm{CH}_{4}$ production and uptake (Keller \& Matson, 1994), with well-drained soils constituting the largest biogenic sink of atmospheric $\mathrm{CH}_{4}$ (Dutaur \& Verchot, 2007). Soil $\mathrm{CH}_{4}$ fluxes results from the simultaneous activities of methanogens $\left(\mathrm{CH}_{4}\right.$ producers $)$ under anaerobic conditions and methanotrophs $\left(\mathrm{CH}_{4}\right.$ consumers $)$ in aerobic soil conditions. For well-drained soils such as in our sites, $\mathrm{CH}_{4}$ oxidation by methanotrophic bacteria exceeds $\mathrm{CH}_{4}$ production, resulting in net $\mathrm{CH}_{4}$ sink. Soil $\mathrm{CH}_{4}$ fluxes are primarily controlled by soil moisture and soil texture, with the most important distal regulators been soil fertility and microbial activity (Veldkamp et al., 2013; Hassler et al., 2015). Presently, Africa remains the continent with the lowest numbers of published field studies on soil trace GHG fluxes from the tropical forest biome. Consequently, field studies covering sufficiently large spatial and temporal scales remains key to improving the sink-source estimates of these GHG for this important region (Valentini et al., 2014; Kim et al., 2016b).

Relatively well preserved, the high level of species endemism makes the Congo Basin an important repository of biodiversity and other ecosystem services, supporting the livelihood of 60 million people (de Wasseige et al., 2014). However, conversion of natural forests to agricultural lands such as traditional cacao agroforestry is widespread in the Congo Basin countries, most notably in Cameroon (Sonwa et al., 2007). These cacao farms are typically hand-planted under the shade of forests' remnant trees, and are extensively managed by 
mechanical weeding and no fertilizer inputs. Nevertheless, changes in land use have been found to affect soil $\mathrm{CO}_{2}$ and $\mathrm{CH}_{4}$ fluxes due to changes in soil texture, soil bulk density, soil water content and management practices such as $\mathrm{N}$-fertilization of agricultural lands (Veldkamp et al., 2008, 2013; Hassler et al., 2015). Despite the availability of data on trace soil GHG fluxes from other parts of the world, very little is known about the effect of land-use change on $\mathrm{CH}_{4}$ and $\mathrm{CO}_{2}$ fluxes in African ecosystems.

Given these knowledge gaps, our study provides the first spatially replicated quantification with a full year of measurements of stem and soil $\mathrm{CH}_{4}$ fluxes and soil $\mathrm{CO}_{2}$ fluxes in the Congo Basin, and contributes to the much-needed information on GHG budget from these important ecosystems. Our objectives were to (i) assess whether trees in tropical rainforests and $\mathrm{CAF}$ are important conduits of $\mathrm{CH}_{4}$, (ii) quantify changes in soil-atmosphere fluxes of $\mathrm{CH}_{4}$ and $\mathrm{CO}_{2}$ fluxes with land-use change, and (iii) determine the temporal and spatial controls of stem and soil $\mathrm{CH}_{4}$ and $\mathrm{CO}_{2}$ fluxes. Stem and soil GHG fluxes were measured in the reference forest and the converted CAF at monthly intervals from May 2017 to April 2018. We hypothesized that (i) stem and soil $\mathrm{CH}_{4}$ and $\mathrm{CO}_{2}$ fluxes from extensively managed $\mathrm{CAF}$ systems (unfertilized and manual harvest) will be comparable to the natural forests, and (ii) trees in tropical forests and cacao trees in cacao agroforestry will emit $\mathrm{CH}_{4}$ from stems.

\subsection{Materials and methods}

\subsubsection{Study area and experimental design}

Stem and soil GHG fluxes were measured at three study sites (Tomba, Biba Yezoum and Aloum; Fig. 1.1) located in south and central regions of Cameroon, where conversion of forest to smallholder cacao agroforests is widespread (Sonwa et al., 2007). The study sites have a mean annual temperature of $23.5^{\circ} \mathrm{C}$ (Table S1.1). Rainfall is bimodal, with rainy seasons from March to June and from September to November (Fig. 1.2). The geological substrate of the 
study sites are underlain by Precambrian basement rocks made up of metamorphic schists, phyllites, quartzites and gneiss (Gwanfogbe et al., 1983). The soils are heavily weathered and classified as Ferralsols (IUSS Working Group WRB, 2015).

We investigated two land-use types in each site: the reference forest and the converted CAF system. The cacao farms typically occurred in continuous clusters surrounded by mosaics of secondary forest and cash crop farms, and were hand-planted under the shade of a few remnant forest trees that were selectively retained by farmers during forest clearing. On average, each cacao agroforest had a size of about 0.95 ha (with a range of $0.3-2.5$ ha). Interviews with farmers revealed that localised weeding was done using hand tools, and none of the studied cacao farms have been fertilised. A more detailed description of the study sites and experimental design is reported in Chapter 2.3.

For each of the two land-use types per site, we selected four replicate plots; each replicate plot was $50 \mathrm{~m} \times 50 \mathrm{~m}$ with a minimum distance of $100 \mathrm{~m}$ between plots (Fig. 1.1). Within each plot, we identified and measured the diameter at breast height (DBH) and height of all stems including cacao trees with a $\mathrm{DBH} \geq 10 \mathrm{~cm}$. Stem and soil trace gas fluxes and all associated measurements were then conducted within a $40 \mathrm{~m} \times 40 \mathrm{~m}$ core zone in each plot in order to minimise edge effects.

We assessed the effects of land-use change on stem and soil trace GHG fluxes by first testing the implicit assumption that the initial conditions between the forest and cacao agroforests were similar prior to forest conversion. To do this, we compared the clay contents in 30-50 cm depth between the forest and cacao agroforests within each site. There was no difference in clay contents between the two land uses in each site (Table 2.1), which suggest that both land uses in each site had comparable initial soil conditions prior to conversion. Therefore, any measured differences in GHG fluxes can be attributed solely to land-use change. 
Such as described in Chapter 2.3 above, we measured stem $\mathrm{CH}_{4}$ fluxes by selecting six cacao trees per replicate plot in the cacao agroforests, and six trees of the most dominant species within each replicate plot in the forest, based on their importance value index (IVI) (Table S1.1). For each of the six selected trees per plot, we measured stem $\mathrm{CH}_{4}$ fluxes at $1.3 \mathrm{~m}$ height above the ground at monthly interval from May 2017 to April 2018. We also sampled stem fluxes at different heights along the stems of 16 individual trees per land use type in May 2018, in order to assess the influence of tree height on stem $\mathrm{CH}_{4}$ fluxes. Stem chambers were installed at three different heights $(1.3 \mathrm{~m}, 2.6 \mathrm{~m}$ and $3.9 \mathrm{~m}$ above the ground) per tree in the forest, and at two different heights (1.3 $\mathrm{m}$ and $2.6 \mathrm{~m}$ above the ground) per tree in the cacao agroforests due to the limited height of the cacao trees.

Within each plot, we also installed four permanent chamber bases, which were randomly distributed within the $40 \times 40 \mathrm{~m}$ core zone to measure $\mathrm{CH}_{4}$ and $\mathrm{CO}_{2}$ fluxes from the soil surface. Additionally, we permanently installed a stainless steel soil gas sampler (1-mm internal diameter) located $\sim 1 \mathrm{~m}$ from the measured trees in each replicate plot to measure soil-air $\mathrm{CH}_{4}$ concentrations at $50 \mathrm{~cm}$ below the soil surface. Stem and soil $\mathrm{CH}_{4}$ fluxes and soil $\mathrm{CO}_{2}$ fluxes were measured monthly from May 2017 to April 2018, together with meteorological and soil variables.

\subsubsection{Measurement of stem and soil $\mathrm{CH}_{4}$ fluxes and soil $\mathrm{CO}_{2}$ fluxes}

Stem $\mathrm{CH}_{4}$ fluxes were measured using stem chambers made of polyethylene-terephthalate foil (same method as described in Chapter 2.3.2). One month prior to the measurement, we prepared trees for stem chamber installation by applying permanent strips of silicone (Otto Seal ® S110, Hermann Otto GmbH, Fridolfing, Germany) around the stem of each tree, $20 \mathrm{~cm}$ apart, with the center of the two strips at a height between $1.2 \mathrm{~m}$ and $1.4 \mathrm{~m}$ from the ground. The installation of these stem chambers is quick, hence, new chambers were installed to the stems on every 
measurement date rather than installing them permanently. The permanent silicone strips were used as a mark to ensure that the same 20 -cm length stem section was sampled. A Luer-lock sampling port was fixed onto the foil, which was then wrapped around the tree stem on top of the silicone strips, and the vertical ends of the foil taped together to form a chamber around the stem. The foil was then shrunk to fit closely onto the silicone strips using a heat gun, after which we attached polyethylene foam over the foil above and below the silicone strips. The foams were tightly adjusted over the foil and silicone with lashing straps using ratchet tensioners to ensure an airtight fitting. Using a syringe fitted with a Luer-lock one-way check valve, we completely evacuated the headspace inside the stem chamber, and replaced it with a known volume of ambient air using a manual bicycle pump, to allow for stem $\mathrm{CH}_{4}$ flux calculations. Immediately after stem chamber refilling and closure, a 25-mL gas sample was taken with syringe and stored with overpressure in pre-evacuated 12-mL exetainers (Labco Limited, Lampeter, UK) with rubber septa, and then gain after 20, 40 and 60 minutes.

Soil $\mathrm{CH}_{4}$ and $\mathrm{CO}_{2}$ fluxes were measured simultaneously with stem $\mathrm{CH}_{4}$ fluxes using vented, static chambers (made of polyvinyl chloride pipe with $0.04 \mathrm{~m}^{2}$-area and $\sim 0.02-\mathrm{m}$ insertion into the soil) that were permanently installed in the soil one month prior to the start of trace gas measurements. The chamber bases were covered with vented, static polyethylene hoods (resulting in $11 \mathrm{~L}$ total headspace volume) on each sampling day. From each chamber, samples of the enclosed headspace were taken four times over a 32-minute closure period: $t_{0}$ at 2 minutes after closure and three samples thereafter at 10-minute interval. The gas samples were taken using a $25-\mathrm{mL}$ syringe and immediately stored with overpressure in pre-evacuated 12-mL exetainers.

On the same day, soil-air $\mathrm{CH}_{4}$ concentrations were sampled from the permanently installed stainless steel sampling probes by fitting the probes with Luer-lock sampling ports. Using a syringe, we first removed and discarded the top 5-mL of air to clear the probes of 
"dead" air volume, after which we took $25 \mathrm{~mL}$ gas samples and stored them in $12 \mathrm{~mL}$ preevacuated exetainers. The exetainers we used have been confirmed to be leak-proof in our previous studies (e.g. Hassler et al., 2015; Matson et al., 2017; van Straaten et al., 2019). All the gas samples were brought to the University of Goettingen, Germany for analysis.

\subsubsection{Trace greenhouse gas analysis and flux rate calculation}

Gas samples were analysed for $\mathrm{CH}_{4}$ and $\mathrm{CO}_{2}$ concentrations using a gas chromatograph (SRI 8610C, SRI Instruments Europe $\mathrm{GmbH}$, Bad Honnef, Germany), equipped with a flame ionization detector (FID), an electron capture detector (ECD) and an autosampler (AS-210, SRI Instruments). Before analysing the gas samples, the gas chromatograph was calibrated with three calibration gases (Deuste Steininger GmbH, Mühlhausen, Germany), taking into the consideration the concentration ranges of our field samples. Stem and soil $\mathrm{CH}_{4}$ and soil $\mathrm{CO}_{2}$ fluxes were calculated from the linear change in headspace concentrations over time of chamber closure, and corrected with air temperature and atmospheric pressure measured in each replicate plot at the time of sampling. Individual chamber measurements were quality checked using the linear increase in $\mathrm{CO}_{2}$ concentration with time. In a small number of cases where $\mathrm{CO}_{2}$ concentration curved at a particular point, we excluded the data point and calculated the fluxes based on the remaining three sampling data points that showed a linearity of increase in $\mathrm{CO}_{2}$ concentrations with time $\left(R^{2}>0.9\right)$. Nonetheless, our data analyses included zero and negative fluxes in order to avoid overestimation of stem and soil fluxes.

We calculated annual stem and soil $\mathrm{CH}_{4}$ and $\mathrm{CO}_{2}$ fluxes following the same extrapolation method described in Chapter 2.3.3 (pg. 32) above. The annual $\mathrm{CH}_{4}$ fluxes from each replicate plot, expressed on a hectare basis, were represented by the sum of the stem and soil $\mathrm{CH}_{4}$ fluxes. 


\subsubsection{Soil and climatic variables}

Concurrent with stem and soil trace gas flux measurements, we determined soil and air temperature, moisture and mineral $\mathrm{N}$ concentrations from the top $0.05 \mathrm{~m}$ of soil near the chamber bases on each sampling day. Soil and air temperature were measured close to the stem and soil chambers using a digital thermometer (GTH 175, Greisinger electronic GmbH, Regenstauf, Germany). Soil moisture and mineral N concentrations were determined from a composite sample that were pooled from four sampling locations $\sim 1 \mathrm{~m}$ away from the chamber bases per replicate plot on each sampling day. Some of the soil subsample were oven-dried at $105^{\circ} \mathrm{C}$ for $24 \mathrm{~h}$ to determine the gravimetric moisture content, and then converted to soil waterfilled pore space (WFPS) using the mineral soil particle density of $2.65 \mathrm{~g} \mathrm{~cm}^{-3}$ and the average soil bulk densities from each plot (Table 2.1). Soil mineral N concentrations were extracted insitu in the field by adding some of the composite soil samples to already prepared bottles filled with $150 \mathrm{~mL}$ solution of $0.5 \mathrm{M} \mathrm{K}_{2} \mathrm{SO}_{4}$ and shaken thoroughly. The mineral $\mathrm{N}$ samples were shaken for an hour and filtered through $\mathrm{K}_{2} \mathrm{SO}_{4}$ pre-washed filter papers upon arrival at the field station. The filtered extracts were then stored in $20 \mathrm{~mL}$ scintillation vials and immediately frozen for transport by air to the University of Goettingen, Germany, where they were analysed for $\mathrm{NH}_{4}{ }^{+}$and $\mathrm{NO}_{3}{ }^{-}$concentrations using continuous flow injection colorimetry (SEAL Analytical AA3, SEAL Analytical GmbH, Norderstedt, Germany).

We also recorded the relative humidity, air temperature and solar irradiance of each plot over the course of each sampling day using a portable weather station. From this data, we calculated vapour pressure deficit (VPD) using measured air temperature and relative humidity (Allen et al., 1998).

In April 2017, we conducted a one-time soil sampling at three depth intervals down to $50 \mathrm{~cm}$ to determine the soil biochemical characteristics. To capture the spatial variability in 
each replicate plot, soil samples were collected from ten randomly selected sampling points per plot from the top $0-0.1 \mathrm{~m}$ depth, and five samples each from $0.1-0.3$ and $0.3-0.5 \mathrm{~m}$ depths. In total, 480 soil samples were collected from the 24 plots (three sites $\times$ two land uses $\times$ four replicate plots $\times 20$ soil samples per plot). The soil samples were air-dried, 2-mm sieved, transported by air to Germany and dried again at $40{ }^{\circ} \mathrm{C}$ prior to analysis in the laboratory. Soil $\mathrm{pH}$ was analysed from a 1:2.5 soil-to-distilled water ratio. We determined the soil texture of each replicate plot using the pipette method after iron oxide and organic matter removal (Kroetsch \& Wang, 2008). The effective cation exchange capacity (ECEC) was determined from the soil samples by percolating with unbuffered $1 \mathrm{M} \mathrm{NH} 4 \mathrm{Cl}$ and measuring the exchangeable element concentrations ( $\mathrm{Al}, \mathrm{Ca}, \mathrm{Fe}, \mathrm{K}, \mathrm{Mg}, \mathrm{Mn}$, and $\mathrm{Na}$ ) in the percolates using an inductively coupled plasma-atomic emission spectrometer (ICP-AES; iCAP 6300 Duo VIEW ICP Spectrometer, Thermo Fischer Scientific GmbH, Dreieich, Germany). Base and Al saturations were calculated, respectively, as the percent exchangeable bases $(\mathrm{Mg}, \mathrm{Ca}, \mathrm{K}$ and $\mathrm{Na}$ ) and $\mathrm{Al}$ of the ECEC. Grounded soil and litter samples were used to analyse for total N, total organic C (using a CN analyser; Vario EL Cube; Elementar Analysis Systems GmbH, Hanau, Germany) and ${ }^{15} \mathrm{~N}$ natural abundance signatures (using isotope ratio mass spectrometry; Delta Plus; Finnigan MAT, Bremen, Germany). Soil organic C and total N of the cacao agroforestry were calculated using the bulk densities of the forest, to avoid overestimation of stocks resulting from increases in bulk densities due to land-use change.

\subsubsection{Statistical analysis}

Statistical tests of stem and soil $\mathrm{CH}_{4}$ and $\mathrm{CO}_{2}$ gas fluxes were based on the average of the six trees and of the four chambers that represent each replicate plot on a given sampling day. We first checked the data for normality using Shapiro-Wilk's test, and those exhibiting non-normal distributions were log- or square root-transformed. Linear mixed-effect models (LMEs) were used to assess the differences in stem and soil $\mathrm{CH}_{4}$ and $\mathrm{CO}_{2}$ fluxes and accompanying soil 
factors (soil temperature, WFPS and mineral N concentrations) between the two land-use types for each site, and among the three sites for each land-use type. When applying LMEs, land-use (when comparing land-use types within each site) and site (when comparing sites for each landuse type) were used as fixed effects in the model, and replicate plots and sampling days as random effects. Differences between the land uses per site or among sites per land-use type were assessed using analysis of variance (ANOVA) with Fisher's least significant difference (LSD) test.

Additionally, stem $\mathrm{CH}_{4}$ emissions were tested for differences among tree species across the four forest plots at each site as well as across the three sites for the forest land use using LME. Here, tree species were used as fixed effect in the model, and the random effects were trees belonging to each species and sampling days.

We used one-way ANOVA with Fisher's LSD test to test for differences in soil biochemical and litter characteristics between the two land uses at each site, and among sites for each land-use type, when the parameter exhibits a normal distribution and homogenous variance. Kruskal-Wallis ANOVA with multiple comparison extension test was applied when assumptions of normality and variance homogeneity were not met.

Using the means of the four replicate plots for each land-use type per site, we determined the temporal controls of stem and soil trace gas fluxes by testing their correlations with the soil controlling factors using the Spearman correlation test. The correlations were conducted separately for each land-use type across the three sites and sampling days $(n=33(3$ sites $\times 11$ monthly measurements)). Spatial controls of stem and soil annual trace gas fluxes were determined by assessing their relationship with soil biochemical characteristics, conducted across land uses and sites $(n=24$ ( 3 sites $\times 2$ land uses $\times 4$ replicate plots $))$. The statistical 
significance for all the tests were set at $p \leq 0.05$. Data analysis were performed using the $\mathrm{R}$ (version 3.5.2) open source software (R Core Team, 2018).

\subsection{Results}

\subsubsection{Stem $\mathrm{CH}_{4}$ fluxes}

All the studied trees emitted measureable $\mathrm{CH}_{4}$ at some point during the measurement period (Fig. 3.1). Stem $\mathrm{CH}_{4}$ fluxes neither differed between the forest and cacao agroforestry at each site $(p=0.12-0.71$; Table 3.1), nor among the three sites for each land use type $(p=0.24-0.43$; Table 3.1).
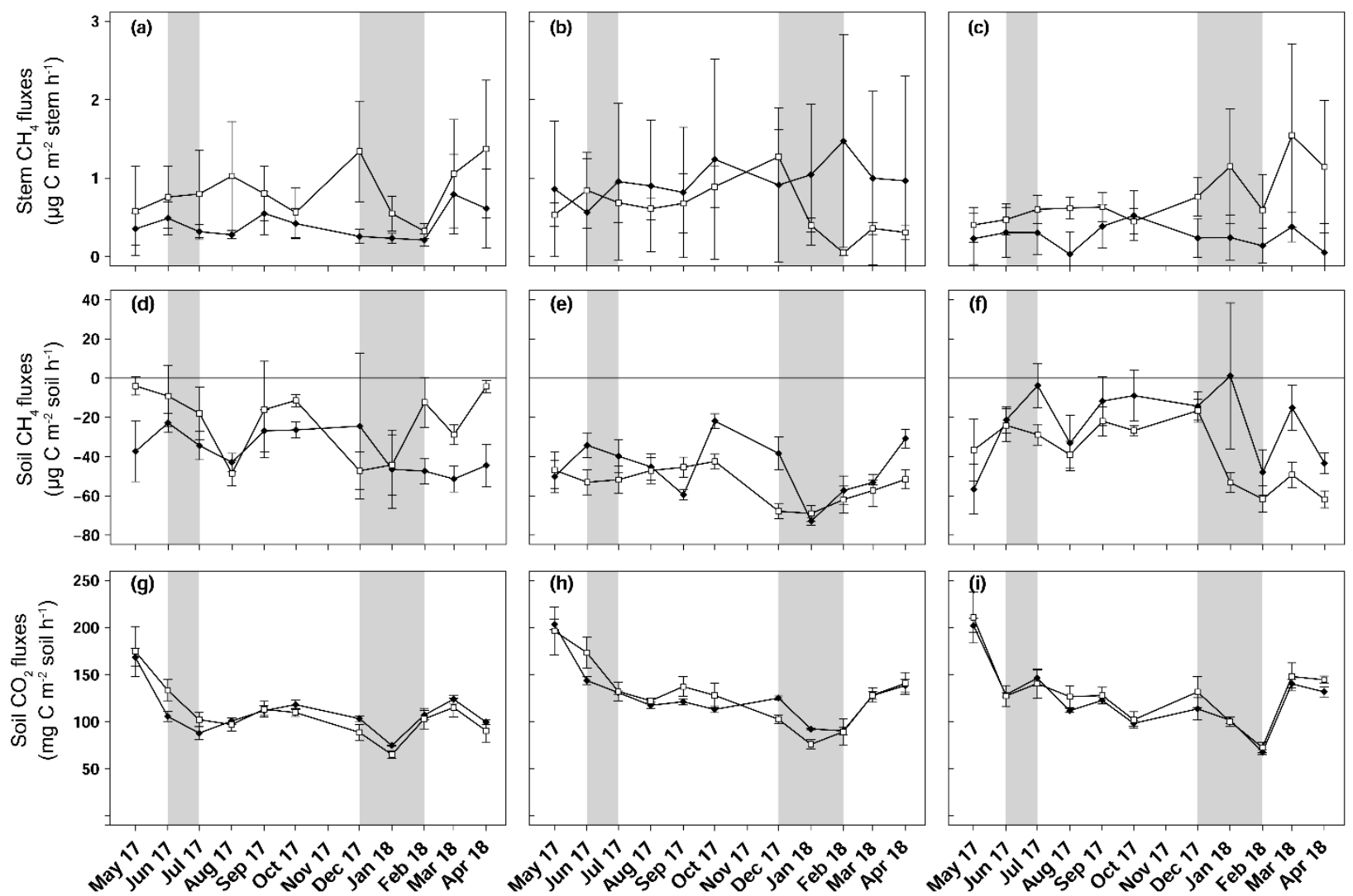

Figure 3.1. Mean $( \pm \mathrm{SE}, \mathrm{n}=4)$ stem $\mathrm{CH}_{4}$ fluxes (top panel), soil $\mathrm{CH}_{4}$ fluxes (middle panel) and soil $\mathrm{CO}_{2}$ fluxes in Aloum site (a, $\mathrm{d}$ and $\left.\mathrm{g}\right)$, Biba Yezoum site (b, e and h) and Tomba site (c, $\mathrm{f}$ and i) on highly weathered soils in the Congo Basin, Cameroon, measured monthly from May 2017 to April 2018. Forest ( $\downarrow$ ) and cacao agroforestry ( $\square$ ); grey shadings mark the dry season. 
We did not also detect any differences in stem $\mathrm{CH}_{4}$ fluxes between the wet season and the dry season for both land uses ( $p=0.55-0.80$; Fig. 3.1, Tables S3.1 and S3.2). Additionally, stem $\mathrm{CH}_{4}$ emissions did not vary among tree species in forest plots at each site as well as across the three sites ( $p=0.13-0.83$; Fig. 3.2), nor among tree diameter sizes $(p=0.38-0.51)$.

Table 3.1. Mean $( \pm \mathrm{SE}, n=4)$ stem $\mathrm{CH}_{4}$ emission, soil $\mathrm{CH}_{4}$ uptake and soil $\mathrm{CO}_{2}$ emissions from forest and cacao agroforestry system within each site in the Congo Basin, Cameroon. Means followed by different lowercase letters indicate significant differences between land-use types within each site and different capital letters indicate significant differences among the three sites within a land-use type (linear mixed-effect models with Tukey's HSD at $p \leq 0.05$ ).

\begin{tabular}{llll}
\hline Site/Land-use type & $\begin{array}{l}\text { Stem } \mathrm{CH}_{4} \text { fluxes } \\
\left(\mu \mathrm{g} \mathrm{C} \mathrm{m} \mathrm{m}^{-2} \mathrm{stem}\right. \\
\left.\mathrm{h}^{-1}\right)\end{array}$ & $\begin{array}{l}\text { Soil } \mathrm{CH}_{4} \text { fluxes } \\
\left(\mu \mathrm{g} \mathrm{m}^{-2} \mathrm{~h}^{-1}\right)\end{array}$ & $\begin{array}{l}\mathrm{Soil} \mathrm{CO}_{2} \text { fluxes } \\
\left(\mathrm{mg} \mathrm{C} \mathrm{m}^{-2} \mathrm{~h}^{-1}\right)\end{array}$ \\
\hline Aloum & $0.41 \pm 0.07^{\mathrm{a}, \mathrm{A}}$ & $-36.8 \pm 4.2^{\mathrm{a}, \mathrm{A}}$ & $109.1 \pm 4.1^{\mathrm{a}, \mathrm{A}}$ \\
\hline Forest & $0.83 \pm 0.15^{\mathrm{a}, \mathrm{A}}$ & $-22.2 \pm 4.1^{\mathrm{a}, \mathrm{B}}$ & $108.3 \pm 5.1^{\mathrm{a}, \mathrm{A}}$ \\
Cacao & & & \\
\hline Biba Yezoum & $0.98 \pm 0.28^{\mathrm{a}, \mathrm{A}}$ & $-45.8 \pm 2.7^{\mathrm{a}, \mathrm{A}}$ & $127.5 \pm 4.7^{\mathrm{a}, \mathrm{A}}$ \\
\hline Forest & $0.60 \pm 0.08^{\mathrm{a}, \mathrm{A}}$ & $-54.0 \pm 2.1^{\mathrm{a}, \mathrm{A}}$ & $129.6 \pm 6.1^{\mathrm{a}, \mathrm{A}}$ \\
Cacao & & & \\
\hline Tomba & & $-23.2 \pm 4.9^{\mathrm{a}, \mathrm{A}}$ & $124.0 \pm 5.6^{\mathrm{a}, \mathrm{A}}$ \\
\hline Forest & $0.26 \pm 0.08^{\mathrm{a}, \mathrm{A}}$ & $-38.2 \pm 3.1^{\mathrm{a}, \mathrm{AB}}$ & $130.1 \pm 6.2^{\mathrm{a}, \mathrm{A}}$ \\
Cacao & $0.76 \pm 0.15^{\mathrm{a}, \mathrm{A}}$ & & \\
\hline
\end{tabular}



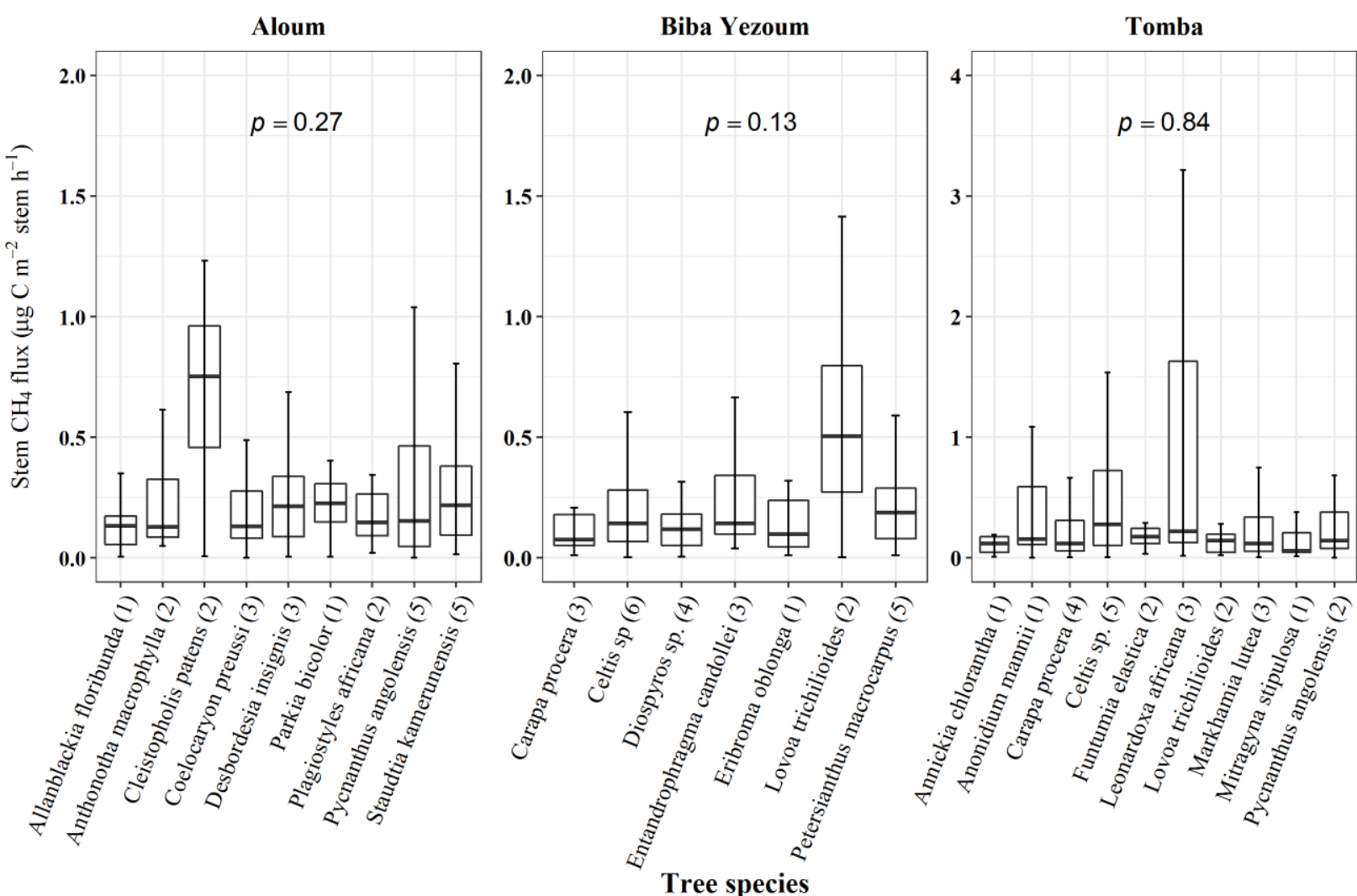

Tree species

Figure 3.2. Stem $\mathrm{CH}_{4}$ fluxes from 22 tree species at three forest sites (Aloum, Biba Yezoum and Tomba) across central and south Cameroon in the Congo Basin. Boxes $\left(25^{\text {th }}\right.$, median and $75^{\text {th }}$ percentile $)$ and whiskers $(1.5 \times$ interquartile range $)$ are based on $\mathrm{CH}_{4}$ fluxes measured monthly from May 2017 to April 2018 for each tree species, and the values in parentheses represent the number of trees measured per species. There were no differences in $\mathrm{CH}_{4}$ fluxes among species (linear mixed-effect models with Tukey's HSD at $p>0.13$ ).

Stem $\mathrm{CH}_{4}$ emissions decreased with increasing stem height in both land uses (Fig. 3.3). Using the upscaling method described in the Materials and Methods section (see Chapter 2.3.3 above), the mean annual stem $\mathrm{CH}_{4}$ fluxes were $0.33 \pm 0.06 \mathrm{~kg} \mathrm{C} \mathrm{ha}^{-1} \mathrm{yr}^{-1}$ for the forest and 0.20 $\pm 0.03 \mathrm{~kg} \mathrm{C} \mathrm{ha}^{-1} \mathrm{yr}^{-1}$ for the cacao agroforestry, when including the shade trees in the cacao plots. This was equivalent to $c a$. $5-18 \%$ and $3-14 \%$ of the amount of $\mathrm{CH}_{4}$ consumed by the soils in the forest and cacao agroforestry, respectively. 


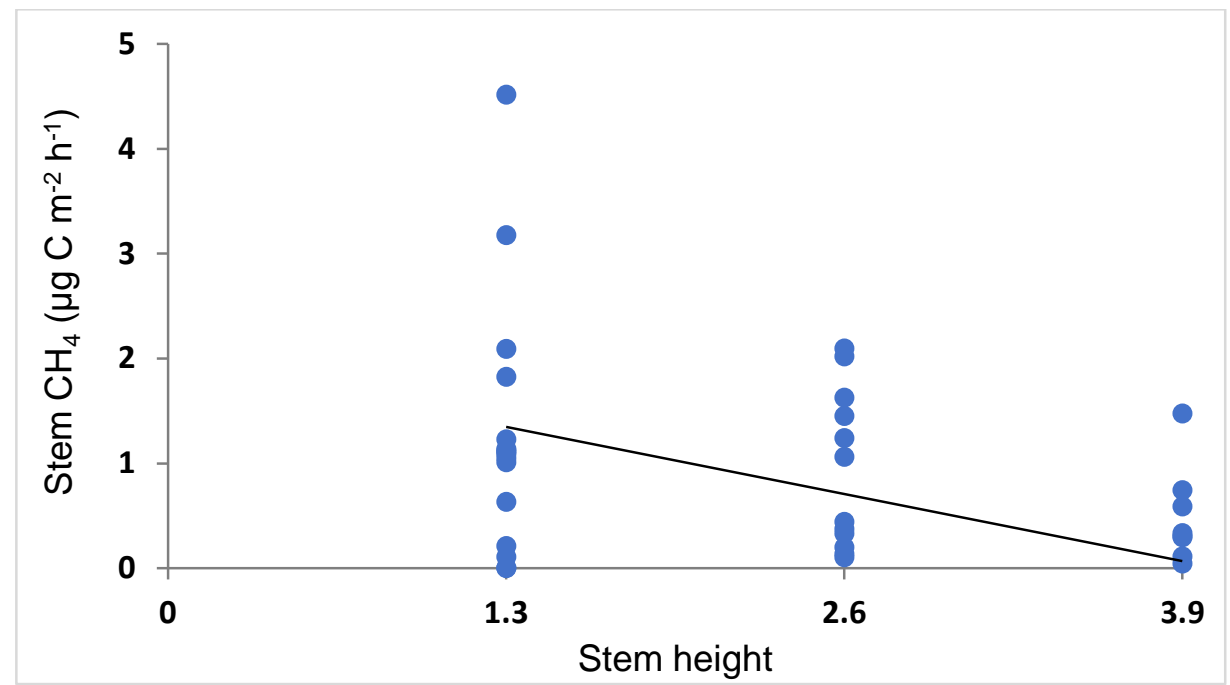

Figure 3.3. Mean $(n=16)$ stem $\mathrm{CH}_{4}$ emissions at three different heights along the tree stem on highly weathered soils in the Congo Basin, Cameroon.

Table 3.2. Annual trace gas fluxes (mean \pm SE, $n=4$ ) from lowland rainforest and cacao agroforestry system within each site on highly weathered soils in the Congo Basin, Cameroon. Annual fluxes were not statistically tested for differences among sites or between land-use types since these annual values are trapezoidal extrapolations.

\begin{tabular}{|c|c|c|c|c|}
\hline $\begin{array}{l}\text { Site/ Land-use } \\
\text { type }\end{array}$ & $\begin{array}{l}\text { Annual stem } \\
\mathrm{CH}_{4} \text { fluxes } \\
\left(\mathrm{Kg} \mathrm{C} \mathrm{ha}^{-1} \mathrm{yr}^{-1}\right)\end{array}$ & $\begin{array}{l}\text { Annual soil } \mathrm{CH}_{4} \\
\text { fluxes } \\
\left(\mathrm{Kg} \mathrm{C} \mathrm{ha}^{-1} \mathrm{yr}^{-1}\right)\end{array}$ & $\begin{array}{l}\text { Total (soil + } \\
\text { stem) } \mathrm{CH}_{4} \mathrm{flu} \\
\left(\mathrm{Kg} \mathrm{C} \mathrm{ha}^{-1} \mathrm{yr}^{-1}\right)\end{array}$ & $\begin{array}{l}\text { Annual soil } \mathrm{CO}_{2} \\
\text { fluxes } \\
\left(\mathrm{Mg} \mathrm{C} \mathrm{ha}^{-1} \mathrm{yr}^{-1}\right)\end{array}$ \\
\hline \multicolumn{5}{|l|}{ Aloum } \\
\hline Forest & $0.56 \pm 0.02$ & $-3.16 \pm 0.52$ & $-2.60 \pm 0.59$ & $10.24 \pm 0.45$ \\
\hline Cacao & $\begin{array}{l}0.31 \pm 0.05 \\
(0.04 \pm 0.01)\end{array}$ & $-2.16 \pm 0.72$ & $-1.85 \pm 0.80$ & $10.78 \pm 0.65$ \\
\hline \multicolumn{5}{|l|}{ Biba Yezoum } \\
\hline Forest & $0.35 \pm 0.02$ & $-3.98 \pm 0.27$ & $-3.62 \pm 0.33$ & $10.71 \pm 0.16$ \\
\hline Cacao & $\begin{array}{l}0.17 \pm 0.02 \\
(0.02 \pm 0.00)\end{array}$ & $-4.80 \pm 0.34$ & $-4.62 \pm 0.40$ & $10.87 \pm 0.56$ \\
\hline \multicolumn{5}{|l|}{ Tomba } \\
\hline Forest & $0.08 \pm 0.00$ & $-1.72 \pm 0.55$ & $-1.64 \pm 0.64$ & $9.30 \pm 0.42$ \\
\hline Cacao & $\begin{array}{l}0.10 \pm 0.01 \\
(0.06 \pm 0.02)\end{array}$ & $-3.31 \pm 0.33$ & $-3.20 \pm 0.39$ & $9.13 \pm 0.58$ \\
\hline
\end{tabular}

Note. Annual stem and soil $\mathrm{CH}_{4}$ and $\mathrm{CO}_{2}$ fluxes were not statistically tested for differences among sites or between land-use types since these annual values are trapezoidal extrapolations (see section 2.3.3). Annual stem $\mathrm{CH}_{4}$ emissions in parentheses are from cacao trees only. 
Three individual trees from the forest and one tree from the cacao agroforestry consistently emitted high $\mathrm{CH}_{4}$ throughout the study period, with stem $\mathrm{CH}_{4}$ fluxes ranging from 4.9 to $154.8 \mu \mathrm{g} \mathrm{C} \mathrm{m}^{-2} \mathrm{~h}^{-1}$ in the forest and 6.1 to $68.6 \mu \mathrm{g} \mathrm{C} \mathrm{m}^{-2} \mathrm{~h}^{-1}$ in the cacao agroforestry (Fig. 3.4). When including these trees in the annual flux calculations, the balance between the soil and stem $\mathrm{CH}_{4}$ fluxes indicated that the replicate plots containing these high emitting trees could be net $\mathrm{CH}_{4}$ sources.

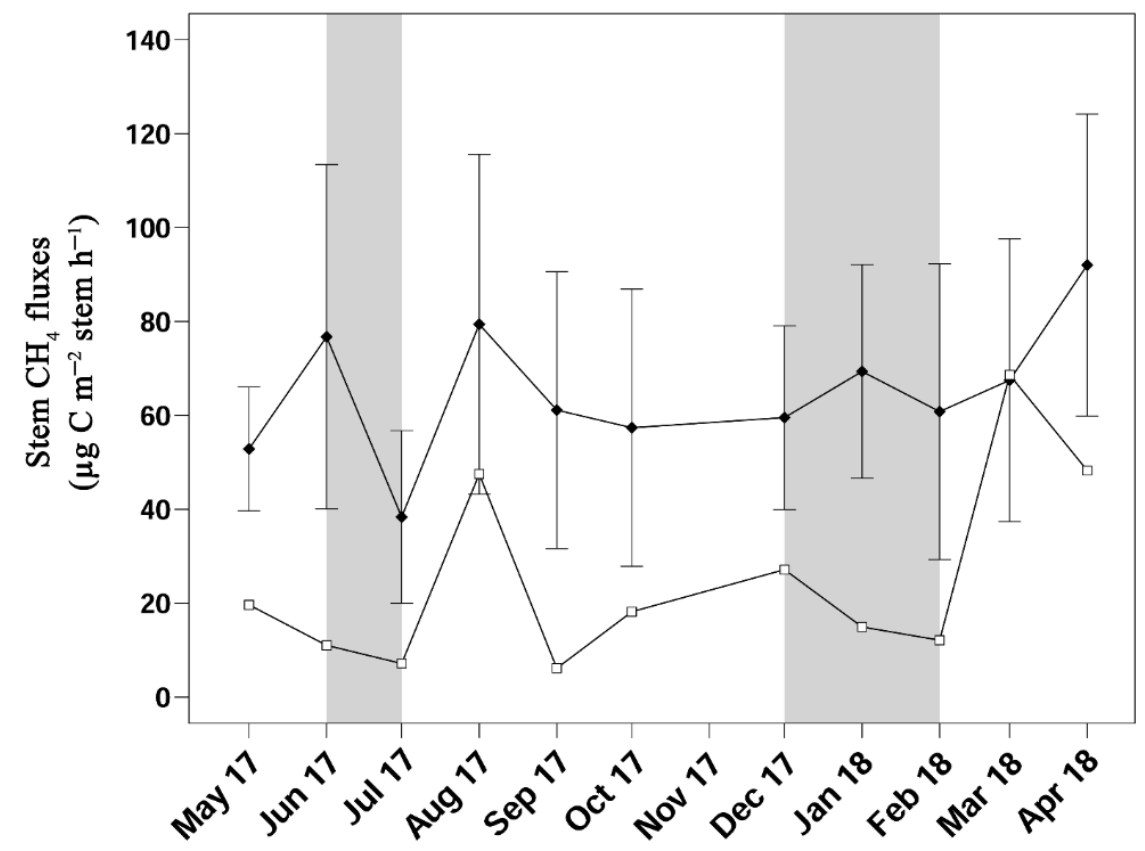

Figure 3.4. Mean stem $\mathrm{CH}_{4}$ emissions on highly weathered soils in the Congo Basin, Cameroon, measured monthly from May 2017 to April 2018. Stem values are average of three trees for the forest $(\triangleleft)$ and one tree for the cacao agroforestry ( $\square$ ); grey shadings mark the dry season.

Across the study period, average stem $\mathrm{CH}_{4}$ emissions from the forest were positively correlated with average WFPS (Spearman $\rho=0.37, p<0.05, n=33$ ), while in the cacao agroforestry, we found positive correlations of stem $\mathrm{CH}_{4}$ emissions with soil-air $\mathrm{CH}_{4}$ concentration across sampling dates $(\rho=0.35, p<0.05, n=33)$. 


\subsubsection{Soil $\mathrm{CH}_{4}$ fluxes}

Soil $\mathrm{CH}_{4}$ fluxes were comparable between the forest and cacao agroforestry at each site $(p=$ 0.20-0.89; Table 3.1). In the cacao agroforestry, soil $\mathrm{CH}_{4}$ uptake was higher at Biba Yezoum than at the Aloum site $\left(p<0.01\right.$; Table 3.1), but, in the forest, Soil $\mathrm{CH}_{4}$ fluxes did not differ across sites ( $p=0.32$; Table 3.1). When compared between seasons, soil $\mathrm{CH}_{4}$ uptake was higher in the dry season than in the wet season at Aloum for the cacao agroforestry system $(p=0.05$; Fig. 3.1, Table S2). However, we did not detect any seasonal differences among the study sites in the forest $\left(p=0.14-0.92\right.$; Fig. 3.1, Table S3). The mean annual soil $\mathrm{CH}_{4}$ uptake was $-2.95 \pm$ $0.38 \mathrm{~kg} \mathrm{C} \mathrm{ha}^{-1} \mathrm{yr}^{-1}$ for the forest and $-3.42 \pm 0.42 \mathrm{~kg} \mathrm{C} \mathrm{ha}^{-1} \mathrm{yr}^{-1}$ for the cacao agroforestry. Thus, the balance between the soil and stem $\mathrm{CH}_{4}$ fluxes indicated that there was a net $\mathrm{CH}_{4}$ sink in both land uses (Table 3.2).

Over the measurement period, moisture was the dominant controlling factor of soil $\mathrm{CH}_{4}$ fluxes, with average monthly soil $\mathrm{CH}_{4}$ fluxes correlating positively with WFPS in both land uses $(\rho=0.45-0.86, p<0.01, n=33)$. Additionally, soil $\mathrm{CH}_{4}$ fluxes from the cacao agroforestry were positively correlated with average soil-air $\mathrm{CH}_{4}$ concentrations $(\rho=0.36, p<0.05, n=33)$, and negatively correlated with soil $\mathrm{NH}_{4}{ }^{+}$content $(\rho=0.42, p<0.05, n=33)$.

Of the soil physical and biochemical characteristics measured once, annual soil $\mathrm{CH}_{4}$ fluxes were correlated positively with clay contents (Spearman $\rho=0.50, p<0.05, n=24$ ) and aluminium saturation $(\rho=0.45, p<0.05, n=24)$.

\subsubsection{Soil $\mathrm{CO}_{2}$ fluxes}

We did not detect any differences in soil $\mathrm{CO}_{2}$ emissions between the forest and cacao agroforestry at each site $(p=0.60-0.95$; Table 3.1$)$, nor among the three study sites for each land use type ( $p=0.14-0.19$; Table 3.1). In both land uses, average soil $\mathrm{CO}_{2}$ emissions were highest at the beginning of our measurement period, which coincided with the end of the rainy 
season (Fig. 3.1). This was followed by a gradual decline in soil $\mathrm{CO}_{2}$ efflux as the soil moisture levels decreased during the dry season. The beginning of the wet season in August stimulated soil $\mathrm{CO}_{2}$ emissions again, but further reductions in soil moisture during the second dry season resulted in decreasing soil $\mathrm{CO}_{2}$ emissions (Fig. 3.1). Accordingly, average soil $\mathrm{CO}_{2}$ emissions showed clear seasonal variability with larger fluxes in the wet season than the dry season for both land uses ( $p<0.05$; Fig. 3.1, Tables S3.1 and S3.2). The mean annual soil $\mathrm{CO}_{2}$ emissions were $10.1 \pm 0.27 \mathrm{Mg} \mathrm{Cha}^{-1} \mathrm{yr}^{-1}$ for the forest, and $10.3 \pm 0.42 \mathrm{Mg} \mathrm{Cha}^{-1} \mathrm{yr}^{-1}$ for the cacao agroforestry.

While soil $\mathrm{CO}_{2}$ fluxes did not correlate with soil WFPS, we did find a parabolic relationship between soil $\mathrm{CO}_{2}$ emissions and soil moisture in both land uses. Across sites and land uses, the only significant correlation between annual soil $\mathrm{CO}_{2}$ emissions and soil physical and biochemical characteristics was with sand content $(\rho=0.45, p<0.05, n=24)$.

\subsection{Discussion}

\subsubsection{Stem $\mathrm{CH}_{4}$ emissions and their contribution to total (soil + stem) $\mathrm{CH}_{4}$ emissions}

To our knowledge, this study provides the first year-round simultaneous measurements of stem and soil $\mathrm{CH}_{4}$ fluxes from tropical Africa. The mean stem $\mathrm{CH}_{4}$ emissions we measured from our sites (Table 3.1) were in the lower range of those reported for temperate and boreal upland (well-drained) forests (0.004-22.6 $\mu \mathrm{g} \mathrm{C} \mathrm{m}^{-2} \mathrm{~h}^{-1}$ (Machacova et al., 2016; Wang et al., 2016; Warner et al., 2017; Maier et al., 2018; Pitz et al., 2018; Barba et al., 2019b; Welch et al., 2019). Our stem $\mathrm{CH}_{4}$ emissions were also significantly lower than those reported for wetland and floodplain ecosystems (42.6-427.0 $\mu \mathrm{g} \mathrm{C} \mathrm{m}^{-2} \mathrm{~h}^{-1}$; Gauci et al., 2010; Pangala et al., 2013, 2015; Terazawa et al., 2015; Pitz et al., 2018). The high stem $\mathrm{CH}_{4}$ emissions in wetlands and floodplains may be characteristic of the equally high soil $\mathrm{CH}_{4}$ concentrations resulting from the dominance of methanogenic activity in the soils of these ecosystems (Terazawa et al., 2007), 
which have been found to be predominantly emitted via plants (Terazawa et al., 2007; Pangala et al., 2013). Additionally, our mean stem emission values were 11-fold lower than the mean stem $\mathrm{CH}_{4}$ emissions reported for Heisteria concinna $\left(75.9 \mu \mathrm{g} \mathrm{C} \mathrm{m}^{-2} \mathrm{~h}^{-1}\right)$ and Simarouba amara $\left(65.9 \mu \mathrm{g} \mathrm{C} \mathrm{m}^{-2} \mathrm{~h}^{-1}\right)$ tree species in a moist tropical forest in Panama (Welch et al., 2019). It is more likely that the results of Welch et al. (2019) may have calculation errors, especially because they were not able to measure any significant stem $\mathrm{CH}_{4}$ emissions during the dry season. Additionally, they consistently measured higher tree-stem than soil fluxes, which has not been shown in any upland study elsewhere. Nevertheless, the wide range of stem emissions reported in the literature signifies the substantial spatial and temporal variability in stem $\mathrm{CH}_{4}$ fluxes, and highlights the complexity in accounting for stem emissions in global GHG budgets.

More recent evidence suggest that differences in tree diameter sizes, age or species (Pangala et al., 2015; Wang et al., 2016; Warner et al., 2017; Pitz et al., 2018; Welch et al., 2019) can significantly influence tree stem emissions, although we could not corroborate these findings in our study (Fig. 3.2). This may possibly be due to the small diameter range of our measured trees (10-18 cm DBH for cacao trees and 10-30 cm DBH for the forest trees). Indeed, Pitz et al. (2018) found a positive correlation between stem $\mathrm{CH}_{4}$ emissions and tree diameter (tree $\mathrm{DBH}$ range from 16 to $93 \mathrm{~cm}$ ). Compared to young, small trees, older and bigger trees are suggested to emit higher $\mathrm{CH}_{4}$ owing to their large, deep tap root system which can tap deep into anoxic soil layers (Pierret et al., 2016; Barba et al., 2019a) or groundwater, which are both potential $\mathrm{CH}_{4}$ sources. It is possible that the different tree species in our study sites utilise similar $\mathrm{CH}_{4}$ transport mechanisms, which may have accounted for the lack of differences in stem emissions among species (Fig. 3.2) and between land uses, supporting our first hypothesis (Table 1). Recent literature reviews (Barba et al., 2019a; Covey \& Megonigal, 2019) show that tree physiology and traits of wood anatomy can influence species-level $\mathrm{CH}_{4}$ emissions; however, these have mostly been demonstrated for wetland species. For example, wood specific 
density and lenticel density have been shown to affect wetland tree stem $\mathrm{CH}_{4}$ fluxes (Pangala et al., 2013, 2014). Evapotranspiration rate and wood density were possibly the reason for the higher stem $\mathrm{CH}_{4}$ emissions of the fast-growing Simarouba compared to the shade-tolerant Heisteria species in an upland tropical forest in Panama (Welch et al., 2019). However, there is still limited knowledge about how tree species traits contribute to stem flux differences in tropical trees. New studies that measures several trees of different species, diameter classes and ages could further our understanding of the spatial variability of stem emissions from ecosystem to regional and global levels.

Our results demonstrate that tropical trees on well drained soils represent potential $\mathrm{CH}_{4}$ emission pathways that have largely been ignored, with stem $\mathrm{CH}_{4}$ emissions constituting a considerable offset of the soil $\mathrm{CH}_{4}$ sink in both forest and cacao agroforestry, supporting our second hypothesis (Table 2). This finding is particularly important considering that trees occupy less than $10 \%$ ground area in the study plots. Tree stem emissions were found to offset $5-18 \%$ of the soil sink in our forest sites, which brackets the range of estimates reported for two upland forests in America (16\%; Pitz \& Megonigal, 2017; Warner et al., 2017). These estimates are lower than those reported for wetland forests, where tree-mediated $\mathrm{CH}_{4}$ emissions were found to account for $20-87 \%$ of the total (soil + stem) $\mathrm{CH}_{4}$ efflux (Gauci et al., 2010; Pangala et al., 2013), but higher than the estimates from two upland forests where tree stem emissions equated to less than $1 \%$ of the soil sink (Machacova et al., 2016; Plain et al., 2019). The degree to which tree-mediated emissions may offset soil $\mathrm{CH}_{4}$ sinks, especially in well-drained tropical soils, remains highly uncertain, as evidenced by the wide range of stem emission estimates in the literature. Nevertheless, the consistent measurement of positive net stem $\mathrm{CH}_{4}$ emissions in our study sites suggests that stem $\mathrm{CH}_{4}$ emissions could be widespread in lowland tropical forests, and illustrates the need for further investigation. 
Our study provides evidence that tropical trees on well-drained soils can also emit $\mathrm{CH}_{4}$ (Fig. 3.2). However, the origin of stem emitted $\mathrm{CH}_{4}$ is a subject of ongoing debate, with studies suggesting microbial production of $\mathrm{CH}_{4}$ in the heartwood (Covey et al., 2012; Wang et al., 2016; Yip et al., 2019), soil-derived $\mathrm{CH}_{4}$ from low depths (Machacova et al., 2016; Pitz \& Megonigal, 2017; Barba et al., 2019b), and to a lesser extent from cryptogamic covers on stem bark (Lenhart et al., 2015). Nonetheless, our findings of decreasing stem $\mathrm{CH}_{4}$ emissions with height suggest a potential belowground (soil) origin, which concurs with the findings of other studies (Pangala et al., 2013; Pitz \& Megonigal, 2017; Barba et al., 2019b). Despite the soils acting as net $\mathrm{CH}_{4}$ sinks, it is possible that soil processes occurring in deeper soil depth could regulate the source of stem emitted $\mathrm{CH}_{4}$. Indeed, studies have found soils to produce $\mathrm{CH}_{4}$ at depth while acting as net sinks at the surface level (Maier et al., 2018). We found positive correlations of stem $\mathrm{CH}_{4}$ emissions with soil moisture, and with soil-air $\mathrm{CH}_{4}$ concentrations at $50 \mathrm{~cm}$ depth, which is consistent with root uptake of soil water containing dissolved $\mathrm{CH}_{4}$ produced in deep anoxic layers or methanogenic microsites (von Fischer \& Hedin, 2007; Brewer et al., 2018). This active transport of dissolved $\mathrm{CH}_{4}$ is likely driven by sap flow via transpiration streams of the trees, and then emitted to the atmosphere through the stem surfaces, bypassing the soil methanotrophic layers (Megonigal \& Guenther, 2008).

Our findings of decreasing stem emissions with height (Fig. 3.3) are consistent with previous results found in wetland and upland forests (Pangala et al., 2013, 2017; Wang et al., 2016; Pitz \& Megonigal, 2017; Barba et al., 2019b). As many of the studied trees had buttresses (e.g. Fig. 2.2), we measured stem emissions at trunk heights of $1.3 \mathrm{~m}$ above the ground, leaving an open question about lower stem $\mathrm{CH}_{4}$ emission rates. Mean $\mathrm{CH}_{4}$ emission of trees growing in a floodplain forest were found to decrease from 132 to $73 \mu \mathrm{g} \mathrm{C} \mathrm{m}^{-2} \mathrm{~h}^{-1}$ when measuring at trunk heights of 15 and $70 \mathrm{~cm}$, respectively (Terazawa et al., 2007). Similarly, $\mathrm{CH}_{4}$ emission of temperate upland trees were $19.9 \mu \mathrm{g} \mathrm{C} \mathrm{m}^{-2} \mathrm{~h}^{-1}$ at a trunk height of $75 \mathrm{~cm}$, reducing to 12.1 
$\mu \mathrm{g} \mathrm{C} \mathrm{m}^{-2} \mathrm{~h}^{-1}$ at an upper stem height of $150 \mathrm{~cm}$ (Barba et al., 2019b). The pattern is similar in tropical wetland forests, where stem emissions were found to range from 139 to $13 \mu \mathrm{g} \mathrm{C} \mathrm{m}{ }^{-2}$ $\mathrm{h}^{-1}$ at stem heights of 20-50, 60-90 and 100-130 cm (Pangala et al., 2013). These findings, coupled with our measurements of decreasing stem emissions with height suggest that there may be high emissions occurring at lower tree height, and possibly an underestimation of tree stem emissions from this important tropical region. Further research efforts are necessary to provide additional insights into mechanisms of stem $\mathrm{CH}_{4}$ production and magnitudes, in order to improve regional and global $\mathrm{CH}_{4}$ budget estimations.

\subsubsection{Factors controlling temporal and spatial variability of soil fluxes}

Studies have shown that soil moisture is the dominant factor controlling the seasonal variation in soil $\mathrm{CH}_{4}$ and $\mathrm{CO}_{2}$ fluxes in tropical systems (Verchot et al., 2000; Veldkamp et al., 2013; Matson et al., 2017; Wanyama et al., 2019). Indeed, we found a positive correlation between soil $\mathrm{CH}_{4}$ fluxes and WFPS in both land uses, which is consistent with diffusional limitation of atmospheric $\mathrm{CH}_{4}$ into the soil at high soil moisture conditions (Keller \& Reiners, 1994). Such inhibited diffusion of $\mathrm{CH}_{4}$ from the atmosphere into the soil affects methanotrophic $\mathrm{CH}_{4}$ oxidation, and/or creates conditions for anaerobic decomposition by methanogenic archaea, thereby producing $\mathrm{CH}_{4}$. However, the effect of soil moisture changes on soil $\mathrm{CH}_{4}$ uptake was less pronounced in our study, as indicated by the similar $\mathrm{CH}_{4}$ uptake rates between the wet and dry season in both land uses (Tables S3.1 and S3.2). We also found strong indications of potential $\mathrm{N}$ limitation on $\mathrm{CH}_{4}$ uptake in the cacao agroforestry, as shown by the negative correlation of soil $\mathrm{CH}_{4}$ fluxes with soil $\mathrm{NH}_{4}{ }^{+}$content, and the positive correlation of $\mathrm{CH}_{4}$ fluxes with aluminium saturation (see Sect. 3.4). $\mathrm{CH}_{4}$ and $\mathrm{NH}_{4}{ }^{+}$oxidizers compete for the methane monooxygenase enzyme responsible for both the oxidation of $\mathrm{CH}_{4}$ to $\mathrm{CO}_{2}$ and $\mathrm{NH}_{4}{ }^{+}$to $\mathrm{NO}_{2}{ }^{-}$ (Bedard \& Knowles, 1989). As such, the activities of methanotrophs can be inhibited by increasing $\mathrm{NH}_{4}{ }^{+}$availability in the soil. Additionally, the intermediate and end products of 
methanotrophic $\mathrm{NH}_{4}^{+}$oxidation have been found to be toxic to soil methanotrophic bacteria (Schnell \& King, 1994), which may also inhibit $\mathrm{CH}_{4}$ consumption. Indications of the inhibitory effect of soil $\mathrm{NH}_{4}{ }^{+}$content on methanotrophic activity have been reported for tropical forests in Ecuador (Wolf et al., 2012), Panama (Veldkamp et al., 2013; Matson et al., 2017), Australia (Kiese et al., 2003) and Kenya (Wanyama et al., 2019), while both increasing $\mathrm{NH}^{+}$availability and exchangeable $\mathrm{Al}$ in the soil have been shown to be toxic for both plants and methanotrophs in a tropical forest in Indonesia (Hassler et al., 2015).

Soil texture has been shown to largely control atmospheric $\mathrm{CH}_{4}$ uptake by soils, due to its direct effect on gas diffusivity into the soil (Veldkamp et al., 2013). In their review of studies conducted in (sub)tropical forests, Veldkamp et al. (2013) found annual soil $\mathrm{CH}_{4}$ fluxes to positively correlate with clay contents, which is consistent with the findings of this study. A high clay content reduces the diffusivity of atmospheric $\mathrm{CH}_{4}$ into the soil, thereby limiting aerobic $\mathrm{CH}_{4}$ oxidation and consumption, while increasing anaerobic $\mathrm{CH}_{4}$ production (Keller et al., 1993; Veldkamp et al., 2008). For such clayey soils such as in our sites, $\mathrm{CH}_{4}$ uptake also decreases at high WFPS due to inhibited diffusion of atmospheric $\mathrm{CH}_{4}$ into the soil because of the high soil water content. Indeed, for our cacao agroforestry sites, Biba Yezoum had a lower clay content (Table 2.1) and a lower WFPS (Table 2.4) compared to the Aloum, and hence had correspondingly higher soil $\mathrm{CH}_{4}$ uptake (Tables 3.1).

Soil $\mathrm{CO}_{2}$ fluxes at our sites showed clear seasonal variability (Tables S3.1 and S3.2), controlled by soil water content. We measured the highest soil $\mathrm{CO}_{2}$ fluxes at the beginning of our measurement period (Fig. 3.1), which coincided with the end of the rainy season when soil mineralization activity was still high. The lower soil $\mathrm{CO}_{2}$ fluxes in the dry season may reflect water limitation of plant root and soil microbial activity as well as limited litter decomposition due to low soil moisture content (Yavitt et al., 2004). The relationship between soil $\mathrm{CO}_{2}$ fluxes 
and WFPS reflected the parabolic relationship typically found in tropical forest studies, with the highest soil $\mathrm{CO}_{2}$ fluxes measured at field capacity (WFPS between 50 and 55\%), after which increasing soil moisture content inhibited soil $\mathrm{CO}_{2}$ production in the soil, and/or slowed the diffusion of soil $\mathrm{CO}_{2}$ from the soil (Schwendenmann et al., 2003; Sotta et al., 2006; Koehler et al., 2009a; van Straaten et al., 2011; Hassler et al., 2015). The positive correlation of soil $\mathrm{CO}_{2}$ emissions with sand content across our sites and land uses was similar to the findings of other studies conducted in tropical forests (Silver et al., 2000; Sotta et al., 2006). Sandy soils tend to have higher root biomass, and consequently, higher autotrophic root respiration, which has been shown to contribute up to 35\% of soil respiration (Silver et al., 2000; van Straaten et al., 2011).

\subsubsection{Effects of land-use change on soil $\mathrm{CO}_{2}$ and $\mathrm{CH}_{4}$ fluxes}

Our mean soil $\mathrm{CO}_{2}$ emissions from the forests (Table 3.1) were within the range of values (93$228 \mathrm{mg} \mathrm{C} \mathrm{m}^{-2} \mathrm{~h}^{-1}$ ) reported for tropical rainforests on Ferralsol soils in Central and South America (Davidson et al., 2000b, 2004; Schwendenmann et al., 2003; Chambers et al., 2004; Keller et al., 2005; Sotta et al., 2006; Matson et al., 2017). Compared to the few studies conducted in Africa, mean soil $\mathrm{CO}_{2}$ emissions from our forests were higher than those reported for tropical montane forests in Kenya (71.8-95.2 $\mathrm{mg} \mathrm{C} \mathrm{m}^{-2} \mathrm{~h}^{-1}$; Wanyama et al., 2019; Werner et al., 2007). For Werner et al. (2007), their short measuring campaign (3 months), which included two dry months, may have resulted in lower soil $\mathrm{CO}_{2}$ emissions compared to our study. The forest sites in Wanyama et al. (2019) study reportedly had low tree density, which could have affected autotrophic root respiration, leading to lower $\mathrm{CO}_{2}$ emissions.

Soil $\mathrm{CO}_{2}$ emissions did not differ between the forest and cacao agroforestry in this study (Table 3.1), in support of our first hypothesis. In tropical regions marked by periods of wet and dry conditions such as in our sites, soil $\mathrm{CO}_{2}$ fluxes are primarily controlled by soil moisture (Hassler et al., 2015; Matson et al., 2017; van Straaten et al., 2019), especially when there is 
little fluctuation in temperature (Schwendenmann et al., 2003). The lack of differences in soil water content between the two land uses (Table 2.4) may therefore have resulted in the similar soil $\mathrm{CO}_{2}$ fluxes. Moreover, forest conversion to cacao agroforestry in our study regions generally lacked heavy soil physical disturbance and preparation activities, which may have resulted in the similar soil texture and soil bulk density the two land uses (Table 2.1), and consequently, comparable $\mathrm{CO}_{2}$ emissions. Indeed, differences in soil characteristics such as soil texture (Sotta et al., 2006; da Costa et al., 2018), bulk density (Zhong et al., 2016), SOC and total N (Schwendenmann et al., 2003) have been shown to control spatial and temporal variation in soil $\mathrm{CO}_{2}$ fluxes. While we measured differences in SOC between the land uses in two of our sites (Table S1), it is possible that the microbial communities involved in heterotrophic respiration may have adapted to any differences in the quantity of substrate between the forest and cacao agroforest, resulting in their similar soil $\mathrm{CO}_{2}$ fluxes. Additionally, the high density of shade trees in the cacao agroforestry and their comparable basal area with the forests (Table S2.1) may have partly offset any differences in autotrophic root respiration between the two land uses. da Costa et al. (2018) also presented similar results where soil $\mathrm{CO}_{2}$ emissions did not differ between cacao agroforestry and a reference forest in Brazil. Similarly, Hassler et al. (2015) found no differences in soil $\mathrm{CO}_{2}$ emissions between jungle rubber agroforestry and forests in Indonesia. Our mean soil $\mathrm{CO}_{2}$ fluxes from the cacao agroforestry (Table 3.1) were comparable to those reported for cacao agroforestry systems in Brazil and Indonesia (125-137 mg C m${ }^{-2} \mathrm{~h}^{-1}$; da Costa et al., 2018; van Straaten et al., 2010).

Our forest sites acted as sinks of atmospheric $\mathrm{CH}_{4}$ (Fig. 3.1), similarly to what has been found in previous studies conducted on well-drained soils (e.g., Werner et al., 2007; Veldkamp et al., 2013; Wanyama et al., 2019). The mean soil $\mathrm{CH}_{4}$ uptake from our forest sites (Table 3.1) was within the range of other reported values for (sub)tropical lowland forests $(-6.28$ to -55.9 $\mu \mathrm{g} \mathrm{C} \mathrm{m}{ }^{-2} \mathrm{~h}^{-1}$; summarized by Veldkamp et al., 2013), but higher than those found for three 
lowland forests on Ferralsol soils in Panama (-10.7 to $-22.6 \mu \mathrm{g} \mathrm{C} \mathrm{m}^{-2} \mathrm{~h}^{-1}$; Matson et al., 2017). The latter study has higher clay contents compared to our study sites, which explains their correspondingly lower $\mathrm{CH}_{4}$ uptake rate. Compared to measurements conducted in sub-Saharan Africa, our lowland forests had comparable soil $\mathrm{CH}_{4}$ uptake rates as those reported for tropical montane forests in Kenya (-35.4 to $-66.2 \mu \mathrm{g} \mathrm{C} \mathrm{m}{ }^{-2} \mathrm{~h}^{-1}$; Wanyama et al., 2019) and in Tanzania (-31.0 to $-44.6 \mu \mathrm{g} \mathrm{C} \mathrm{m}^{-2} \mathrm{~h}^{-1}$; Gütlein et al., 2018). Conversely, our mean soil $\mathrm{CH}_{4}$ uptake was lower than reported for tropical montane forests in Kenya $\left(-56.4 \mu \mathrm{g} \mathrm{C} \mathrm{m} \mathrm{m}^{-2} \mathrm{~h}^{-1}\right.$; Werner et al., 2007), which had a comparably sandy texture compared to our sites.

In line with our first hypothesis, soil $\mathrm{CH}_{4}$ fluxes did not differ between the forest and cacao agroforestry at each site (Table 3.1). All our cacao sites were unfertilized and the soils were minimally disturbed, as reflected in the comparable soil texture (i.e. clay contents; Table 2.1) and soil moisture content (Table 2.4) between the two land uses. Since atmospheric $\mathrm{CH}_{4}$ diffusion into the soil has been suggested as the main limitation of soil $\mathrm{CH}_{4}$ oxidation by methanotrophic bacteria in the soil (Palm et al., 2002; Veldkamp et al., 2013), the comparable soil texture and soil moisture content between the forest and cacao agroforestry may be the primary reason for the similar $\mathrm{CH}_{4}$ rates.

Cacao agroforestry in our study (Table 3.1) had slightly higher soil $\mathrm{CH}_{4}$ uptake than a managed homegarden in Tanzania $\left(-32.6 \mu \mathrm{g} \mathrm{C} \mathrm{m}^{-2} \mathrm{~h}^{-1}\right.$; Gütlein et al., 2018) and an agroforestry system in Peru (-24.2 $\mu \mathrm{g} \mathrm{C} \mathrm{m}^{-2} \mathrm{~h}^{-1}$; (Palm et al., 2002), and was also higher than a jungle rubber agroforestry in Indonesia (-20.8 to $-26.9 \mu \mathrm{g} \mathrm{C} \mathrm{m}^{-2} \mathrm{~h}^{-1}$; Hassler et al., 2015). Our mean soil $\mathrm{CH}_{4}$ uptake in the cacao agroforestry were also higher than the reported average for agroforestry systems worldwide $\left(-18.3 \mu \mathrm{g} \mathrm{C} \mathrm{m}^{-2} \mathrm{~h}^{-1}\right.$; Kim et al., 2016a). These trends in soil $\mathrm{CH}_{4}$ fluxes may be explained by differences in gas diffusivity resulting from compaction and soil fertility; the agroforestry systems in Gütlein et al. (2018) study sites had comparably higher 
soil bulk densities than our cacao sites. Moreover, the higher soil $\mathrm{CH}_{4}$ uptake in our cacao agroforestry compared to the jungle rubber agroforestry (Hassler et al., 2015) may be the result of our comparably higher soil $\mathrm{NO}_{3}{ }^{-}$content, which have been found to simulate $\mathrm{CH}_{4}$ consumption and/or reduce its production in the soil (Veldkamp et al., 2013; Matson et al., 2017). This could also explain the lower $\mathrm{CH}_{4}$ uptake rate reported by Kim et al. (2016a) for the reviewed cacao agroforestry sites, in which ammonium- $\mathrm{N}$ fertilizers have been applied. As discussed above, increasing $\mathrm{NH}_{4}{ }^{+}$concentrations in the soil owing to nitrogenous fertilizer applications can inhibit $\mathrm{CH}_{4}$ oxidation rates (Veldkamp et al., 2001; Bodelier \& Laanbroek, 2004).

\subsection{Conclusions}

Our study provides evidence that tropical trees on well-drained, highly weathered soils represent potential $\mathrm{CH}_{4}$ emission pathways. Stem contribution to total $\mathrm{CH}_{4}$ fluxes suggests that tropical soils may be a weaker sink of atmospheric $\mathrm{CH}_{4}$ than previously estimated. Positive correlations of stem $\mathrm{CH}_{4}$ emissions with WFPS and soil-air $\mathrm{CH}_{4}$ concentrations points to a belowground origin of stem $\mathrm{CH}_{4}$ emissions. However, the consistently high $\mathrm{CH}_{4}$ emissions from a few of our sampled trees suggests there may be other contributing mechanisms. These findings highlight the need for additional studies to constrain the magnitude and mechanisms of stem $\mathrm{CH}_{4}$ fluxes in tropical well-drained forests, so that this important $\mathrm{CH}_{4}$ source can be accounted for in GHG budget estimations. In contrast to other studies, stem $\mathrm{CH}_{4}$ emissions did not differ among tree species in our study. Overall, we did not observe any effects of land-use change on stem and soil $\mathrm{CH}_{4}$ and $\mathrm{CO}_{2}$ fluxes, due to similarities in soil texture and soil moisture content between the forest and cacao agroforestry. 


\subsection{Acknowledgement}

This study was funded by the German Research Foundation (DFG, VE 219/14-1, STR 1375/1-

1). We gratefully acknowledge our counterparts in Cameroon, the International Institute for Tropical Agriculture (IITA) or granting us access and use of their storage facilities. We are grateful to our Cameroonian field assistants: Leonel Boris Gadjui Youatou, Yannick Eyenga Alfred, Denis Djiyo, and all the field workers for their great support with field measurements. We also thank the village leaders and local plot owners for granting us access to their forest and cacao farms. We thank Andrea Bauer, Kerstin Langs and Martina Knaust for their assistance with laboratory analyses.

\subsection{References}

Allen, R. G., Pereira, L. S., Raes, D., \& Smith, M. (1998). Determination of ET 0 , crop evapotranspiration. Guidelines for Computing Crop Water Requirements-FAO Irrigation and Drainage Paper 56, 309. Retrieved from http://www.hidmet.gov.rs/podaci/agro/table of contens_files.pdf

Barba, J., Bradford, M. A., Brewer, P. E., Bruhn, D., Covey, K. R., van Haren, J., et al. (2019a). Methane emissions from tree stems: a new frontier in the global carbon cycle. New Phytologist (Vol. 222). https://doi.org/10.1111/nph.15582

Barba, J., Poyatos, R., \& Vargas, R. (2019b). Automated measurements of greenhouse gases fluxes from tree stems and soils: magnitudes, patterns and drivers. Scientific Reports, 9(1), 1-13. https://doi.org/10.1038/s41598-019-39663-8

Bedard, C., \& Knowles, R. (1989). CO Oxidation by Methanotrophs and Nitrifiers. Microbiology, 53(1), 68-84. Retrieved from http://apps.isiknowledge.com/full_record.do?product=UA\&search_mode=GeneralSearch \&qid=11\&SID=X16536DGgEAkOn8a882\&page $=1 \&$ doc $=1 \&$ colname $=$ WOS

Bodelier, P. L. E., \& Laanbroek, H. J. (2004). Nitrogen as a regulatory factor of methane oxidation in soils and sediments. FEMS Microbiology Ecology, 47(3), 265-277. https://doi.org/10.1016/S0168-6496(03)00304-0

Brewer, P. E., Calderón, F., Vigil, M., \& von Fischer, J. C. (2018). Impacts of moisture, soil respiration, and agricultural practices on methanogenesis in upland soils as measured with stable isotope pool dilution. Soil Biology and Biochemistry, 127, 239-251. https://doi.org/10.1016/j.soilbio.2018.09.014

Chambers, J. Q., Tribuzy, E. S., Toledo, L. C., Crispim, B. F., Higuchi, N., Dos Santos, J., et al. (2004). Respiration from a tropical forest ecosystem: Partitioning of sources and low carbon use efficiency. Ecological Applications, 14(4 SUPPL.), 72-88.

https://doi.org/10.1890/01-6012 
da Costa, E. N. D., de Souza, M. F. L., Lima Marrocos, P. C., Lobão, D., \& da Silva, D. M. L. (2018). Soil organic matter and CO2 fluxes in small tropical watersheds under forest and cacao agroforestry. PLoS ONE, 13(7), 1-22. https://doi.org/10.1371/journal.pone.0200550

Covey, K. R., \& Megonigal, J. P. (2019). Methane production and emissions in trees and forests. New Phytologist, 222(1), 35-51. https://doi.org/10.1111/nph.15624

Covey, K. R., Wood, S. A., Warren, R. J., Lee, X., \& Bradford, M. A. (2012). Elevated methane concentrations in trees of an upland forest. Geophysical Research Letters, 39(15), 1-6. https://doi.org/10.1029/2012GL052361

Davidson, E. A., Verchot, L. V., Henrique Cattânio, J., Ackerman, I. L., \& Carvalho, J. E. M. (2000). Effects of soil water content on soil respiration in forests and cattle pastures of eastern Amazonia. Biogeochemistry, 48(1), 53-69. https://doi.org/10.1023/A:1006204113917

Davidson, E. A., Ishida, F. Y., \& Nepstad, D. C. (2004). Agricultural \& Applied Economics Budgets. Global Change Biology, 10(5), 718-730. https://doi.org/10.1111/j.15298817.2003.00762.x

Dutaur, L., \& Verchot, L. V. (2007). A global inventory of the soil CH4 sink. Global Biogeochemical Cycles, 21(4), 1-9. https://doi.org/10.1029/2006GB002734

von Fischer, J. C., \& Hedin, L. O. (2007). Controls on soil methane fluxes: Tests of biophysical mechanisms using table isotope tracers. Global Biogeochemical Cycles, 21(2), 1-9. https://doi.org/10.1029/2006GB002687

Gauci, V., Gowing, D. J. G., Hornibrook, E. R. C., Davis, J. M., \& Dise, N. B. (2010). Woody stem methane emission in mature wetland alder trees. Atmospheric Environment. https://doi.org/10.1016/j.atmosenv.2010.02.034

Gütlein, A., Gerschlauer, F., Kikoti, I., \& Kiese, R. (2018). Impacts of climate and land use on $\mathrm{N} 2 \mathrm{O}$ and $\mathrm{CH} 4$ fluxes from tropical ecosystems in the Mt. Kilimanjaro region, Tanzania. Global Change Biology, 24, 1239-1255. https://doi.org/10.1111/gcb.13944

Gwanfogbe, M., Meligui, A., Moukam, J., \& Nguoghia, J. (1983). Geography of Cameroon. Macmillan Education Ltd, Hong Kong.

Hashimoto, S., Carvalhais, N., Ito, A., Migliavacca, M., Nishina, K., \& Reichstein, M. (2015). Global spatiotemporal distribution of soil respiration modeled using a global database. Biogeosciences, 12(13), 4121-4132. https://doi.org/10.5194/bg-12-4121-2015

Hassler, E., Corre, M. D., Tjoa, A., Damris, M., Utami, S. R., \& Veldkamp, E. (2015). Soil fertility controls soil-atmosphere carbon dioxide and methane fluxes in a tropical landscape converted from lowland forest to rubber and oil palm plantations.

Biogeosciences Discussions, 12(12), 9163-9207. https://doi.org/10.5194/bgd-12-91632015

IPCC. (2013). Climate Change 2013: The Physical Science Basis. Contribution of Working Group I to the Fifth Assessment Report of the Intergovernmental Panel on Climate Change [Stocker, T.F., D. Qin, G.-K. Plattner, M. Tignor, S.K. Allen, J. Boschung, A. Nauels, Y. Xia,. Cambridge University Press, Cambridge, United Kingdom and New York, NY, USA. 
IUSS Working Group WRB. (2015). World Reference Base for Soil Resources 2014, update 2015 International soil classification system for naming soils and creating legends for soil maps. World Soil Resources Reports No. 106. FAO, Rome.

Keller, M., \& Matson, P. A. (1994). Biosphere-Atmosphere Exchange of Trace Gases in the Tropics: Evaluating the Effects of Land Use Changes BT - Global AtmosphericBiospheric Chemistry. In R. G. Prinn (Ed.) (pp. 103-117). Boston, MA: Springer US. https://doi.org/10.1007/978-1-4615-2524-0_7

Keller, M., \& Reiners, W. A. (1994). Soil-atmosphere exchange of nitrous oxide, nitric oxide, and methane under secondary succession of pasture to forest in the Atlantic lowlands of Costa Rica. Global Biogeochemical Cycles, 8(4), 399-409. https://doi.org/10.1029/94GB01660

Keller, M., Veldkamp, E., Weitz, A. M., \& Reiners, W. A. (1993). Effect of pasture age on soil trace-gas emissions from a deforested area of Costa Rica. Nature, 365(6443), 244 246. https://doi.org/10.1038/365244a0

Keller, M., Varner, R., Dias, J. D., Silva, H., Crill, P., De Oliveira, R. C., \& Asner, G. P. (2005). Soil-atmosphere exchange of nitrous oxide, nitric oxide, methane, and carbon dioxide in logged and undisturbed forest in the Tapajos National Forest, Brazil. Earth Interactions, 9(23), 1-28. https://doi.org/10.1175/EI125.1

Kiese, R., Hewett, B., Graham, A., \& Butterbach-Bahl, K. (2003). Seasonal variability of $\mathrm{N} 2 \mathrm{O}$ emissions and $\mathrm{CH} 4$ uptake by tropical rainforest soils of Queensland, Australia. Global Biogeochemical Cycles, 17(2), 1043. https://doi.org/10.1029/2002gb002014

Kim, D. G., Kirschbaum, M. U. F., \& Beedy, T. L. (2016a). Carbon sequestration and net emissions of $\mathrm{CH} 4$ and $\mathrm{N} 2 \mathrm{O}$ under agroforestry: Synthesizing available data and suggestions for future studies. Agriculture, Ecosystems and Environment, 226, 65-78. https://doi.org/10.1016/j.agee.2016.04.011

Kim, D. G., Thomas, A. D., Pelster, D. E., Rosenstock, T. S., \& Sanz-Cobena, A. (2016b). Greenhouse gas emissions from natural ecosystems and agricultural lands in sub-Saharan Africa: Synthesis of available data and suggestions for further research. Biogeosciences, 13(16), 4789-4809. https://doi.org/10.5194/bg-13-4789-2016

Kirschke, S., Bousquet, P., Ciais, P., Saunois, M., Canadell, J. G., Dlugokencky, E. J., et al. (2013). Three decades of global methane sources and sinks. Nature Geoscience, 6(10), 813-823. https://doi.org/10.1038/ngeo1955

Koehler, B., Corre, M. D., Veldkamp, E., \& Sueta, J. P. (2009). Chronic nitrogen addition causes a reduction in soil carbon dioxide efflux during the high stem-growth period in a tropical montane forest but no response from a tropical lowland forest in decadal scale. Biogeosciences Discussions, 6(5), 8633-8660. https://doi.org/10.5194/bgd-6-8633-2009

Kroetsch, D., \& Wang, C. (2008). Particle size distribution. In Soil Sampling and Methods of Analysis, Second Edition (pp. 713-725).

Lenhart, K., Weber, B., Elbert, W., Steinkamp, J., Clough, T., Crutzen, P., et al. (2015). Nitrous oxide and methane emissions from cryptogamic covers. Global Change Biology, 21(10), 3889-3900. https://doi.org/10.1111/gcb.12995

Luo, Y., \& Zhou, X. (2006). Soil Respiration and the Environment. Amsterdam, Netherlands, Netherlands: Academic Press. https://doi.org/https://doi.org/10.1016/B978-0-12-088782- 


\section{X5000-1}

Machacova, K., Bäck, J., Vanhatalo, A., Halmeenmäki, E., Kolari, P., Mammarella, I., et al. (2016). Pinus sylvestris as a missing source of nitrous oxide and methane in boreal forest. Scientific Reports, 6(March), 1-8. https://doi.org/10.1038/srep23410

Maier, M., Machacova, K., Lang, F., Svobodova, K., \& Urban, O. (2018). Combining soil and tree-stem flux measurements and soil gas profiles to understand $\mathrm{CH} 4$ pathways in Fagus sylvatica forests. Journal of Plant Nutrition and Soil Science, 181(1), 31-35. https://doi.org/10.1002/jpln.201600405

Matson, A. L., Corre, M. D., Langs, K., \& Veldkamp, E. (2017). Soil trace gas fluxes along orthogonal precipitation and soil fertility gradients in tropical lowland forests of Panama. Biogeosciences, 14(14), 3509-3524. https://doi.org/10.5194/bg-14-3509-2017

Megonigal, J. P., \& Guenther, A. B. (2008). Methane emissions from upland forest soils and vegetation. Tree Physiology, 28(4), 491-498. https://doi.org/10.1093/treephys/28.4.491

Neubauer, S. C., \& Megonigal, J. P. (2015). Moving Beyond Global Warming Potentials to Quantify the Climatic Role of Ecosystems. Ecosystems, 18(6), 1000-1013. https://doi.org/10.1007/s10021-015-9879-4

Palm, C. A., Alegre, J. C., Arevalo, L., Mutuo, P. K., Mosier, A. R., \& Coe, R. (2002). Nitrous oxide and methane fluxes in six different land use systems in the Peruvian Amazon. Global Biogeochemical Cycles, 16(4), 1073. https://doi.org/10.1029/2001gb001855

Pangala, S. R., Moore, S., Hornibrook, E. R. C., \& Gauci, V. (2013). Trees are major conduits for methane egress from tropical forested wetlands. New Phytologist, 197(2), 524-531. https://doi.org/10.1111/nph.12031

Pangala, S. R., Gowing, D. J. G., Hornibrook, E. R. C., \& Gauci, V. (2014). Controls on methane emissions from Alnus glutinosa saplings. New Phytologist, 201(3), 887-896. https://doi.org/10.1111/nph.12561

Pangala, S. R., Hornibrook, E. R. C., Gowing, D. J. G., \& Gauci, V. (2015). The contribution of trees to ecosystem methane emissions in a temperate forested wetland. Global Change Biology, 21(7), 2642-2654. https://doi.org/10.1111/gcb.12891

Pangala, S. R., Enrich-Prast, A., Basso, L. S., Peixoto, R. B., Bastviken, D., Hornibrook, E. R. C., et al. (2017). Large emissions from floodplain trees close the Amazon methane budget. Nature, 552(7684), 230-234. https://doi.org/10.1038/nature24639

Pierret, A., Maeght, J. L., Clément, C., Montoroi, J. P., Hartmann, C., \& Gonkhamdee, S. (2016). Understanding deep roots and their functions in ecosystems: An advocacy for more unconventional research. Annals of Botany, 118(4), 621-635. https://doi.org/10.1093/aob/mcw130

Pitz, S. L., \& Megonigal, J. P. (2017). Temperate forest methane sink diminished by tree emissions. New Phytologist, 214(4), 1432-1439. https://doi.org/10.1111/nph.14559

Pitz, S. L., Megonigal, J. P., Chang, C. H., \& Szlavecz, K. (2018). Methane fluxes from tree stems and soils along a habitat gradient. Biogeochemistry, 137(3), 307-320. https://doi.org/10.1007/s10533-017-0400-3

Plain, C., Ndiaye, F. K., Bonnaud, P., Ranger, J., \& Epron, D. (2019). Impact of vegetation on 
the methane budget of a temperate forest. New Phytologist, 221(3), 1447-1456. https://doi.org/10.1111/nph.15452

R Core Team (2018). R: A language and environment for statistical computing. R Foundation for Statistical Computing, Vienna, Austria. URL http://www.R-project.org/.

Raich, J. W., \& Schlesinger, W. H. (1998). The global carbon dioxide flux in soil respiration and its relationship to vegetation and climate. Tellus $B, 44 B, 81-99$.

Saunois, M., Bousquet, P., Poulter, B., Peregon, A., Ciais, P., Canadell, J. G., et al. (2016). The global methane budget 2000-2012. Earth System Science Data, 8(2), 697-751. https://doi.org/10.5194/essd-8-697-2016

Schnell, S., \& King, G. M. (1994). Mechanistic analysis of ammonium inhibition of atmospheric methane consumption in forest soils. Applied and Environmental Microbiology, 60(10), 3514-3521. https://doi.org/10.1128/aem.60.10.3514-3521.1994

Schwendenmann, L., Veldkamp, E., Brenes, T., O’Brien, J. J., \& Mackensen, J. (2003). Spatial and temporal variation in soil $\mathrm{CO} 2$ efflux in an old-growth neotropical rain forest, La Selva, Costa Rica. Biogeochemistry, 64(1), 111-128. https://doi.org/10.1023/A:1024941614919

Silver, W. L., Neff, J., McGroddy, M., Veldkamp, E., Keller, M., \& Cosme, R. (2000). Effects of Soil Texture on Belowground Carbon and Nutrient Storage in a Lowland Amazonian Forest Ecosystem. Ecosystems, 3(2), 193-209. https://doi.org/10.1007/s100210000019

Sonwa, D. J., Nkongmeneck, B. A., Weise, S. F., Tchatat, M., Adesina, A. A., \& Janssens, M. J. J. (2007). Diversity of plants in cocoa agroforests in the humid forest zone of Southern Cameroon. Biodiversity and Conservation, 16(8), 2385-2400. https://doi.org/10.1007/s10531-007-9187-1

Sotta, E. D., Veldkamp, E., Guimarães, B. R., Paixão, R. K., Ruivo, M. L. P., \& Almeida, S. S. (2006). Landscape and climatic controls on spatial and temporal variation in soil CO2 efflux in an Eastern Amazonian Rainforest, Caxiuanã, Brazil. Forest Ecology and Management, 237(1-3), 57-64. https://doi.org/10.1016/j.foreco.2006.09.027

van Straaten, O., Veldkamp, E., Köhler, M., \& Anas, I. (2010). Spatial and temporal effects of drought on soil CO2 efflux in a cacao agroforestry system in Sulawesi, Indonesia. Biogeosciences, 7(4), 1223-1235. https://doi.org/10.5194/bg-7-1223-2010

van Straaten, O., Veldkamp, E., \& Corre, M. D. (2011). Simulated drought reduces soil CO 2 efflux and production in a tropical forest in Sulawesi, Indonesia . Ecosphere, 2(10), art119. https://doi.org/10.1890/es11-00079.1

van Straaten, O., Doamba, S. W. M. F., Corre, M. D., \& Veldkamp, E. (2019). Impacts of burning on soil trace gas fluxes in two wooded savanna sites in Burkina Faso. Journal of Arid Environments, 165(February), 132-140. https://doi.org/10.1016/j.jaridenv.2019.02.013

Terazawa, K., Ishizuka, S., Sakata, T., Yamada, K., \& Takahashi, M. (2007). Methane emissions from stems of Fraxinus mandshurica var. japonica trees in a floodplain forest. Soil Biology and Biochemistry, 39(10), 2689-2692.

Terazawa, K., Yamada, K., Ohno, Y., Sakata, T., \& Ishizuka, S. (2015). Spatial and temporal 
variability in methane emissions from tree stems of Fraxinus mandshurica in a cooltemperate floodplain forest. Biogeochemistry, 123(3), 349-362.

https://doi.org/10.1007/s10533-015-0070-y

Valentini, R., Arneth, A., Bombelli, A., Castaldi, S., Cazzolla Gatti, R., Chevallier, F., et al. (2014). A full greenhouse gases budget of africa: Synthesis, uncertainties, and vulnerabilities. Biogeosciences, 11(2), 381-407. https://doi.org/10.5194/bg-11-381-2014

Veldkamp, E., Weitz, A. M., \& Keller, M. (2001). Management effects on methane fluxes in humid tropical pasture soils. Soil Biology and Biochemistry, 33(11), 1493-1499. https://doi.org/10.1016/S0038-0717(01)00060-8

Veldkamp, E., Purbopuspito, J., Corre, M. D., Brumme, R., \& Murdiyarso, D. (2008). Land use change effects on trace gas fluxes in the forest margins of Central Sulawesi, Indonesia. Journal of Geophysical Research: Biogeosciences, 113(2), 1-11. https://doi.org/10.1029/2007JG000522

Veldkamp, E., Koehler, B., \& Corre, M. D. (2013). Indications of nitrogen-limited methane uptake in tropical forest soils. Biogeosciences, 10(8), 5367-5379. https://doi.org/10.5194/bg-10-5367-2013

Verchot, L. V., Davidson, E. A., Cattânio, J. H., \& Ackerman, I. L. (2000). Land-use change and biogeochemical controls of methane fluxes in soils of eastern Amazonia. Ecosystems, 3(1), 41-56. https://doi.org/10.1007/s100210000009

Wang, Z. P., Gu, Q., Deng, F. D., Huang, J. H., Megonigal, J. P., Yu, Q., et al. (2016). Methane emissions from the trunks of living trees on upland soils. The New Phytologist, 211(2), 429-439. https://doi.org/10.1111/nph.13909

Wang, Z. P., Han, S. J., Li, H. L., Deng, F. D., Zheng, Y. H., Liu, H. F., \& Han, X. G. (2017). Methane Production Explained Largely by Water Content in the Heartwood of Living Trees in Upland Forests. Journal of Geophysical Research: Biogeosciences, 122(10), 2479-2489. https://doi.org/10.1002/2017JG003991

Wanyama, I., Pelster, D. E., Butterbach-Bahl, K., Verchot, L. V., Martius, C., \& Rufino, M. C. (2019). Soil carbon dioxide and methane fluxes from forests and other land use types in an African tropical montane region. Biogeochemistry, 143(2), 171-190. https://doi.org/10.1007/s10533-019-00555-8

Warner, D. L., Villarreal, S., McWilliams, K., Inamdar, S., \& Vargas, R. (2017). Carbon Dioxide and Methane Fluxes From Tree Stems, Coarse Woody Debris, and Soils in an Upland Temperate Forest. Ecosystems, 20(6), 1205-1216. https://doi.org/10.1007/s10021-016-0106-8

Welch, B., Gauci, V., \& Sayer, E. J. (2019). Tree stem bases are sources of CH4 and N2O in a tropical forest on upland soil during the dry to wet season transition. Global Change Biology, 25(1), 361-372. https://doi.org/10.1111/gcb.14498

Werner, C., Kiese, R., \& Butterbach-Bahl, K. (2007). Soil-atmosphere exchange of N2O, $\mathrm{CH} 4$, and $\mathrm{CO} 2$ and controlling environmental factors for tropical rain forest sites in western Kenya. Journal of Geophysical Research, 112(3), D03308. https://doi.org/10.1029/2006JD007388

Wolf, K., Flessa, H., \& Veldkamp, E. (2012). Atmospheric methane uptake by tropical montane forest soils and the contribution of organic layers. Biogeochemistry, 111(1-3), 
469-483. https://doi.org/10.1007/s10533-011-9681-0

Yavitt, J. B., Wright, S. J., \& Wieder, R. K. (2004). Seasonal drought and dry-season irrigation influence leaf-litter nutrients and soil enzymes in a moist, lowland forest in Panama. Austral Ecology, 29(2), 177-188. https://doi.org/10.1111/j.14429993.2004.01334.x

Yip, D. Z., Veach, A. M., Yang, Z. K., Cregger, M. A., \& Schadt, C. W. (2019). Methanogenic Archaea dominate mature heartwood habitats of Eastern Cottonwood (Populus deltoides). New Phytologist, 222(1), 115-121. https://doi.org/10.1111/nph.15346

Zhong, Y., Yan, W., \& Shangguan, Z. (2016). The effects of nitrogen enrichment on soil CO2 fluxes depending on temperature and soil properties. Global Ecology and Biogeography, 25(4), 475-488. https://doi.org/10.1111/geb.12430

\subsection{Appendix}

Table S3.1. Seasonal mean $( \pm \mathrm{SE}, n=4)$ stem $\mathrm{CH}_{4}$ flux, soil $\mathrm{CH}_{4}$ flux and soil $\mathrm{CO}_{2}$ flux in forests on highly weathered soils in the Congo Basin, Cameroon. Means followed by different lowercase letters indicate significant differences between seasons for each site (linear mixedeffect models with Tukey's HSD at $P \leq 0.05)$.

\begin{tabular}{llll}
\hline Site/season & $\begin{array}{l}\text { Stem } \mathrm{CH}_{4} \text { flux } \\
\left(\mu \mathrm{g} \mathrm{N} \mathrm{m}^{-2} \mathrm{stem} \mathrm{h}^{-1}\right)\end{array}$ & $\begin{array}{l}\text { Soil } \mathrm{CH}_{4} \text { flux } \\
\left(\mu \mathrm{g} \mathrm{N} \mathrm{m}^{-2} \mathrm{soil} \mathrm{h}^{-1}\right)\end{array}$ & $\begin{array}{l}\text { Soil CO } \mathrm{flux} \\
\left(\mathrm{mg} \mathrm{C} \mathrm{m}^{-2} \mathrm{soil} \mathrm{h}^{-1}\right)\end{array}$ \\
\hline Wet seasson & & $-34.9 \pm 4.7^{\mathrm{a}}$ & $121.1 \pm 10.0^{\mathrm{a}}$ \\
\hline Aloum & $5.70 \pm 0.88^{\mathrm{a}}$ & $-25.4 \pm 12.8^{\mathrm{a}}$ & $141.2 \pm 13.2^{\mathrm{a}}$ \\
Biba Yezoum & $4.18 \pm 0.40^{\mathrm{a}}$ & $-26.2 \pm 7.9^{\mathrm{a}}$ & $137.2 \pm 14.2^{\mathrm{a}}$ \\
Tomba & $0.31 \pm 0.07^{\mathrm{a}}$ & & \\
\hline Dry season & & $-39.1 \pm 4.3^{\mathrm{a}}$ & $94.7 \pm 6.0^{\mathrm{b}}$ \\
\hline Aloum & $4.97 \pm 0.82^{\mathrm{a}}$ & $-44.1 \pm 11.1^{\mathrm{a}}$ & $111.1 \pm 8.4^{\mathrm{b}}$ \\
Biba Yezoum & $4.01 \pm 0.16^{\mathrm{a}}$ & $-19.7 \pm 9.2^{\mathrm{a}}$ & $108.2 \pm 12.6^{\mathrm{b}}$ \\
Tomba & $0.19 \pm 0.05^{\mathrm{a}}$ & & \\
\hline
\end{tabular}


Table S3.2. Seasonal mean $( \pm \mathrm{SE}, n=4)$ stem $\mathrm{CH}_{4}$ flux, soil $\mathrm{CH}_{4}$ flux and soil $\mathrm{CO}_{2}$ flux in cacao agroforestry sites located on highly weathered soils in the Congo Basin, Cameroon. Means followed by different lowercase letters indicate significant differences between seasons for each site (linear mixed-effect models with Tukey's HSD at $P \leq 0.05$ ).

\begin{tabular}{llll}
\hline Site/season & $\begin{array}{l}\text { Stem } \mathrm{CH}_{4} \text { flux } \\
\left(\mu \mathrm{g} \mathrm{N} \mathrm{m}^{-2} \mathrm{stem} \mathrm{h}^{-1}\right)\end{array}$ & $\begin{array}{l}\text { Soil CH} \text { flux } \\
\left(\mu \mathrm{g} \mathrm{N} \mathrm{m}^{-2} \mathrm{soil} \mathrm{h}^{-1}\right)\end{array}$ & $\begin{array}{l}\text { Soil CO } \mathrm{flux} \\
\left(\mathrm{mg} \mathrm{C} \mathrm{m}^{-2} \mathrm{soil} \mathrm{h}^{-1}\right)\end{array}$ \\
\hline Wet seasson & & & \\
\hline Aloum & $0.86 \pm 0.13^{\mathrm{a}}$ & $-12.3 \pm 3.8^{\mathrm{a}}$ & $122.7 \pm 11.8^{\mathrm{a}}$ \\
Biba Yezoum & $0.60 \pm 0.10^{\mathrm{a}}$ & $-49.5 \pm 2.3^{\mathrm{a}}$ & $150.6 \pm 11.4^{\mathrm{a}}$ \\
Tomba & $1.97 \pm 0.60^{\mathrm{a}}$ & $-36.8 \pm 6.5^{\mathrm{a}}$ & $143.3 \pm 15.0^{\mathrm{a}}$ \\
\hline Dry season & & & \\
\hline Aloum & $0.81 \pm 0.18^{\mathrm{a}}$ & $-34.1 \pm 7.8^{\mathrm{b}}$ & $91.1 \pm 7.01^{\mathrm{b}}$ \\
Biba Yezoum & $0.60 \pm 0.20^{\mathrm{a}}$ & $-59.5 \pm 4.4^{\mathrm{a}}$ & $104.4 \pm 10.3^{\mathrm{b}}$ \\
Tomba & $1.64 \pm 0.30^{\mathrm{a}}$ & $-39.9 \pm 8.1^{\mathrm{a}}$ & $114.3 \pm 12.4^{\mathrm{b}}$ \\
\hline
\end{tabular}




\section{Chapter 4}

SYNTHESIS 


\subsection{Key findings of this thesis}

\section{Chapter 2: Stem and soil nitrous oxide fluxes from rainforest and cacao agroforest}

The conversion of forests to extensively managed cacao agroforestry systems had no effect on stem and soil nitrous oxide $\left(\mathrm{N}_{2} \mathrm{O}\right)$ emissions, due to similarities in soil water content, soil texture and leguminous tree density in both land uses. All the studied trees emitted measureable $\mathrm{N}_{2} \mathrm{O}$ at some point during the measurement period. In contrast to findings from other studies (Wen et al., 2017; Welch et al., 2019), stem $\mathrm{N}_{2} \mathrm{O}$ emissions did not differ among the different tree species in our study, which supported our spatial extrapolation based on diameter at breast height $(\mathrm{DBH})$ of trees in our sites. The up-scaled $\mathrm{N}_{2} \mathrm{O}$ fluxes suggest that trees could be important to consider in $\mathrm{N}_{2} \mathrm{O}$ budgets, with the potential to overlook up to $38 \%$ of $\mathrm{N}_{2} \mathrm{O}$ emissions in the forests and $15 \%$ of $\mathrm{N}_{2} \mathrm{O}$ emissions in cacao agroforests if tree stems are not considered in the ecosystem $\mathrm{N}_{2} \mathrm{O}$ budget. These estimates of tree contributions to total stem+soil fluxes are the highest reported for any upland forests, and the first estimates for

tropical Africa. ${ }^{15} \mathrm{~N}$-isotope tracing from soil mineral nitrogen $(\mathrm{N})$ to stem-emitted ${ }^{15} \mathrm{~N}_{2} \mathrm{O}$ together with the relationships between stem and soil $\mathrm{N}_{2} \mathrm{O}$ emissions as well as their controlling factors suggest that tree stem $\mathrm{N}_{2} \mathrm{O}$ emissions originate mainly from produced $\mathrm{N}_{2} \mathrm{O}$ in the soil.

\section{Chapter 3: Stem and soil methane and soil carbon dioxide fluxes from rainforest and cacao agroforest}

Forest conversion to cacao agroforestry had no effect on stem and soil methane $\left(\mathrm{CH}_{4}\right)$ fluxes. Similarly, soil carbon dioxide $\left(\mathrm{CO}_{2}\right)$ fluxes did not differ between the two land uses. The lack of differences in soil $\mathrm{CH}_{4}$ and $\mathrm{CO}_{2}$ fluxes was due to the comparable soil texture and soil moisture content between the two land uses, which influences gas diffusivity into and out of the soil. Tree stems were a net source of $\mathrm{CH}_{4}$, and our results points to a possible soil origin driven by transpiration. Our upscaling suggests that tree stem emissions offset $3-18 \%$ of the annual soil $\mathrm{CH}_{4}$ sink in both land uses. Our results demonstrate that tropical trees on well- 
drained soils represent potential $\mathrm{CH}_{4}$ emission pathways that have largely been ignored, thus highlighting the urgent need for additional studies to further constrain regional and global $\mathrm{CH}_{4}$ budgets.

\subsection{Revising the African greenhouse gas budget}

As discussed in previous chapters, trace gas budgets for the African continent is difficult to constrain due to limited number of in situ flux measurements, leaving considerable uncertainties in recent estimates. The most current estimates of the magnitude of trace gas fluxes from the African continent are from Valentini et al. (2014), who estimated the mean annual $\mathrm{N}_{2} \mathrm{O}$ emissions of natural ecosystems to be $1.13 \mathrm{Tg} \mathrm{N}_{2} \mathrm{O} \mathrm{\textrm {yr } ^ { - 1 }}$, with a standard deviation of $0.9 \mathrm{Tg}$ $\mathrm{N}_{2} \mathrm{O} \mathrm{yr}^{-1}$, signifying the high variability of the limited dataset used in the estimation. The range of uncertainty is similar for soil $\mathrm{CH}_{4}$ fluxes, with tropical humid forests estimated to emit 0.27 $\pm 0.16 \mathrm{Tg} \mathrm{CH}_{4} \mathrm{yr}^{-1}$, which is almost balanced by the net sink of seasonally dry forests $(-0.21 \pm$ $0.42 \mathrm{Tg} \mathrm{CH}_{4} \mathrm{yr}^{-1}$; Valentini et al., 2014). Given that we did not find land-use change effects on trace gas fluxes in our study, this sub-chapter aims to recalculate the source strength and sink of tropical forests in Africa, taken into consideration emissions from tree stems, which was not included in previous estimates. We only provide estimates for $\mathrm{N}_{2} \mathrm{O}$ and $\mathrm{CH}_{4}$, and not for $\mathrm{CO}_{2}$ because what we measured from our sites is not the net ecosystem $\mathrm{CO}_{2}$ fluxes. Additionally, we do not provide an estimate for agroforestry systems due to lack of studies on trace gas fluxes from unfertilized agroforestry systems in Africa.

Using the "measure and multiply" method commonly employed in bottom-up approaches (Schimel \& Potter, 1995; Corre et al., 1999), we estimated the $\mathrm{N}_{2} \mathrm{O}$ and $\mathrm{CH}_{4}$ fluxes for tropical forests in African by synthesizing currently available data on trace gas fluxes from in situ field measurements (Table 4.1). The total flux was calculated by multiplying the annual trace gas flux with the areal coverage of the land use (in this case, the area of tropical forest in 
Africa) as estimated from land cover maps using geographic information system (GIS) technology (Table 4.1). Trace gas fluxes were converted to $\mathrm{CO}_{2}$ equivalent $\left(\mathrm{CO}_{2}\right.$ eq. $)$ assuming global warming potentials (GWP) of $263 \mathrm{~kg} \mathrm{CO}_{2}$ eq. for $\mathrm{N}_{2} \mathrm{O}$ and $32 \mathrm{~kg} \mathrm{CO}_{2}$ eq. for $\mathrm{CH}_{4}$, over a 100-year time scale (Neubauer \& Megonigal, 2015). Tree stem contribution to total trace gas fluxes were emphasized by categorising the estimates into fluxes from soils only, and from soils + stems (Table 4.1).

Table 4.1. Mean $( \pm \mathrm{SE}) \mathrm{N}_{2} \mathrm{O}(n=16)$ and $\mathrm{CH}_{4}(n=10)$ fluxes from tropical rainforest in Africa

\begin{tabular}{|c|c|c|c|c|}
\hline & $\begin{array}{l}\text { Area }^{1} \\
\text { (Mha) }\end{array}$ & $\begin{array}{l}\mathrm{N}_{2} \mathrm{O} \text { emission } \\
\left(\mathrm{kg} \mathrm{N} \mathrm{ha}^{-1} \mathrm{yr}^{-1}\right)\end{array}$ & $\begin{array}{l}\mathrm{N}_{2} \mathrm{O} \text { source } \\
\text { strength } \\
\left(\mathrm{Tg} \mathrm{N} \mathrm{yr}{ }^{-1}\right)\end{array}$ & $\begin{array}{l}\mathrm{GWP}^{2} \\
\left(\mathrm{Tg} \mathrm{CO} \mathrm{CO}_{2} \text { eq. } \mathrm{yr}^{-1}\right)\end{array}$ \\
\hline Soil fluxes & 305.5 & $1.6 \pm 0.2$ & $0.50 \pm 0.10$ & $132 \pm 26$ \\
\hline \multirow[t]{2}{*}{ Soil + stem fluxes } & 305.5 & $1.7 \pm 0.2$ & $0.52 \pm 0.11$ & $137 \pm 29$ \\
\hline & $\begin{array}{l}\text { Area } \\
\text { (Mha) }\end{array}$ & $\begin{array}{l}\mathrm{CH}_{4} \text { emission } \\
\left(\mathrm{kg} \mathrm{C} \mathrm{ha}^{-1} \mathrm{yr}^{-1}\right)\end{array}$ & $\begin{array}{l}\mathrm{CH}_{4} \text { source } \\
\text { strength } \\
\left(\mathrm{Tg} \mathrm{C} \mathrm{yr}{ }^{-1}\right)\end{array}$ & $\begin{array}{l}\text { GWP } \\
\left(\mathrm{Tg} \mathrm{CO}_{2} \text { eq. } \mathrm{yr}^{-1}\right)\end{array}$ \\
\hline Soil fluxes & 305.5 & $-3.4 \pm 0.4$ & $-1.04 \pm 0.11$ & $-33 \pm 3$ \\
\hline Soil + stem fluxes & 305.5 & $-2.9 \pm 0.5$ & $-0.89 \pm 0.14$ & $-29 \pm 5$ \\
\hline
\end{tabular}

${ }^{1}$ Estimate from GlobCover 2009 (http://due.esrin.esa.int/page_globcover.php)

${ }^{2}$ GWP, global warming potential

Our estimated total $\mathrm{N}_{2} \mathrm{O}$ source strength for the African tropical forests (Table 4.1) were higher than the $0.34 \pm 0.08 \mathrm{Tg} \mathrm{N}_{2} \mathrm{O}-\mathrm{N} \mathrm{yr}^{-1}$ estimated by (Werner et al., 2007). Their estimate was based on $\mathrm{N}_{2} \mathrm{O}$ simulations from a data-calibrated mechanistic model (ForestDNDCtropica) coupled with a global GIS. As pointed out by the authors, site measured $\mathrm{N}_{2} \mathrm{O}$ fluxes do not always match with simulated $\mathrm{N}_{2} \mathrm{O}$ fluxes due to differences in soil properties and vegetation. Valentini et al. (2014) modelled the relationship between field-measured $\mathrm{N}_{2} \mathrm{O}$ emissions and annual precipitation, and estimated the $\mathrm{N}_{2} \mathrm{O}$ source strength of tropical forests in Africa to be 
$0.65 \mathrm{Tg} \mathrm{N}_{2} \mathrm{O}-\mathrm{N} \mathrm{yr}^{-1}$. Similarly, the estimated net $\mathrm{CH}_{4}$ sink strength of tropical forest $(-0.21 \mathrm{Tg}$ $\mathrm{N}_{2} \mathrm{O}-\mathrm{N} \mathrm{yr}^{-1}$ ) in Valentini et al. (2014) study was significantly lower than estimated in our study (Table 4.1). It is difficult to relate their estimated $\mathrm{CH}_{4}$ flux to our value, since they do not provide details on their upscaling method. Nevertheless, it is noteworthy that our estimated $\mathrm{N}_{2} \mathrm{O}$ source strength of $0.52 \mathrm{Tg} \mathrm{N}_{2} \mathrm{O}-\mathrm{N} \mathrm{yr}^{-1}$, together with the uncertainty $\left(0.11 \mathrm{Tg} \mathrm{N}_{2} \mathrm{O}-\mathrm{N} \mathrm{yr}{ }^{-1}\right)$, is within the range of previously reported values from bottom-up approaches, and shows that tropical forests in Africa are indeed important sources of global $\mathrm{N}_{2} \mathrm{O}$.

We also estimated the $\mathrm{N}_{2} \mathrm{O}$ source strength for the entire African continent using our measured fluxes and synthesized data from the literature (Table 4.2). When including emissions from tree stems, our estimated $\mathrm{N}_{2} \mathrm{O}$ source strength was higher than the other estimates, and is equivalent to $23 \%$ of global $\mathrm{N}_{2} \mathrm{O}$ emissions (Thompson et al., 2014). For all the estimation approaches considered, our estimated total $\mathrm{N}_{2} \mathrm{O}$ emission in Africa was in agreement with the previous estimates from Valentini et al. (2014) when excluding tree stem emissions (Table 4.2). The estimate from Thompson et al. (2014) were based on modelling of atmospheric observations and an inversion method, and included fluxes from coastal and ocean surfaces. It is therefore likely that their estimated $\mathrm{N}_{2} \mathrm{O}$ source strength for Africa will be smaller than our estimate when excluding oceanic fluxes. Similarly, our estimate was higher than the value reported by Huang et al. (2008) from atmospheric measurements and inversion models. The limited data from atmospheric inversions for the African continent makes it difficult to constrain trace gas emissions using top-down approaches (Tian et al., 2016), which may explain their comparably lower estimate. Our estimated $\mathrm{N}_{2} \mathrm{O}$ source strength was also higher than estimated by Tian et al. (2016) using a bottom-up approach; however, their estimate did not include emissions from $\mathrm{N}$ deposition and leaching, which is large enough to explain the discrepancy between the two estimates (Table 4.2). 
Table 4.2. Estimated annual $\mathrm{N}_{2} \mathrm{O}( \pm \mathrm{SE})$ emissions from the African continent

\begin{tabular}{|c|c|c|c|}
\hline Approach & $\mathrm{N}_{2} \mathrm{O}$-emitting pathways & $\begin{array}{l}\mathrm{N}_{2} \mathrm{O} \text { fluxes } \\
\left(\mathrm{Tg} \mathrm{N}_{2} \mathrm{O}-\mathrm{N} \mathrm{yr}{ }^{-1}\right)\end{array}$ & Study \\
\hline \multirow[t]{6}{*}{ Bottom-up } & Trees & $0.3 \pm 0.1$ & This study \\
\hline & Natural soils & $1.1 \pm 0.2$ & This study \\
\hline & Agriculture & $1.4 \pm 0.7$ & Kim et al. 2016 \\
\hline & Biomass burning & $0.3 \pm 0.0$ & Tian et al. 2016 \\
\hline & $\begin{array}{l}\text { Nitrogen depositions \& } \\
\text { nitrogen leaching }\end{array}$ & 0.68 & Valentini et al. 2014 \\
\hline & $\begin{array}{l}\text { Other natural sources } \\
\text { (wetlands, termite mounds, } \\
\text { savannah \& grasslands) }\end{array}$ & $0.2 \pm 0.0$ & Kim et al. 2016 \\
\hline \multicolumn{4}{|l|}{ Total emissions } \\
\hline (including trees) & & $3.9 \pm 0.7$ & This study \\
\hline Total emissions (no trees) & & $3.6 \pm 0.9$ & This study \\
\hline Bottom-up (no trees) & & $3.3 \pm 1.3$ & Valentini et al. 2014 \\
\hline Bottom-up (no trees) & & $2.9 \pm 0.3$ & Tian et al. 2016 \\
\hline Top-down & & 3.5 & Thompson et al. 2014 \\
\hline Top-down & & 2.9 & Huang et al. 2008 \\
\hline
\end{tabular}

We acknowledge, however, that our simple upscaling of trace gas fluxes from small scales to regional scales based on a few studies have a high degree of uncertainty, especially because we did not account for spatial and temporal differences in soil properties, vegetation and climate. Moreover, a central assumption of the "measure and multiply" approach is that the trace gas flux data used in the upscaling are representative for the investigated land use throughout the study region. Given the relatively few number of studies and the lack of data for some countries (Fig. 4.1), it is likely that the degree of uncertainty for the upscaled fluxes is higher than indicated in Tables 4.1 and 4.2. These limitations of our estimates for $\mathrm{N}_{2} \mathrm{O}$ and $\mathrm{CH}_{4}$ 
fluxes highlights the need for further investigations in Africa to provide additional insights on the natural sources and sinks of these important trace gases, and to improve estimations from this important region.

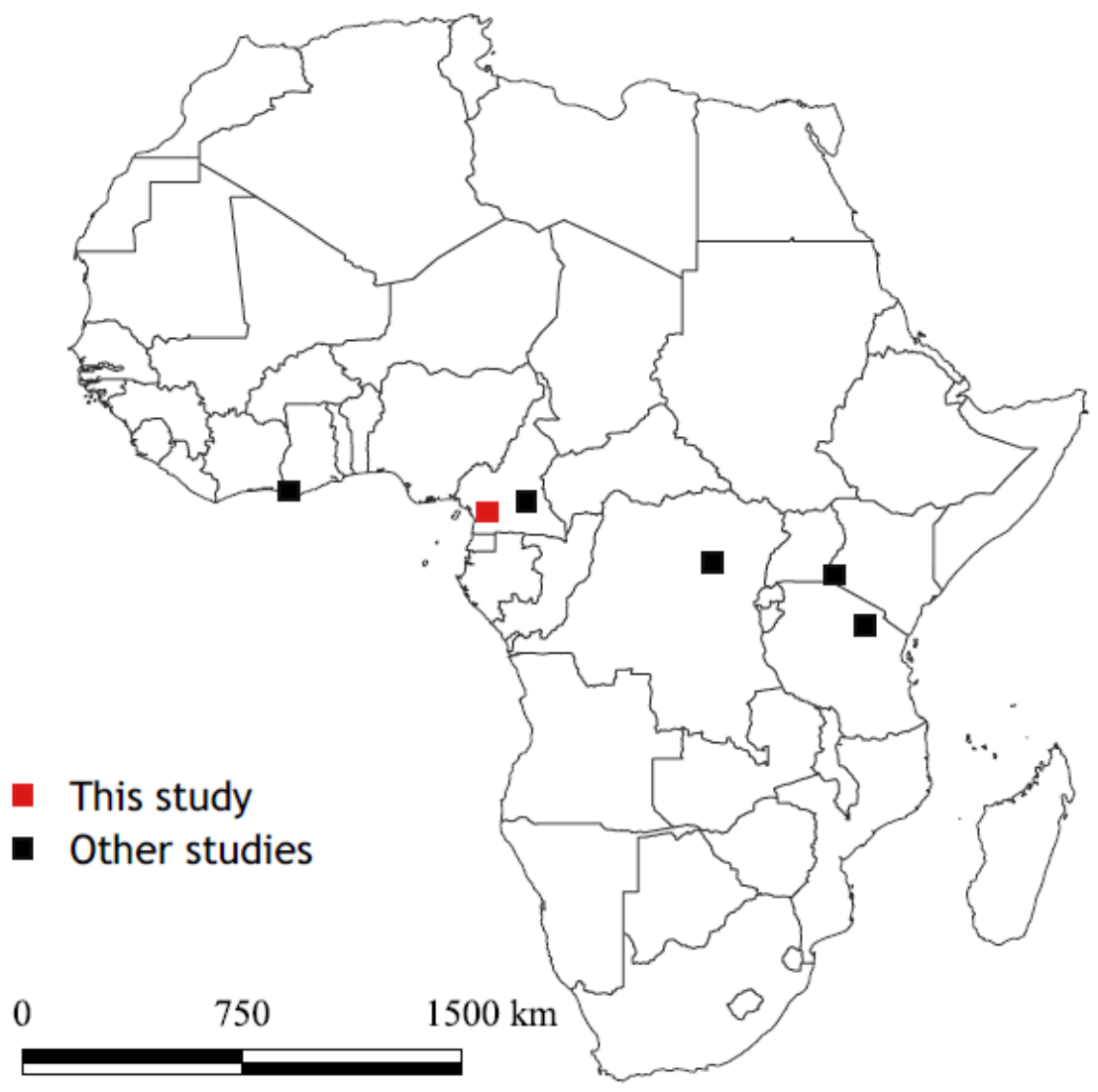

Figure 4.1. Map showing study sites of soil trace gas studies from moist natural forests in Africa.

\subsection{Tree stem emissions and implications for global greenhouse gas budgets}

This study provide the first attempt, albeit uncertain, to estimate the role of tree stem emissions in $\mathrm{N}_{2} \mathrm{O}$ and $\mathrm{CH}_{4}$ budgets in Africa. Tree stems accounted for $8 \%$ of the total $\mathrm{N}_{2} \mathrm{O}$ emissions in Africa (Table 4.2), and reduced the net $\mathrm{CH}_{4}$ sink of African rainforests by $15 \%$ (Table 4.1). The GWP of the forests was also higher when including tree stem emissions (Table 4.1). These findings have important implications for global greenhouse gas budgets, considering that welldrained soils such as found in our study sites constitute the largest terrestrial $\mathrm{CH}_{4}$ sink (Saunois 
et al., 2016). It is possible that even small stem $\mathrm{CH}_{4}$ emissions might change a forest from a net sink to a net source (Shoemaker et al., 2014; Pitz \& Megonigal, 2017). This was partly the case in our study; when including the consistently high emitting trees (Fig. 3.4) in our upscaling method, the balance between soil and stem $\mathrm{CH}_{4}$ fluxes indicated that those sites could be net $\mathrm{CH}_{4}$ sources. At the global scale, plant-based $\mathrm{CH}_{4}$ emissions has been estimated to contribute up to $22 \%$ of the total global flux (Carmichael et al., 2014), but the role of trees in global $\mathrm{N}_{2} \mathrm{O}$ budgets remains unknown. Currently, tree density at the global scale is estimated at $c a .3 .04$ trillion (Crowther et al., 2015), hence, it is plausible to assume that even if we measure low stem emissions at the site-scale, these could possibly upscale to a larger flux at the global scale.

\subsection{Outlook}

Our study highlights the increasing importance of including tree-mediated fluxes in trace gas budgets, with implications for refining ecosystem-scale estimates, as well as global greenhouse gas budgets. The results show for the first time that $\mathrm{N}_{2} \mathrm{O}$ and $\mathrm{CH}_{4}$ emissions from tree stems on well-drained soils are apparently widespread and detectable in many tropical trees in Africa. These findings emphasize the need for additional studies on tree stem fluxes in order to better quantify stem flux magnitudes and their mechanisms. Efforts should be concentrated on measuring fluxes at different stem heights (especially near the base of the tree wherever possible), among several diameter sizes, and for long periods (such as employed in this study). The primacy of the African continent in global climate dynamics is unquestionable, yet, our understanding of the contribution of the continent to global greenhouse gas budgets is still characterised by high uncertainty. Concurrent measurements of soil and stem greenhouse gas fluxes from different regions, soil types and land uses as well as their controlling factors is crucial for a rigorous understanding of Africa's greenhouse gas balance. Presently, close to half of the available studies on trace gas fluxes in Africa are from laboratory incubations, but these often do not capture the high spatial and temporal variability that drive in situ fluxes. Most of 
the few remaining studies that were conducted in the field are also limited by their short measuring campaigns and lack of replications with independent plots. Such as employed in this study, further approaches should additionally focus on collecting data over longer periods and over sufficient spatial replications.

\subsection{References}

Carmichael, M. J., Bernhardt, E. S., Bräuer, S. L., \& Smith, W. K. (2014). The role of vegetation in methane flux to the atmosphere: should vegetation be included as a distinct category in the global methane budget? Biogeochemistry, 119(1), 1-24. https://doi.org/10.1007/s10533-014-9974-1

Corre, M. D., Pennock, D. J., Van Kessel, C., \& Elliott, D. K. (1999). Estimation of annual nitrous oxide emissions from a transitional grassland-forest region in Saskatchewan, Canada. Biogeochemistry, 44(1), 29-49. https://doi.org/10.1023/A:1006025907180

Crowther, T. W., Glick, H. B., Covey, K. R., Bettigole, C., Maynard, D. S., Thomas, S. M., et al. (2015). Mapping tree density at a global scale. Nature, 525(7568), 201-205. https://doi.org/10.1038/nature14967

Huang, J., Golombeck, A., Prinn, R. G., Weiss, R. F., Fraser, P. J., Simmonds, P., et al. (2008). Estimation of regional emissions of nitrous oxide from 1997 to 2005 using multinetwork measurements, a chemical transport model, and an inverse method. Journal of Geophysical Research Atmospheres, 113(17), 1-19. https://doi.org/10.1029/2007JD009381

Kim, D. G., Thomas, A. D., Pelster, D. E., Rosenstock, T. S., \& Sanz-Cobena, A. (2016). Greenhouse gas emissions from natural ecosystems and agricultural lands in sub-Saharan Africa: Synthesis of available data and suggestions for further research. Biogeosciences, 13(16), 4789-4809. https://doi.org/10.5194/bg-13-4789-2016

Pitz, S. L., \& Megonigal, J. P. (2017). Temperate forest methane sink diminished by tree emissions. New Phytologist, 214(4), 1432-1439. https://doi.org/10.1111/nph.14559

Saunois, M., Bousquet, P., Poulter, B., Peregon, A., Ciais, P., Canadell, J. G., et al. (2016). The global methane budget 2000-2012. Earth System Science Data, 8(2), 697-751. https://doi.org/10.5194/essd-8-697-2016 
Schimel, D. S., \& Potter, C. S. (1995). Process modelling and spatial extrapolation. In P. A. Matson \& R. C. Harriss (Eds.), Biogenic Trace Gases: Measuring Emissions from Soil and Water (pp. 358-383). Cambridge, Massachusetts: Blackwell Sci Publication.

Shoemaker, J. K., Keenan, T. F., Hollinger, D. Y., \& Richardson, A. D. (2014). Forest ecosystem changes from annual methane source to sink depending on late summer water balance. Geophysical Research Letters, 41(2), 673-679. https://doi.org/10.1002/ 2013GL058691

Thompson, R. L., Chevallier, F., Crotwell, A. M., Dutton, G., Langenfelds, R. L., Prinn, R. G., et al. (2014). Nitrous oxide emissions 1999 to 2009 from a global atmospheric inversion. Atmospheric Chemistry and Physics, 14(4), 1801-1817. https://doi.org/10.5194/acp-14-1801-2014

Tian, H., Lu, C., Ciais, P., Michalak, A. M., Canadell, J. G., Saikawa, E., et al. (2016). The terrestrial biosphere as a net source of greenhouse gases to the atmosphere. Nature, 531(7593), 225-228. https://doi.org/10.1038/nature16946

Valentini, R., Arneth, A., Bombelli, A., Castaldi, S., Cazzolla Gatti, R., Chevallier, F., et al. (2014). A full greenhouse gases budget of africa: Synthesis, uncertainties, and vulnerabilities. Biogeosciences, 11(2), 381-407. https://doi.org/10.5194/bg-11-381-2014

Welch, B., Gauci, V., \& Sayer, E. J. (2019). Tree stem bases are sources of CH4 and N2O in a tropical forest on upland soil during the dry to wet season transition. Global Change Biology, 25(1), 361-372. https://doi.org/10.1111/gcb.14498

Wen, Y., Corre, M. D., Rachow, C., Chen, L., \& Veldkamp, E. (2017). Nitrous oxide emissions from stems of alder, beech and spruce in a temperate forest. Plant Soil. https://doi.org/10.1007/s11104-017-3416-5

Werner, C., Butterbach-Bahl, K., Haas, E., Hickler, T., \& Kiese, R. (2007). A global inventory of $\mathrm{N} 2 \mathrm{O}$ emissions from tropical rainforest soils using a detailed biogeochemical model. Global Biogeochemical Cycles, 21(3). https://doi.org/10.1029/2006GB002909 


\section{ACKNOWLEDGEMENT}

\section{Alhamdulillah!}

I am very grateful to the German Research Foundation who provided the funding for my $\mathrm{PhD}$ research.

We are only as sturdy as the shoulders we stand upon, and I was fortunate enough to stand atop two brilliant and supportive ones. I am forever indebted to my PhD supervisor, Professor Dr. Edzo Veldkamp for accepting me into his working group, from the masters' level all through my $\mathrm{PhD}$, and for his continuous confidence in me. Ed, your encouraging attitude and emails for a job well done made me feel more confident in myself and in my work. Your door was always open with a warm smile when I had a problem or question, and you created an intellectually stimulating yet informal work culture that made me feel so much at ease to express myself as a scientist. Thank you for been supportive and encouraging on my strides and setbacks.

To Dr. Marife Corre, my co-supervisor: I am grateful to God that you took a chance on me during our bioclimatology class seminar, and I value every opportunity to learn from you. Your enthusiasm and passion for knowledge sharing and good research is both contagious and motivational for me. You have been my primary resource in learning and building scientific expertise. It was your critical feedbacks, several hours of engaged discussions and teaching, selfless acts of kindness, understanding and encouragement that fuelled my stride to the finish line. You remain my role model for a scientist and a mentor, and I hope to emulate your sharp intellect.

I am sincerely grateful to my thesis committee members: Professor Dr. Alexander Knohl for making time to come to my presentations, for the numerous discussions and for his insightful comments and feedbacks; and to Dr. Guntars Martinson for his constructive feedback during my thesis committee meetings. Special thanks to Professor Dr. Klaus Dittert for joining my examination committee, especially considering the circumstances we are in, and for engaging with my $\mathrm{PhD}$ viva and making the process a happy experience.

My fieldwork would not have been possible without the continuous effort of Dr. Oliver van Straaten. Among many other things, he coordinated the safe transport of research equipment to Cameroon, assisted with site selections, and was always available to assist me when I had questions in the field. His expertise, supervision and friendship during my difficult moments contributed immensely to the successful completion of my $\mathrm{PhD}$. 
Sharing an office with Rodine Tchiofo and Raphael Manu has been one of the highlights of my PhD studies. We had many laughs, regular and constructive discussions, and I benefitted tremendously from their expertise. I am thankful to Rodine, who showed me what an ideal doctoral student looks like with her inspiring work ethic. To Raphael and Belinda, for their lovely home, hospitality and good food that has been my source of comfort in Germany, during good times and difficult ones.

The Department of Soil Science of Tropical and Subtropical Ecosystems has been a source of friendships, support and collaboration. Special thanks to Joost and Greta, for their immense help when my mama was ill, for the many discussions we had, and for all the good laughs; to Xenia, for translating my abstract and sharing the office with me on weekends; to Marcus, for all his R tutorials; to Andrea, for been so kind to me; to Kerstin, Martina, Andrea, Dirk, and Lars for their assistance with laboratory analyses; and to Cecille, Jie, Guodong, Guan-tao, Dan, Lukas and Leonie, for the friendships. I am sincerely grateful to the department for their support during my time of need. Many thanks.

I gratefully acknowledge our counterparts in Cameroon, the International Institute for Tropical Agriculture (IITA) for granting us access and use of their storage facilities, and for other logistical support.

I am especially grateful to my field assistant and friend Leonel Boris Gadjui Youatou, for assisting in the coordination of the project. He was hardworking, trustworthy, and extremely dedicated to practicing good science. Many thanks to Narcis Lekeng, Yannick Eyenga Alfred, Denis Djiyo and all the other field workers for their tireless effort in the field, often under very difficult conditions. I also thank Walther Pohl for helping to transport research equipment to Cameroon and for assisting with site selections.

My heartfelt gratitude goes to my friends: Dr. Issaka Abdulai and his wonderful family for their support and kindness; Grace Cudjoe for her constant support; Divine Torkutsah, Abdul Latif Moudassirrou, Osei-Wusu Emmanuel and Teddy Freduah Agyemang for simply been there for me; Sheikh Bawa Aransa Awuze for all his advice and prayers; and Aastha Tyagi for the good laughs and company. Parisa Mazinanian deserves special thanks for her immense support and encouragement, I could not have done this without her; Hakuna Matata Parpar :)

Lastly, I would like to thank my family for all their unwavering support and love. I am especially grateful to my Parents, Iddris Issah and Rabiatu Umar for putting aside their dreams so I can achieve my mine, JazākumAllāhu Khayran. You are the best there ever was. 


\section{THESIS DECLARATION}

I, Najeeb Al-Amin Iddris, hereby declare that I have composed the present thesis independently using no other sources and resources than those stated. In particular, I have completed all parts of the thesis myself; I have neither, nor will I, accept unauthorised outside assistance either free of charge or subject to a fee.

I furthermore declare that this work has not been submitted elsewhere in any form as part of another thesis procedure.

Göttingen, March 2020

(Najeeb Al-Amin Iddris) 